\title{
Comparative Study of Ground-Water Quality, 1976 and 1996, and Initial Gain-and-Loss Assessment of Boulder Creek, Boulder County, Colorado
}

By Breton W. Bruce, U.S. Geological Survey and Christopher O'Riley, City of Boulder, Colorado

U.S. GEOLOGICAL SURVEY

Water-Resources Investigations Report 97-4091

Prepared in cooperation with the BOULDER COUNTY HEALTH DEPARTMENT, and the CITY OF BOULDER, COLORADO

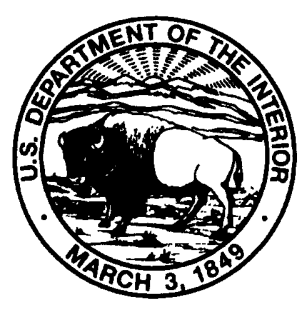




\section{U.S. DEPARTMENT OF THE INTERIOR \\ BRUCE BABBITT, Secretary}

\section{U.S. GEOLOGICAL SURVEY}

Gordon P. Eaton, Director

The use of firm, trade, and brand names in this report is for identification purposes only and does not constitute endorsement by the U.S. Geological Survey.

For additional information write to:

District Chief

U.S. Geological Survey

Box 25046, Mail Stop 415

Denver Federal Center

Denver, CO 80225-0046
Copies of this report can be purchased from:

U.S. Geological Survey

Branch of Information Services

Box 25286

Denver, CO 80225-0286 


\section{CONTENTS}

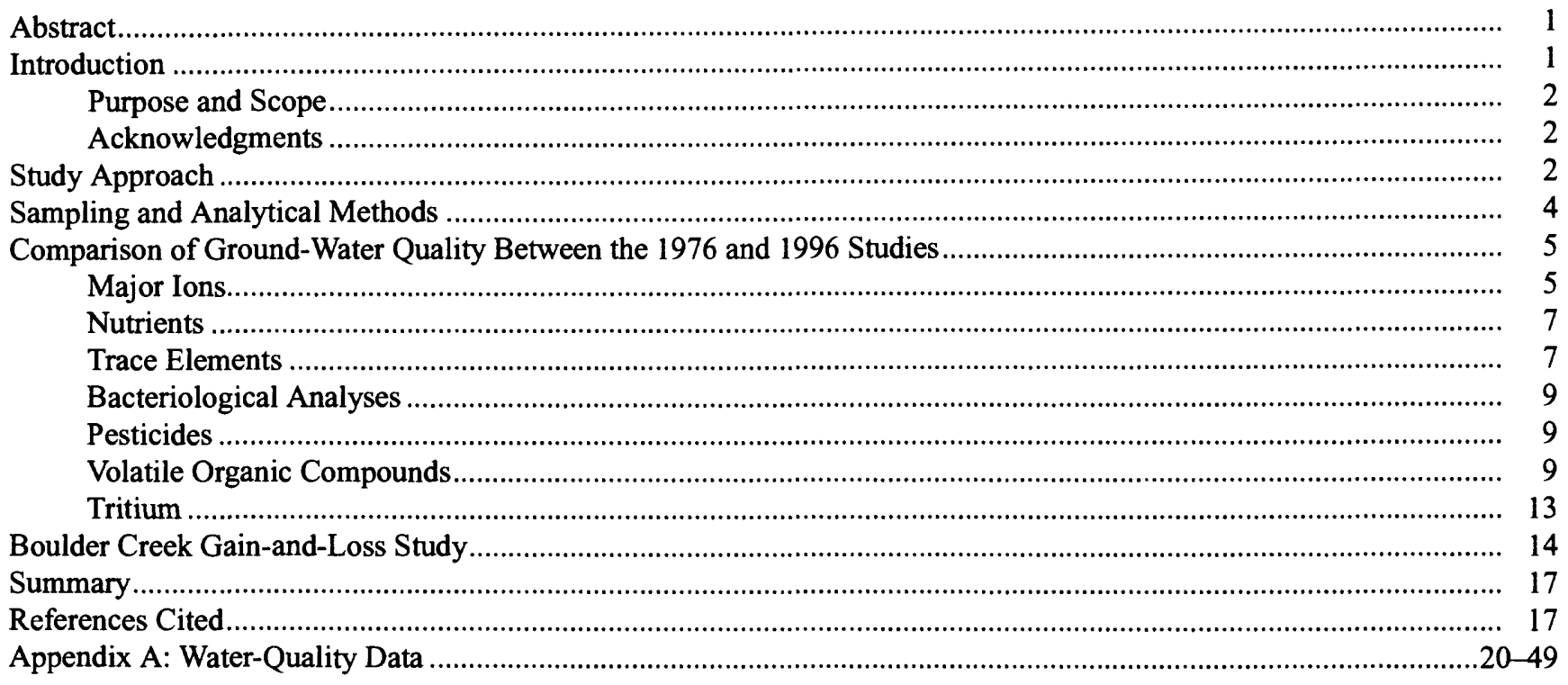

\section{FIGURES}

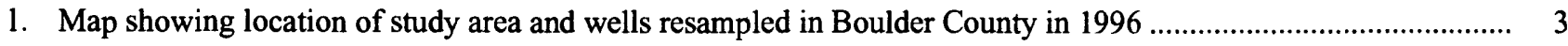

2. Box plots showing dissolved-solids concentrations in ground-water samples collected during the 1976 and 1996 studies in Boulder County

3. Graph showing percent change in median concentration of selected dissolved ions in Boulder County ground water between 1976 and 1996

4. Scatter diagram showing paired chloride concentrations for wells sampled in 1976 and 1996 in Boulder County.....

5. Box plots showing nitrite plus nitrate, as nitrogen, concentrations for wells sampled in 1976 and 1996 in Boulder County.

6. Box plots showing nitrite plus nitrate, as nitrogen, concentrations for wells sampled in 1976 and 1996 in the $A$. mountain and $B$. plains settings in Boulder County .

7. Graph showing comparison of median concentrations for plumbing-related metals from wells sampled in 1976 and 1996 in Boulder County.

8. Map showing location of Boulder Creek surface-water gain-and-loss study and discharge-measurement sites, October 24, 1996.

9. Graph showing residual discharge from a water mass balance on Boulder Creek.

\section{TABLES}

1. Analytical method reporting limits, by year, for determinations of inorganic water-quality constituents

2. Minimum, maximum, and median concentrations of selected constituents for wells sampled in 1976 and 1996 in Boulder County.....

3. Results of coliform bacteria analyses for wells sampled in 1976 and 1996 in Boulder County..

4. Pesticide compounds analyzed for wells sampled in 1996 in Boulder County

5. Concentrations and maximum contaminant levels for pesticide compounds detected in wells sampled in 1996 in Boulder County

Volatile organic compounds (VOC's) analyzed for wells sampled in 1996 in Boulder County.....

7. Concentrations and maximum contaminant levels of volatile organic compounds detected in wells sampled in 1996 in Boulder County.....

8. Data used to calculate a surface-water flow mass balance for gain-and-loss study performed on 
CONVERSION FACTORS AND ABBREVIATIONS

\begin{tabular}{rll}
\hline Multiply & By & To obtain \\
\hline & & \\
cubic foot per second $\left(\mathrm{ft}^{3} / \mathrm{s}\right)$ & 0.02832 & cubic meter per second \\
foot $(\mathrm{ft})$ & 0.3048 & meter \\
micrometer $(\mu \mathrm{m})$ & $3.937 \times 10^{-5}$ & inch \\
mile $(\mathrm{mi})$ & 1.609 & kilometer \\
picocurie per liter $(\mathrm{pCi} / \mathrm{L})$ & 0.3125 & tritium units $(\mathrm{TU})$ \\
\hline
\end{tabular}

Degree Celsius $\left({ }^{\circ} \mathrm{C}\right)$ may be converted to degree Fahrenheit $\left({ }^{\circ} \mathrm{F}\right)$ by using the following equation:

$$
{ }^{\circ} \mathrm{F}=9 / 5\left({ }^{\circ} \mathrm{C}\right)+32 \text {. }
$$

\section{ACRONYMS AND ADDITIONAL ABBREVIATIONS:}

maximum contaminant level (MCL)

microgram per liter $(\mu \mathrm{g} / \mathrm{L})$

milligram per liter $(\mathrm{mg} / \mathrm{L})$

milliliter $(\mathrm{mL})$

method reporting limit (MRL)

U.S. Geological Survey National Water-Quality Laboratory (NWQL)

secondary maximum contaminant level (SMCL)

Sea level: In this report "sea level" refers to the National Geodetic Vertical Datum of 1929 (NGVD of 1929)—a geodetic datum derived from a general adjustment of the first-order level nets of both the United States and Canada, formerly called Sea Level Datum of 1929. 


\title{
Comparative Study of Ground-Water Quality, 1976 and1996, and Initial Gain-and-Loss Assessment of Boulder Creek, Boulder County, Colorado
}

\author{
By Breton W. Bruce and Christopher O'Riley
}

\begin{abstract}
From 1975 through 1977, the U.S. Geological Survey, in cooperation with the Boulder County Health Department and the Colorado Geological Survey, sampled numerous surfacewater and ground-water sites throughout Boulder County, Colorado. In 1996, the U.S. Geological Survey, in cooperation with the Boulder County Health Department and the City of Boulder, identified and resampled 30 of the same wells sampled in the earlier study. Data from the two study periods are compared in this report.
\end{abstract}

The range and median concentrations of dissolved solids in the samples were very similar between the two study periods; however, the median concentration of sulfate decreased significantly in the 1996 study compared to the 1975-77 study, and the median concentration of chloride increased. Overall, nitrate concentrations were less in 1996, though, if considering only wells in the mountainous part of Boulder County, there was an apparent increase in nitrate concentrations in the 1996 study. Nitrate concentrations for wells in the plains part of the study area decreased significantly in the 1996 study.

Comparison of trace-element concentrations was problematic owing to the limited number of constituents measured in the 1975-77 study, changes in analytical method reporting limits, and possible differences in sampling techniques. Coliform bacteria were detected in 8 of 29 samples collected in 1996 compared to only one detection in the 1975-77 study. Pesticides and volatile organic compounds were analyzed during the 1996 study but not in the 1975-77 study. Several pesticides and volatile organic compounds were detected; all detections were in samples from the plains part of Boulder County.

A surface-water gain-and-loss study was done on October 24, 1996, to quantify the volume of water exchange between the surface-water and ground-water systems along the urban reach of Boulder Creek. Overall, the stream reach had a net gain in surface-water flow, with the majority of ground-water discharge to the stream occurring in downstream segments.

\section{INTRODUCTION}

Rapid growth along the eastern edge of the Rocky Mountains in Colorado has caused concern about the effect on water supply and water quality in the Front Range mountain communities and the Front Range urban corridor on the plains. It is generally accepted that the overlying land use can have direct effects on the quality of ground water and that ground water eventually discharges to surface-water streams and lakes. Consequently, surface-water quality is related to the quality of discharging ground water and overland runoff. Only recently have networks of wells been established to monitor trends in ground-water quality. Very little historical data are available that describe broad-scale ground-water quality in Colorado. Boulder County, Colo., is one exception. From July 1975 through July 1977, the U.S. Geological Survey (USGS), in cooperation with the Boulder County Health Department and the Colorado Geological Survey, performed a comprehensive 
water-resources investigation of Boulder County, which included water-quality sampling of 102 wells, 9 springs, and 34 stream sites (Hall and others, 1979).

In 1996, the USGS, in cooperation with the Boulder County Health Department and the City of Boulder, located and resampled 30 of the same wells sampled in the 1975-77 water-quality study. This was done to compare water quality from the two study periods and to indicate differences between the two water-quality data sets collected about 20 years apart. Most of the wells are within the Boulder Creek drainage basin, which is the primary source of drinking water for the City of Boulder. The wells are a combination of private drinking-water wells and domestic wells primarily used for lawn irrigation.

It was recognized at the outset of the 1996 study that one water sample from a well does not necessarily describe the ambient water quality for that location. Only regular sampling over extended time periods (for example, 1 year or more) can begin to assess the overall trends in ground-water quality. Therefore, it would not be valid to identify trends in water quality on the basis of a comparison of analytical results from two sampling events in a single well. However, a statistically significant change in the median concentration of a single dissolved constituent for the entire population of 30 wells sampled in the two study periods is a more meaningful indication of a long-term trend in ground-water quality for the study area.

\section{Purpose and Scope}

This report presents the water-quality data collected during 1975-77 and 1996 and the statistically significant differences between the data sets where appropriate. This report also lists the results of analyses for anthropogenic constituents that were not measured during the 1975-77 study, hereinafter identified by the year 1976. Additionally, this report presents the measured data and calculated results of a streamflow gain-and-loss study in Boulder Creek through the urban corridor of the City of Boulder on October 24, 1996. This part of the study indicates stream segments that were gaining or losing flow volume through a hydrologic connection with the adjacent ground-water system. The gain-and-loss study was undertaken to demonstrate the value of this tool for quantifying ground-water/surface-water interactions.

\section{Acknowledgments}

The authors thank the numerous property owners who altered their schedules and made their wells available for sampling. The Boulder County Open Space Department was particularly helpful allowing access to wells on county property and acreage bordering Boulder Creek during the surfacewater gain-and-loss study. Special thanks go to Ann Lukens of the Boulder County Health Department for her assistance in the field and with analysis and interpretation of the coliform bacteria samples, and to Brad Austin of the Colorado Department of Public Health and Environment for arranging the collection and analysis of pesticide samples in cooperation with the Colorado Department of Agriculture.

\section{STUDY APPROACH}

Initially, the wells targeted for resampling were chosen from Hall and others (1979) by a committee that included representatives from the USGS, Boulder County Health Department, and the City of Boulder. The wells selected were broadly distributed predominantly across the Boulder Creek drainage basin but focused on areas that were densely populated or had undergone substantial land-use changes during the last 20 years. Areas of substantial land-use change were identified by knowledgeable representatives from the cooperating agencies. Some wells initially selected no longer existed, or permission to sample could not be obtained. An iterative process led to the identification of 30 wells that had been sampled previously, and permission was obtained from the owners to resample them. The locations of the 30 wells sampled in 1996 are shown in figure 1. All wells had been sampled previously for a broad range of water-quality constituents including major ions, nutrients, trace elements, and coliform bacteria. In addition to these constituents, sampling during the 1996 study included pesticides, volatile organic compounds (VOC's, including some gasoline and fuel oil components, industrial solvents, and chlorination by-products), and several analyses for tritium, which can be used as a ground-water age-dating tool. All analyses were performed at the USGS National Water-Quality Laboratory (NWQL) in Arvada, Colo., with the exception of the bacteriological determinations performed by the Boulder County Health Department. 




Figure 1. Location of study area and wells resampled in Boulder County in 1996.

Additionally, the Colorado Department of Public Health and Environment and the Colorado Department of Agriculture participated in the 1996 study by supplying pesticide analyses on all water samples. The pesticide analyses were done at the Colorado Department of Agriculture's laboratory in Denver, Colo.

A streamflow gain-and-loss study also was performed during the 1996 study period (October 24, 1996). This study focused on Boulder Creek from the mouth of Boulder Canyon (to the west) downstream through the City of Boulder to a point just upstream from the effluent discharge from the 75th Street wastewater-treatment plant (to the east). Discharge measurements were made on the main stem of Boulder Creek, and all major surface-water diversions and inflows to the creek were quantified. A mass balance of water volume in the stream was calculated, and any missing or excess water in the creek was attributed to a gain from or loss to ground water by the stream.

This report presents the results from the 1976 and the 1996 studies for all 30 wells sampled. Comparisons of the range and median concentrations for several constituents from both data sets are provided. VOC and pesticide detections are listed, and a summary of the tritium analyses is presented. Also presented are the results of the surface-water gain-andloss study indicating the results of the mass balance calculations for each stream segment evaluated in Boulder Creek. 


\section{SAMPLING AND ANALYTICAL METHODS}

Wells were sampled using the existing pumping systems, if possible, or by using a portable peristaltic pump. Where the existing pumping system was used, water was collected from an in-line access point as close to the well head as possible, usually at the drain valve at the base of the pressure tank. Wells initially were purged at the maximum rate possible through a standard garden hose. The flow then was split by diverting a small amount of water through a clean polyethylene tube to an enclosed flow-through chamber where $\mathrm{pH}$, temperature, dissolved oxygen, and specific conductance were monitored. Once these measurements were stable (three similar readings at 5-minute intervals), water was collected for analysis. Filtered samples were passed through a $0.45-\mu \mathrm{m}$ disposable capsule filter. Samples for nutrient, bacteria, pesticide, and VOC analyses were stored on ice until delivered to the laboratory. Samples for cation and trace-element analyses were preserved with 1 milliliter $(\mathrm{mL})$ concentrated nitric acid $\left(\mathrm{HNO}_{3}\right)$. Samples for VOC analyses were preserved with 2-3 drops of concentrated hydrochloric acid $(\mathrm{HCl})$.
Samples for coliform bacteria analyses were delivered to the Boulder County Health Department at the end of each sampling day and were immediately processed.

Though most analyses compared in this report were performed at the USGS NWQL, analytical methodology has changed substantially between 1976 and 1996. Consequently, analytical sensitivity and method reporting limits (MRL's) also have changed. The MRL's for the analyzed inorganic constituents common to both studies are listed in table 1. For the purposes of data comparison in this report, nondetections have been set to a value of 0 . No data comparisons have been made where results have large differences in MRL's or where a data set has numerous nondetections.

No records exist that detail the sampling technique used in the 1976 study. It was anticipated that different approaches to sample collection might affect analytical results. A listing of the analytical results for inorganic constituents from both studies is provided in Appendix A at the back of this report. The results for analyses of coliform bacteria, pesticides, and VOC's are listed in separate tables within the body of the report.

Table 1. Analytical method reporting limits, by year, for determinations of inorganic water-quality constituents

[Analyses performed at USGS National Water-Quality Laboratory, Arvada, Colorado; --, not measured; ?, could not ascertain]

\begin{tabular}{|c|c|c|c|c|c|c|c|c|}
\hline Constituent & 1976 & 1996 & Constltuent & 1976 & 1996 & Constituent & 1976 & 1996 \\
\hline \multicolumn{9}{|c|}{ Major ions (in milligrams per liter) } \\
\hline Calcium & $0.1^{*}$ & 0.02 & Magnesium & $0.1^{*}$ & 0.01 & Sodium & $0.1^{*}$ & 0.2 \\
\hline Fluoride & $0.1^{*}$ & 0.1 & Silica & $0.1^{*}$ & 0.01 & & & \\
\hline \multicolumn{9}{|c|}{$\begin{array}{l}\text { Nutrients (in milligrams per liter) } \\
\text { |nitrogen species as } \mathrm{N} \text {; phosphate as } \mathrm{PO}_{\mathbf{4}} \text { | }\end{array}$} \\
\hline $\begin{array}{l}\text { Nitrite plus } \\
\text { nitrate }\end{array}$ & $0.1^{*}$ & 0.1 & Phosphorus & -- & 0.01 & Orthophosphate & 0.03 & 0.03 \\
\hline \multicolumn{9}{|c|}{ Trace elements (in micrograms per liter) } \\
\hline Arsenic & 1 & 1 & Barium & 100 & 1 & Beryllium & -- & 1 \\
\hline Silver & -- & 1 & Zinc & 20 & 1 & Antimony & -- & 1 \\
\hline Aluminum & -- & 1 & Selenium & 1 & 1 & Uranium & $?$ & 1 \\
\hline
\end{tabular}

${ }^{*}$ Method reporting limits from Skougstad and others, 1979. 


\section{COMPARISON OF GROUND-WATER QUALITY BETWEEN THE 1976 AND 1996 STUDIES}

\section{Major lons}

Major ions in water samples are constituents that generally make up the bulk of the total dissolved species in water and include calcium $(\mathrm{Ca})$, magnesium $(\mathrm{Mg})$, sodium $(\mathrm{Na})$, potassium $(\mathrm{K})$, chloride $(\mathrm{Cl})$, sulfate $\left(\mathrm{SO}_{4}\right)$, fluoride $(\mathrm{F})$, and bicarbonate $\left(\mathrm{HCO}_{3}\right)$, which generally is the primary component of alkalinity. Alkalinity is reported as calcium carbonate $\left(\mathrm{CaCO}_{3}\right)$. Concentrations of major ions dissolved in ground water often result from natural processes such as rock/water interactions; however, human activities also can affect the concentrations of these constituents. An example would be the application of road salt producing increased chloride concentrations in nearby ground water. The minimum, maximum, and median concentrations for the major ions measured in ground water during the 1976 and 1996 studies are listed in table 2 .

The concentration of the sum of dissolved solids in a water sample is a general indicator of water quality. Dissolved-solids concentrations are calculated from the total concentrations of measured major ions. The U.S. Environmental Protection Agency (USEPA) has set a national secondary maximum contaminant level (SMCL) for dissolved solids in drinking water of $500 \mathrm{mg} / \mathrm{L}$ (U.S. Environmental Protection Agency, 1996). Median concentrations for dissolved solids during the 1976 and 1996 studies were 486 and $523 \mathrm{mg} / \mathrm{L}$, respectively (fig. 2). When compared statistically using the Wilcoxon signed-rank test (Helsel and Hirsch, 1995, p. 142-147) at the 95-percent

Table 2. Minimum, maximum, and median concentrations of selected constituents for wells sampled in 1976 and 1996 in Boulder County

[Concentrations in milligrams per liter, except as noted; Min, minimum concentration; Max, maximum concentration; Med, median concentration;

$<$, less than; NA, not available; n/a, not applicable; *SMCL, secondary maximum contaminant level; *MCL, maximum contaminant level]

\begin{tabular}{|c|c|c|c|c|c|c|c|}
\hline \multirow{2}{*}{ Constituent } & \multicolumn{3}{|c|}{ Sampled $1975-77^{1}$} & \multicolumn{3}{|c|}{ Sampied 1996} & \multirow{2}{*}{ SMCL } \\
\hline & Min & $\operatorname{Max}$ & Med & Min & Max & Med & \\
\hline \multicolumn{8}{|c|}{ Major Ions } \\
\hline pH-laboratory (standard units) & NA & NA & NA & 6.6 & 8.4 & 7.2 & $6.5-8.5$ \\
\hline Hardness & 15.2 & 1,952 & 270 & 11 & 220 & 245 & $\mathrm{n} / \mathrm{a}$ \\
\hline Calcium & 4.1 & 560 & 65.5 & 2.7 & 580 & 66 & $\mathrm{n} / \mathrm{a}$ \\
\hline Magnesium & 1.2 & 280 & 23.5 & 0.91 & 360 & 19.5 & $\mathrm{n} / \mathrm{a}$ \\
\hline Sodium & 2.5 & 480 & 39.5 & 1.5 & 350 & 33.5 & $\mathrm{n} / \mathbf{a}$ \\
\hline Potassium & 0.7 & 15 & 2.4 & 0.5 & 15 & 2.2 & $\mathrm{n} / \mathbf{a}$ \\
\hline Chloride & 0.8 & 42 & 10.3 & 0.4 & 150 & 15.5 & 250 \\
\hline Sulfate & 7.1 & 1,700 & 92 & 2.6 & 2,000 & 49 & 250 \\
\hline Fluoride & 0.2 & 43 & 0.55 & 0.1 & 4 & 0.65 & 2.0 \\
\hline Silica & 9 & 31 & 15 & 7.3 & 37 & 15 & $\mathrm{n} / \mathrm{a}$ \\
\hline Sum of dissolved solids & 80 & 2,907 & 486 & 33 & 3,140 & 523 & 500 \\
\hline Bromide & NA & NA & NA & $<0.01$ & 4.4 & 0.12 & $n / a$ \\
\hline Specific conductance & 120 & 3,500 & 795 & 52 & 3,400 & 870 & $n / a$ \\
\hline Alkalinity & 32 & 1,030 & 248 & 21 & 762 & 242 & $\mathrm{n} / \mathrm{a}$ \\
\hline \multicolumn{8}{|c|}{$\begin{array}{l}\text { Nutrients } \\
\text { |nitrogen species as N; orthophosphate as } \mathrm{PO}_{4} \mid\end{array}$} \\
\hline Nitrite & $<0.01$ & 0.05 & $<0.01$ & $<0.01$ & 0.05 & $<0.01$ & 1 (MCL) \\
\hline Nitrite plus nitrate & 0.06 & 14 & 0.92 & 0.05 & 11 & 0.37 & $10(\mathrm{MCL})$ \\
\hline Orthophosphate & $<0.03$ & 2.27 & 0.03 & $<0.03$ & 0.58 & 0.05 & $\mathrm{n} / \mathrm{a}$ \\
\hline Phosphorus & NA & NA & NA & $<0.01$ & 0.49 & $<0.01$ & $\mathbf{n} / \mathbf{a}$ \\
\hline
\end{tabular}

*From U.S. Environmental Protection Agency (1996).

${ }^{1}$ From Hall and others (1979). 


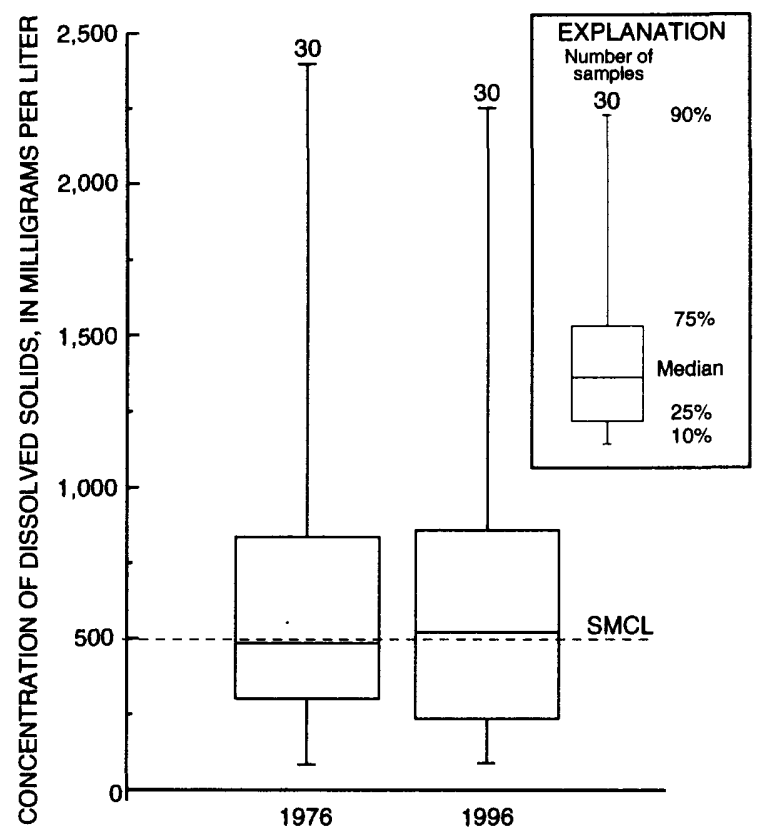

Figure 2. Dissolved-solids concentrations in ground-water samples collected during the 1976 and 1996 studies in Boulder County.

confidence interval, there was no significant difference ( $p>0.05$ ) in the median concentrations for dissolved solids between the 1976 and 1996 studies. The median dissolved-solids concentrations calculated for wells in the mountainous part of Boulder County (1976 = $236 \mathrm{mg} / \mathrm{L} ; 1996=244 \mathrm{mg} / \mathrm{L})$ were lower than those for wells in the plains $(1976=623 \mathrm{mg} / \mathrm{L} ; 1996=$ $578 \mathrm{mg} / \mathrm{L}$ ); but, the median concentrations were very similar between the two study periods within each geographic setting.

There were, however, some substantial differences between 1976 and 1996 in median concentrations for individual major ions that comprise the calculated dissolved-solids concentrations. Whereas there was less than a 10-percent difference in median concentrations of most major ions between the two studies, the median concentration of sulfate decreased 47 percent between the 1976 and 1996 study periods (fig. 3). Sulfate concentration decreased in 20 of 30 paired samples from 1976 to 1996 , and the Wilcoxon signed-rank test indicated a significant difference $(p<0.05)$ in median concentration between the two sulfate data sets. This significant difference in median sulfate concentration could not be assigned to the mountain or to the plains wells and was only significant when all paired data were considered together.

Chloride also showed a large difference in median concentration, increasing about 50 percent

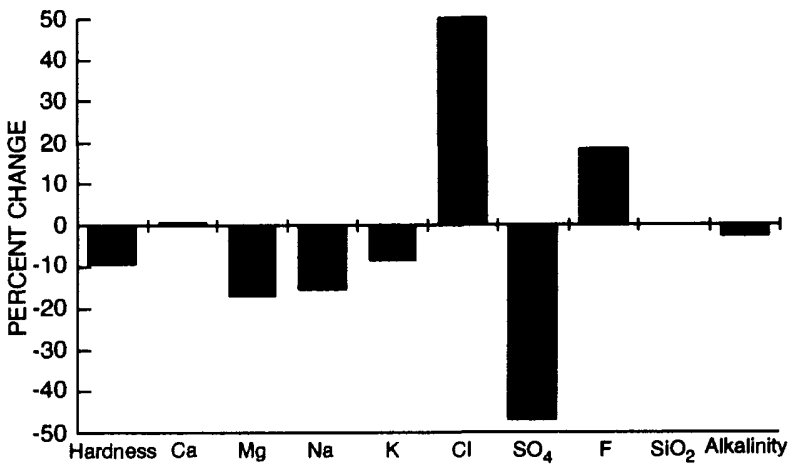

Figure 3. Percent change in median concentration of selected dissolved ions in Boulder County ground water between 1976 and 1996.

from 1976 to 1996. Chloride concentrations for the two study periods, plotted as $x-y$ pairs $(x=1976, y=$ 1996 ), are shown on figure 4. Any pair with identical 1976/1996 concentrations would plot on a 1:1 ratio line. Figure 4 shows many points above the 1:1 ratio line, indicating that the chloride concentration measured in 1996 often was greater than that measured in 1976. This difference in chloride concentration could not be assigned to a statistically significant change in either the mountain or plains wells. Individual wells in both these settings had large increases in chloride concentration.

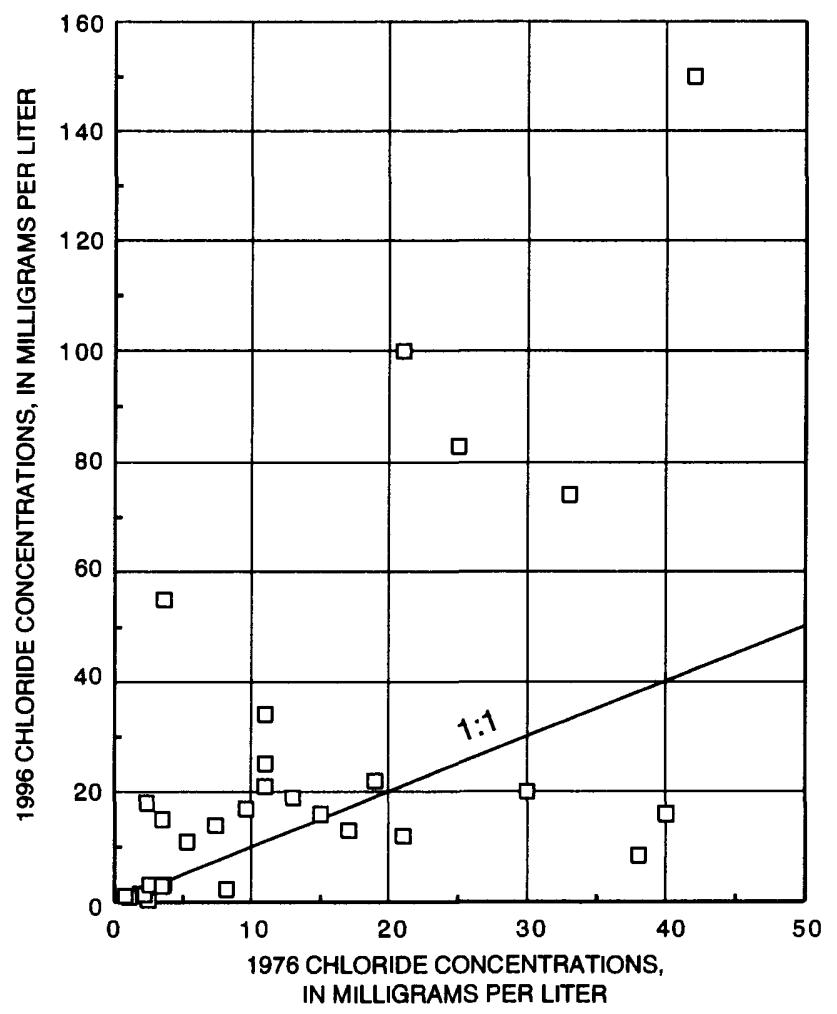

Figure 4. Paired chloride concentrations for wells sampled in 1976 and 1996 in Boulder County. 


\section{Nutrients}

Nutrients include compounds of nitrogen and phosphorus that are important to biological metabolism. Of primary interest as pollutants are the compounds nitrate (associated with sewage and animal waste) and phosphate (associated with detergents and similar products). Each of these compounds can have a significant human source and can affect biomass growth in surface water. High concentrations of nitrate $\left(\mathrm{NO}_{3}\right)$ in drinking water also can result in detrimental human-health effects (U.S. Environmental Protection Agency, 1994). The USEPA has set a national drinking-water maximum contaminant level (MCL) for nitrate at $10 \mathrm{mg} / \mathrm{L}$ as nitrogen (U.S. Environmental Protection Agency, 1996).

Nitrite plus nitrate $\left(\mathrm{NO}_{2}+\mathrm{NO}_{3}\right)$, as nitrogen, was measured in ground water during the 1976 and the 1996 studies. In both sets of data, the concentration of nitrite $\left(\mathrm{NO}_{2}\right)$ was so small (table 2 ) that the results for this analysis will hereinafter be referred to in this text as a nitrate $\left(\mathrm{NO}_{3}\right)$ concentration. Box plots of nitrate concentrations for the 1976 and the 1996 studies are shown in figure 5 . The median concentration of nitrate decreased significantly $(\mathrm{p}<0.05)$ from $0.915 \mathrm{mg} / \mathrm{L}$ in 1976 to $0.365 \mathrm{mg} / \mathrm{L}$ in 1996 . Four samples during the 1976 study had nitrate concentrations exceeding the $1996 \mathrm{MCL}$ of $10 \mathrm{mg} / \mathrm{L}$ nitrate as nitrogen (maximum

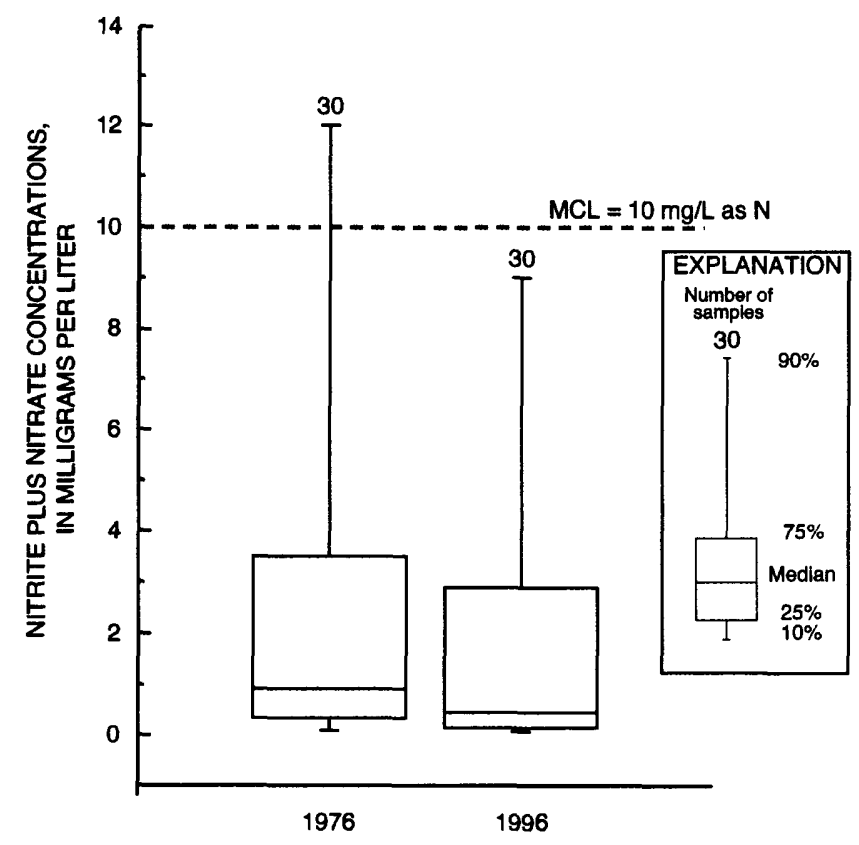

Figure 5. Nitrite plus nitrate, as nitrogen, concentrations for wells sampled in 1976 and 1996 in Boulder County. concentration was $14 \mathrm{mg} / \mathrm{L}$ ). One sample collected during the 1996 study had a nitrate concentration $(11 \mathrm{mg} / \mathrm{L}$ ) larger than the $10-\mathrm{mg} / \mathrm{L} \mathrm{MCL}$.

Box plots showing nitrate concentrations for the 1976 and 1996 studies, divided into mountain (10 wells) and plains ( 20 wells) samples, are shown in figure 6 . Though differences in median nitrate concentrations between the two study periods for the mountain wells (fig. $6 \mathrm{~A}$ ) were not statistically significant $(\mathrm{p}>0.05)$, a slight increase in concentration is suggested by the difference in the 75th-percentile values. The lack of a significant difference in nitrate concentrations for the mountain wells may be an artifact of the small sample size, which limits the statistical discrimination. There was a significant decrease $(p<0.05)$ in nitrate concentrations from 1976 to 1996 for wells sampled in the plains setting.

Concentrations of dissolved phosphorus and orthophosphate generally are low in ground water that is not contaminated. This low concentration mainly is due to the low solubility of most inorganic phosphorus compounds and their use by biota as a nutrient (Hem, 1989 , p. 126). Median concentrations for nutrient species common to the 1976 and the 1996 study periods are listed in table 2 . These data indicate that the concentrations of phosphorus species were low as expected. There was no statistical difference $(\mathrm{p}>0.05)$ between median concentrations of dissolved orthophosphate $\left(\mathrm{PO}_{4}\right)$ between the two studies.

\section{Trace Elements}

Trace elements are a class of constituents, including metals and other inorganics, that generally occur in natural water at trace concentrations less than $1 \mathrm{mg} / \mathrm{L}$. In 1976, 10 trace elements were analyzed in each water sample. Eighteen trace elements were analyzed in the 1996 samples. Comparison of traceelement results between the two study periods was further limited by differences in analytical MRL's. One example of this difference was for barium. The MRL for barium in 1976 was $100 \mu \mathrm{g} / \mathrm{L}$; in 1996 the MRL was $1 \mu \mathrm{g} / \mathrm{L}$. In 1996, 23 of 30 water samples had barium concentrations that were less than $100 \mu \mathrm{g} / \mathrm{L}$. It is not meaningful to compare the median concentration for $1976(<100 \mu \mathrm{g} / \mathrm{L})$ to the median concentration for $1996(44.5 \mu \mathrm{g} / \mathrm{L})$. The MRL's for all trace elements are listed in table 1. 
A.

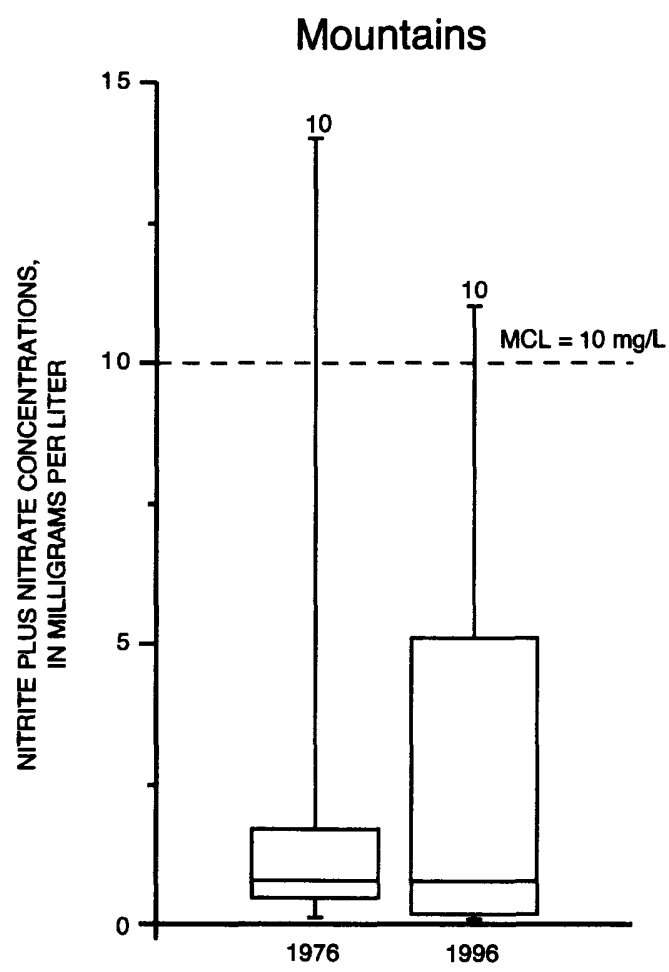

B.

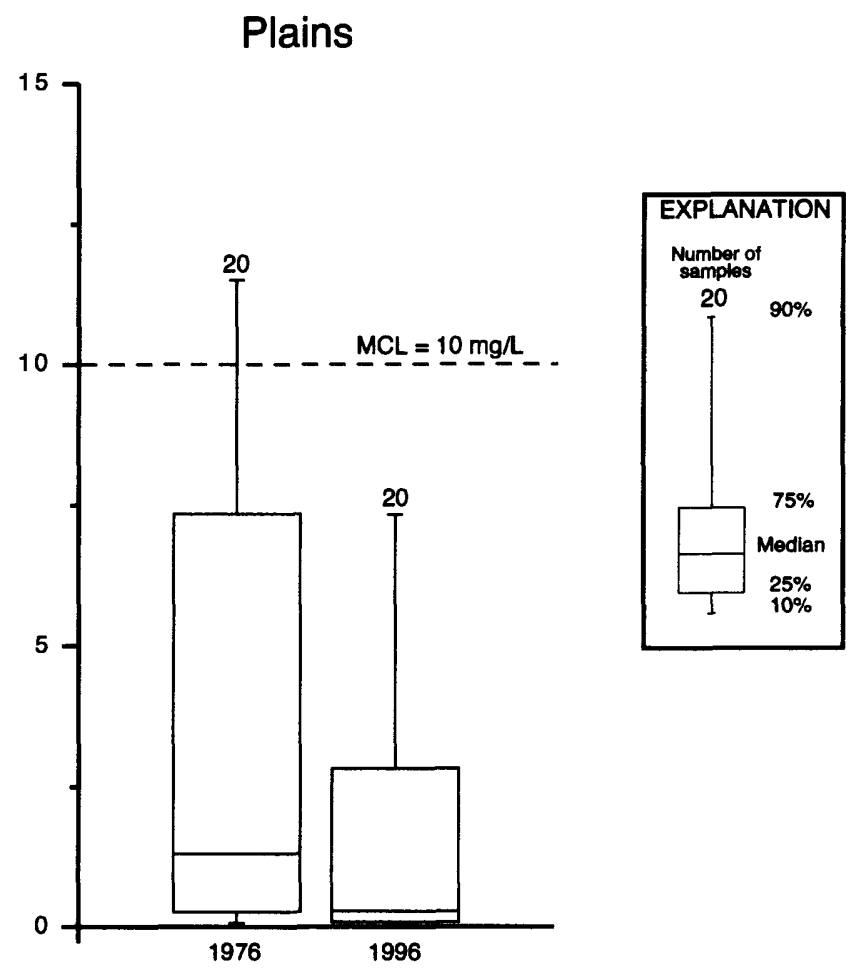

Figure 6. Nitrite plus nitrate, as nitrogen, concentrations for wells sampled in 1976 and 1996 in the A. mountain and $B$. plains settings in Boulder County.

Values reported for other trace-element concentrations may have been affected by sampling technique. No historical description detailing the sampling approach in 1976 is available; however, the few landowners that remembered the 1976 sampling indicated that samples were collected from the inside faucet or outside tap with the easiest access. In 1996, samples were collected as close as possible to the wellhead. Sampling close to the wellhead minimizes the amount of plumbing in contact with the water sample. An example of how the sampling technique might have affected the analytical results of selected constituents is illustrated in figure 7 . The median concentrations from the two study periods for several metals commonly used in well and plumbing materials are shown in figure 7 . These metals all exhibited a decrease in median concentration from 1976 to 1996. The decrease in plumbing-related metal concentrations shown in figure 7 was larger than 70 percent with the exception of lead. However, in 1976, 23 of 30 samples had detectable lead (MRL $=2 \mu \mathrm{g} / \mathrm{L})$; in 1996 only 3 of 30 samples had measurable lead concentrations $(\mathrm{MRL}=1 \mu \mathrm{g} / \mathrm{L})$. The change in sampling technique may explain the decrease in plumbing-related metal concentrations.

By contrast, trace elements that had similar MRL's and that were expected to be derived solely from natural sources (for example, arsenic, molybdenum, selenium, and uranium) exhibited very similar concentrations in 1976 and 1996. Of these constituents, only uranium exhibited elevated concentrations and may be a potential water-quality concern. The USEPA has proposed a drinking-water MCL for uranium of $20 \mu \mathrm{g} / \mathrm{L}$ (U.S. Environmental Protection Agency, 1996). In 1976, 8 of 30 wells had reported uranium analyses. Six of 30 wells in the 1996 sampling exceeded the proposed $20-\mu \mathrm{g} / \mathrm{L} \mathrm{MCL}$ for uranium. Three of these wells were in the mountain setting, and three were in the plains setting. Uranium concentrations in excess of the proposed drinkingwater standard have been measured throughout the South Platte River Basin (Qi and Dennehy, 1997). Should the proposed MCL for uranium be finalized, the use of water with elevated concentrations will be affected. 


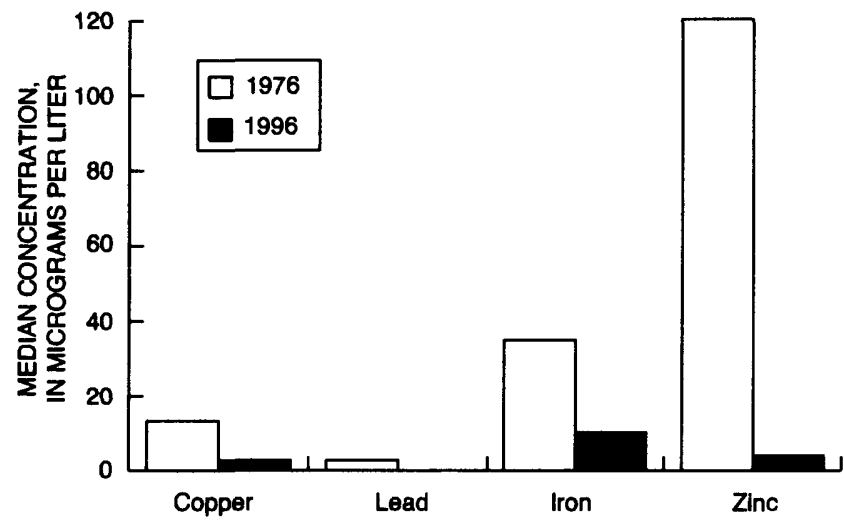

Figure 7. Comparison of median concentrations for plumbing-related metals from wells sampled in 1976 and 1996 in Boulder County.

\section{Bacteriological Analyses}

Measurements of bacteria in water samples collected in 1996 and analyzed by the Boulder County Health Department indicated the presence or absence of coliform, fecal coliform, and noncoliform bacteria. Coliform bacteria, the common species being Escherichia coli (E. coli), occur in large numbers in the intestines of warmblooded animals, and their presence in water supplies is considered an indication of fecal pollution. Though coliform bacteria are not directly harmful to humans, the presence of coliform bacteria in water suggests the possibility of pathogenic bacteria also being present.

Of 30 wells sampled in Boulder County in the 1976 study, only one sample had detectable coliform bacteria (table 3). In the 1996 study, 8 of 29 wells had detectable coliform bacteria ( 1 of the 30 wells sampled had an invalid sample with no culture growth). Of these eight wells, five had fecal coliform identified. Again, as with some of the other constituents compared after a 20 -year time period, it is difficult to make a confident comparison regarding the presence or absence of bacteria in the water samples. The bacteriological analyses for the two study periods were performed by separate laboratories, and it is possible that the methods for collecting and culturing bacteriological samples have changed over the last 2 decades.

\section{Pesticides}

Pesticides were analyzed in ground-water samples collected only in 1996 . The presence of pesticides in these water samples is evidence of anthropogenic effects on ground-water quality. All pesticides (46 compounds) analyzed in each sample and the MRL for each compound are listed in table 4. Four of the 30 wells sampled had detectable pesticides. These four wells and the pesticide compounds detected are listed in table 5. Atrazine is a herbicide used to control broad-leaved weeds and grasses. Atrazine most commonly is applied to corn in agricultural settings but may have limited use by licensed applicators in urban settings to control weeds along roadways and around parking lots and other commercial or industrial facilities. Deethylatrazine is a breakdown product of atrazine. Prometon is a nonselective herbicide generally used as a soil sterilant. If properly applied, prometon is advertised to allow no vegetation growth in the application area for more than a year (Ciba-Geigy, 1991). Consequently, prometon is almost exclusively used in urban environments. Ciba-Geigy (1991) also indicates that prometon can be incorporated into asphalt pavement to increase the life expectancy of paved surfaces. All water samples with detectable pesticides were collected in the plains part of Boulder County. No pesticide compounds were detected in the wells sampled in the mountainous part of Boulder County.

\section{Volatile Organic Compounds}

As with the pesticides, volatile organic compounds (VOC's) were analyzed in water samples collected only in 1996, and the presence of these compounds is evidence of anthropogenic effects on water quality. The common name and MRL's for each VOC analyzed are listed in table 6. Of the 29 VOC's measured, 6 compounds were detected at least once, and 8 of 30 water samples had detectable concentrations of one or more of these compounds. These eight wells and the VOC's detected are listed in table 7. The drinking-water MCL's for applicable compounds also are listed.

The most frequently detected VOC in samples collected in 1996 was chloroform, which was detected in four wells. Chloroform in water can be the result of the use of chlorine as a drinking-water disinfectant. 
Tabie 3. Results of coliform bacteria analyses for wells sampled in 1976 and 1996 in Boulder County [mL, milliliter; <, less than; >, greater than; **, no analysis; est., estimated]

\begin{tabular}{|c|c|c|c|c|}
\hline \multirow[b]{2}{*}{ Well number } & \multicolumn{2}{|c|}{1976} & \multicolumn{2}{|c|}{1996} \\
\hline & $\begin{array}{l}\text { Total collform } \\
\text { (per } 100 \mathrm{~mL} \text { ) }\end{array}$ & $\begin{array}{l}\text { Fecal collform } \\
\text { (per } 100 \mathrm{~mL} \text { ) }\end{array}$ & $\begin{array}{c}\text { Total } \\
\text { collform }\end{array}$ & $\begin{array}{c}\text { Fecal } \\
\text { coliform }\end{array}$ \\
\hline $\mathrm{C} 01$ & $<1$ & $<1$ & Absent & Absent \\
\hline $\mathrm{C} 05$ & $<1$ & $<1$ & Present & Absent \\
\hline $\mathrm{C} 07$ & $<1$ & $<1$ & Absent & Absent \\
\hline $\mathrm{C} 09$ & $<1$ & $<1$ & ** & ** \\
\hline $\mathrm{Cl} 6$ & $<1$ & $<1$ & Absent & Absent \\
\hline $\mathrm{C} 24$ & $<1$ & $<1$ & Absent & Absent \\
\hline $\mathrm{C} 25$ & $<1$ & $<1$ & Absent & Absent \\
\hline $\mathrm{C} 27$ & $<1$ & $<1$ & Present & Absent \\
\hline C31 & $<1$ & $<1$ & Absent & Absent \\
\hline C33 & ** & ** & Present & Absent \\
\hline C34 & $<1$ & $<1$ & Absent & Absent \\
\hline C35 & $<1$ & $<1$ & Absent & Absent \\
\hline C41 & $<1$ & $<1$ & Present & Present \\
\hline C44 & $<1$ & $<1$ & Present & Present \\
\hline C46 & $<1$ & $<1$ & Absent & Absent \\
\hline C52 & $<1$ & $<1$ & Absent & Absent \\
\hline C53 & $>320$ & $>60$ & Absent & Absent \\
\hline C55 & $<1$ & $<1$ & Present & Present \\
\hline C58 & $<1$ & $<1$ & Absent & Absent \\
\hline C63 & $<1$ & $<1$ & Present & Present \\
\hline C66 & $<1$ & $<1$ & Absent & Absent \\
\hline C69 & $<1$ & $<1$ & Absent & Absent \\
\hline $\mathrm{C} 70$ & $<1$ & $<1$ & Absent & Absent \\
\hline $\mathrm{C} 73$ & $<1$ & $<1$ & Absent & Absent \\
\hline C75 & $<1$ & $<1$ & Absent & Absent \\
\hline C77 & $<1$ & $<1$ & Present & Present \\
\hline C79 & 1.0 (est.) & $<1$ & Absent & Absent \\
\hline C86 & $<1$ & $<1$ & Absent & Absent \\
\hline C89 & $<1$ & $<1$ & Absent & Absent \\
\hline C92 & $<1$ & $<1$ & Absent & Absent \\
\hline
\end{tabular}


Table 4. Pesticide compounds analyzed for wells sampled in 1996 in Boulder County

[n/a, not applicable; $\mu \mathrm{g} / \mathrm{L}$, micrograms per liter; $\mathrm{MRL}$, method reporting limit; $\mathrm{MCL}$, maximum contaminant level]

\begin{tabular}{|c|c|c|c|}
\hline Pestlclde common name & Pesticlde use & $\begin{array}{l}\text { MRL } \\
(\mu g / L)\end{array}$ & $\begin{array}{c}\text { MCL } \\
(\mu \mathrm{g} / \mathrm{L})\end{array}$ \\
\hline $2,4-D$ & Herbicide & 0.2 & $\mathrm{n} / \mathrm{a}$ \\
\hline Acetachlor & Herbicide & 0.1 & $\mathrm{n} / \mathrm{a}$ \\
\hline Alachlor & Herbicide & 0.1 & 2.0 \\
\hline Aldicarb & Insecticide & 1.0 & 7.0 \\
\hline Aldicarb sulfone & $\mathrm{n} / \mathrm{a}$ & 1.0 & 7.0 \\
\hline Aldicarb sulfoxide & $\mathrm{n} / \mathrm{a}$ & 1.0 & 7.0 \\
\hline Atrazine & Herbicide & 0.1 & 3.0 \\
\hline Deethylatrazine & $\mathbf{n} / \mathbf{a}$ & 0.2 & $\mathrm{n} / \mathrm{a}$ \\
\hline Deisopropylatrazine & $\mathrm{n} / \mathrm{a}$ & 0.2 & $\mathrm{n} / \mathrm{a}$ \\
\hline Benfluralin & Herbicide & 0.2 & $\mathrm{n} / \mathrm{a}$ \\
\hline Bromacil & Herbicide & 0.4 & $\mathrm{n} / \mathrm{a}$ \\
\hline Captan & Fungicide & 1.4 & $\mathrm{n} / \mathrm{a}$ \\
\hline Carbaryl & Insecticide & 1.0 & $\mathrm{n} / \mathrm{a}$ \\
\hline Carbofuran & Insecticide & 1.0 & 40.0 \\
\hline 3-Hydroxy-carbofuran & $\mathrm{n} / \mathrm{a}$ & 1.0 & $\mathrm{n} / \mathrm{a}$ \\
\hline Chlorothalonil & Fungicide & 0.1 & $\mathrm{n} / \mathrm{a}$ \\
\hline Chlorpyrifos & Insecticide & 0.1 & $\mathrm{n} / \mathrm{a}$ \\
\hline Cyanazine & Herbicide & 0.2 & $\mathrm{n} / \mathrm{a}$ \\
\hline DCPA & Herbicide & 0.1 & $\mathrm{n} / \mathrm{a}$ \\
\hline Diazinon & Insecticide & 0.2 & $n / a$ \\
\hline Dicamba & Herbicide & 0.1 & $\mathrm{n} / \mathrm{a}$ \\
\hline Dichlobenil & Herbicide & 0.1 & $\mathrm{n} / \mathrm{a}$ \\
\hline Dimethoate & Insecticide & 0.5 & $\mathrm{n} / \mathrm{a}$ \\
\hline $\mathrm{p}, \mathrm{p}-\mathrm{DDT}$ & Insecticide & 0.4 & $\mathbf{n} / \mathbf{a}$ \\
\hline Endrin & Insecticide & 0.3 & 2.0 \\
\hline Heptachlor & Insecticide & 0.6 & 0.4 \\
\hline Heptachlor epoxide & Insecticide & 0.8 & 0.2 \\
\hline Hexazinone & Herbicide & 0.1 & $\mathrm{n} / \mathrm{a}$ \\
\hline Lindane & Insecticide & 0.1 & 0.2 \\
\hline Malathion & Insecticide & 0.1 & $\mathrm{n} / \mathrm{a}$ \\
\hline MCPA & Herbicide & 2.0 & $\mathrm{n} / \mathrm{a}$ \\
\hline MCPP & Herbicide & 2.0 & $\mathrm{n} / \mathrm{a}$ \\
\hline Metalaxyl & Fungicide & 0.2 & $\mathrm{n} / \mathrm{a}$ \\
\hline Methiocarb & Insecticide & 1.0 & $\mathrm{n} / \mathrm{a}$ \\
\hline Methomyl & Insecticide & 1.0 & $\mathrm{n} / \mathrm{a}$ \\
\hline Methoxychlor & Insecticide & 0.9 & 40.0 \\
\hline Metolachlor & Herbicide & 0.1 & $\mathrm{n} / \mathrm{a}$ \\
\hline Metribuzin & Herbicide & 0.5 & $\mathrm{n} / \mathrm{a}$ \\
\hline 1-Naphthol & Insecticide & 1.0 & $\mathrm{n} / \mathrm{a}$ \\
\hline Oxamyl & Insecticide & 1.0 & 200.0 \\
\hline Pendimethalin & Herbicide & 1.2 & $n / a$ \\
\hline Picloram & Herbicide & 0.35 & 500.0 \\
\hline Prometon & Herbicide & 0.1 & $n / a$ \\
\hline Propoxur & Insecticide & 1.0 & $\mathrm{n} / \mathrm{a}$ \\
\hline Simazine & Herbicide & 0.2 & 4.0 \\
\hline Trifluralin & Herbicide & 0.3 & $\mathrm{n} / \mathrm{a}$ \\
\hline
\end{tabular}


Table 5. Concentrations and maximum contaminant levels for pesticide compounds detected in wells sampled in 1996 in Boulder County

[Concentrations in micrograms per liter; MCL, maximum contaminant level; n/a, not applicable]

\begin{tabular}{lccc}
\hline $\begin{array}{c}\text { Compound } \\
\text { name }\end{array}$ & $\begin{array}{c}\text { Well } \\
\text { number }\end{array}$ & Concentration & MCL \\
\hline Atrazine & $\mathrm{C} 25$ & 0.88 & 3 \\
Deethylatrazine* & $\mathrm{C} 25$ & 0.5 & $\mathrm{n} / \mathrm{a}$ \\
Prometon & $\mathrm{C} 27$ & 0.3 & (listed for regulation) \\
& $\mathrm{C} 73$ & 0.28 & \\
& $\mathrm{C} 92$ & 0.25 & \\
\hline
\end{tabular}

*Deethylatrazine is a breakdown product of the pesticide atrazine.

Table 6. Volatile organic compounds (VOC's) analyzed for wells sampled in 1996 in Boulder County

[MRL, method reporting limit; MCL, maximum contaminant level; $\mu \mathrm{g} / \mathrm{L}$, micrograms per liter; $n / a$, not applicable]

\begin{tabular}{|c|c|c|}
\hline Common name & $\begin{array}{c}\text { MRL } \\
(\mu \mathrm{g} / \mathrm{L})\end{array}$ & $\begin{array}{c}\text { MCL } \\
(\mu \mathrm{g} / \mathrm{L})\end{array}$ \\
\hline Benzene & 0.2 & 5.0 \\
\hline Bromoform & 0.2 & $80 .^{*}$ \\
\hline Carbontetrachloride & 0.2 & 5.0 \\
\hline Chlorobenzene & 0.2 & $\mathrm{n} / \mathbf{a}$ \\
\hline Chlorodibromomethane & 0.2 & $80 . *$ \\
\hline Chloroform & 0.2 & $80 .^{*}$ \\
\hline 1,2-Dichlorobenzene & 0.2 & 600. \\
\hline 1,3-Dichlorobenzene & 0.2 & $\mathrm{n} / \mathrm{a}$ \\
\hline 1,4-Dichlorobenzene & 0.2 & 75. \\
\hline Dichlorobromomethane & 0.2 & $80 .^{*}$ \\
\hline Dichlorodifluoromethane & 0.2 & $\mathrm{n} / \mathrm{a}$ \\
\hline 1,1-Dichloroethane & 0.2 & $\mathrm{n} / \mathrm{a}$ \\
\hline 1,2-Dichloroethane & 0.2 & 5. \\
\hline cis-1,2-Dichloroethene & 0.2 & 70. \\
\hline trans-1,2-Dichloroethene & 0.2 & 100. \\
\hline 1,1-Dichloroethene & 0.2 & 7. \\
\hline 1,1-Dichloropropane & 0.2 & $\mathrm{n} / \mathbf{a}$ \\
\hline Ethylbenzene & 0.2 & 700. \\
\hline Freon 113 & 0.2 & $\mathrm{n} / \mathrm{a}$ \\
\hline MethylenechIoride & 0.2 & $\mathrm{n} / \mathrm{a}$ \\
\hline Methyl-tert-butyl-ether & 0.2 & $\mathrm{n} / \mathrm{a}$ \\
\hline Styrene & 0.2 & 100. \\
\hline Tetrachloroethene & 0.2 & 5. \\
\hline Toluene & 0.2 & 1,000 . \\
\hline 1,1,1-Trichloroethane & 0.2 & 200. \\
\hline Trichloroethene & 0.2 & 5. \\
\hline Trichlorofluoromethane & 0.2 & $\mathrm{n} / \mathrm{a}$ \\
\hline Vinylchloride & 0.2 & 2. \\
\hline Xylene & 0.2 & 10,000 \\
\hline
\end{tabular}

MCL from U.S. Environmental Protection Agency (1996).

*1994 proposed rule for Disinfectants and Disinfection By-products: Total for all trihalomethanes combined cannot exceed the $80-\mu \mathrm{g} / \mathrm{L}$ level. 
Table 7. Concentrations and maximum contaminant levels of volatile organic compounds detected in wells sampled in 1996 in Boulder County

[ $\mu \mathrm{g} / \mathrm{L}$, micrograms per liter; $\mathrm{n} / \mathrm{a}$, not applicable; MCL, maximum contaminant level]

\begin{tabular}{|c|c|c|c|}
\hline Compound & $\begin{array}{c}\text { Well } \\
\text { number }\end{array}$ & $\begin{array}{c}\text { Concentration } \\
(\mu \mathrm{g} / \mathrm{L})\end{array}$ & $\begin{array}{l}\mathrm{MCL} \\
(\mu \mathrm{g} / \mathrm{L})\end{array}$ \\
\hline \multirow[t]{4}{*}{ Chloroform } & $\mathrm{Cl6}$ & 0.5 & \multirow{4}{*}{$\begin{array}{l}\text { Total trihalomethanes: } \\
80.0\end{array}$} \\
\hline & $\mathrm{C} 33$ & 0.05 & \\
\hline & $\mathrm{C} 75$ & 1.1 & \\
\hline & $\mathrm{C} 89$ & 0.6 & \\
\hline \multirow[t]{2}{*}{ 1,1,1-Trichloroethane } & C69 & 9.5 & \multirow[t]{2}{*}{200} \\
\hline & $\mathrm{C} 73$ & 0.3 & \\
\hline Benzene & $\mathrm{C} 53$ & 4.8 & 5.0 \\
\hline 1,1-Dichloroethane & $\mathrm{C} 73$ & 0.2 & $\mathrm{n} / \mathrm{a}$ \\
\hline 1,1-Dichloroethene & C69 & 3.8 & 7.0 \\
\hline Methyl-tert-butyl-ether & $\mathrm{C} 92$ & 0.9 & $\mathrm{n} / \mathrm{a}$ \\
\hline
\end{tabular}

Widespread use of chlorine for direct disinfection of wells or the application of chlorinated municipal water for lawn irrigation creates multiple pathways for chlorine to enter the ground-water system. The USEPA's 1994 proposed rule for disinfectants and disinfectant by-products in drinking water states that the total concentration for all trihalomethanes (THM's) combined cannot exceed the $80-\mu \mathrm{g} / \mathrm{L}$ level.

The VOC's 1,1,1-trichloroethane, 1,1-dichloroethane, and 1,1-dichloroethene are all organic solvents or the degradation products of organic solvents. Two of the 30 wells sampled contained these solvents or degradation products. The concentration of 1,1-dichloroethene in well $\mathrm{C} 69$ was more than one-half of the MCL.

The compound methyl-tert-butyl-ether (MTBE) is used as a gasoline additive in several cities along the Front Range urban corridor in Colorado. MTBE was detected in one well sampled. This compound is added to oxygenate motor fuels and to reduce the carbon monoxide emissions. It also is used in some premium grade gasolines as an octane enhancer. The use of this compound in the area began in the mid-to-late 1970's; however, its use as a fuel oxygenate has greatly decreased in recent years. Bruce and McMahon (1996) reported widespread occurrence of MTBE in ground water of the Denver, Colo., metropolitan area.

Benzene also was detected in one well in Boulder County. Though the concentration of benzene in this sample was close to the drinking-water MCL, it is not believed to be the result of anthropogenic contamination. The well where benzene was detected (C53) was a deep, flowing well originally drilled for oil and gas exploration. The discharge from the well had a strong hydrocarbon smell, and the water sample was dark in tint. It is believed that the water from this well comes from a deep source (greater than 2,000 ft) and that the water in this part of the aquifer was recharged many years ago. The benzene detected in well C53 is thought to be associated with naturally occurring hydrocarbons.

\section{Tritium}

Tritium is an isotope of hydrogen. Tritium atoms are unstable and undergo radioactive decay with a half-life of approximately 12.3 years. Consequently, the occurrence of tritium in ground water has been adapted as an age-dating tool to determine the approximate time that ground water was recharged to the aquifer and isolated from the atmospheric source of tritium. During the 1950's and early 1960's a substantial amount of anthropogenic tritium was released to the Earth's atmosphere during above-ground testing of nuclear bombs. This atmospheric "spike" of tritium left its signature on ground water recharged during and after this time. Tritium concentrations in precipitation have varied considerably from place to place during different years and seasons, making the use of tritium as a short-term dating tool problematic. Tritium can, however, be used as a semiquantitative dating tool in the following ways: (1) ground water with little or no tritium [less than $1.5 \mathrm{pCi} / \mathrm{L}$ or 0.5 tritium units (TU)] generally is considered to have been recharged to the aquifer prior to 1952 (pre-bomb water); (2) ground 
water with elevated tritium concentrations (greater than $30 \mathrm{pCi} / \mathrm{L}$ or $10 \mathrm{TU}$ ) is thought to have been recharged after 1952 (post-bomb water); and (3) ground water with tritium between these concentrations is considered to be a mixture of pre- and postbomb water. However, it is impossible to determine the percentage of water contributed from each period on the basis of tritium data alone (Mazor, 1991). The value of tritium age dating of ground water in Boulder County is to indicate the validity of nondetections of anthropogenic compounds. If a water sample does not contain anthropogenic constituents, it is important to document that these nondetections are not simply the result of sampling "old" water.

Twenty of 30 wells in the Boulder County study were sampled for tritium in 1996. The results are listed in Appendix $A$ at the back of this report. In general, all but 3 of the 20 wells sampled for tritium indicate recent (post-bomb) recharge dates for the water samples. Wells C44 and C70 have tritium concentrations that suggest recharge occurred prior to 1952 . Well C79 (tritium concentration, $5.4 \mathrm{pCi} / \mathrm{L}$ ) is slightly above the pre-bomb concentration; however, the sampling point for this water was immediately downgradient from a fairly large holding reservoir. Though water only remained in this holding reservoir for a matter of minutes due to large flow-through volume, it is reasonable to assume that some atmospheric exchange of tritium might take place during residence in this reservoir.

\section{BOULDER CREEK GAIN-AND-LOSS STUDY}

On October 24, 1996, streamflow measurements were made to determine the amount of water entering or leaving Boulder Creek through interactions with the adjacent ground-water system. The study method used a water mass balance where surface-water flow was measured at various points along Boulder Creek, and all outflows from and inflows to the stream were quantified. The measured discharge and the rates of inflows and outflows for each stream segment are listed in table 8 . The accuracy of a discharge measurement using standard USGS methods is estimated at plus or minus 5 percent. Based on these measurements, gain or loss of flow in the stream not accounted for in the mass balance is assumed to be the result of interaction with the ground-water system. The reach of Boulder Creek where the gain-and-loss study was done and the 11 sites where surface-water discharge measurements were made on the main stem of Boulder Creek are shown in figure 8 . Discharge measurements were taken in a timed downstream sequence. This allows for changes in discharge to be calculated relative to similar flow conditions as measured at the previous upstream site. Site 1 near the mouth of Boulder Canyon was the first site measured during the October 24, 1996, gain-and-loss study (fig. 8). The study ended at site 11 , just upstream from the effluent discharge from the 75th Street wastewater-treatment facility.

The result of the mass-balance calculations of surface-water discharge are presented graphically as a residual discharge in figure 9 . The residual discharge is calculated in feet cubed per second by using the measured streamflow entering the upstream end of a given stream segment, subtracting the volume of all outflows and adding the volume of all inflows within the stream segment, and comparing the resulting water volume to the amount of streamflow measured leaving the downstream end of the stream segment. A negative value for a stream segment indicates a loss of streamflow to the ground water. A positive value indicates a gain in streamflow from discharging ground water. Overall, after accounting for the major outflows by irrigation diversions, surface-water flow had a net gain in this reach of Boulder Creek. Most of the gain in flow from ground-water discharge occurred in the downstream segments of the stream reach.

Gain-and-loss studies are highly dependent on the existing hydrologic conditions. The results only represent the ground-water/surface-water relation for hydrologic conditions similar to those at the time of the study. This study was done in late summer when flow in the stream was small, irrigation and agricultural diversions were greatly reduced, and there had been little precipitation in the preceding week. Other gain-and-loss studies performed under different hydrologic conditions may well indicate different responses for each stream segment. Other similar studies under varied flow regimes would be required to document the complex interactions of ground water and surface water for this stream reach. 
Table 8. Data used to calculate a surface-water flow mass balance for gain-and-loss study performed on October 24, 1996, for Boulder Creek

[Discharge, outflow, and inflow, in cubic feet per second $\left(\mathrm{ft}^{3} / \mathrm{s}\right)$ ]

\begin{tabular}{|c|c|c|c|c|c|c|c|}
\hline Stream reach & $\begin{array}{c}\text { Site locatlon } \\
\text { (on Boulder Creek) }\end{array}$ & $\begin{array}{l}\text { Time of } \\
\text { measurement } \\
\text { (upstream- } \\
\text { downstream) }\end{array}$ & $\begin{array}{c}\text { Stream } \\
\text { dlscharge } \\
\text { at } \\
\text { upstream } \\
\text { site }\end{array}$ & $\begin{array}{c}\text { Cumula- } \\
\text { tive outflow } \\
\text { (subtract) }\end{array}$ & $\begin{array}{l}\text { Cumula- } \\
\text { tIve Inflow } \\
\text { (add) }\end{array}$ & $\begin{array}{c}\text { Stream } \\
\text { dlscharge at } \\
\text { downstream } \\
\text { slte }\end{array}$ & $\begin{array}{l}\text { Residual } \\
\text { dlscharge }\end{array}$ \\
\hline $\begin{array}{l}\text { From: Site } 1 \\
\text { To: Site } 2\end{array}$ & $\begin{array}{l}\text { Site 1, below Anderson Ditch } \\
\text { Site } 2 \text {, at } 6 \text { th Street }\end{array}$ & $0949-1042$ & 41.1 & 2.42 & none & 34.3 & -4.38 \\
\hline $\begin{array}{l}\text { From: Site } 2 \\
\text { To: Site } 3\end{array}$ & $\begin{array}{l}\text { Site 2, at 6th Street } \\
\text { Site 3, at 12th Street }\end{array}$ & $1042-1130$ & 34.3 & none & 0.01 & 37.3 & 2.99 \\
\hline $\begin{array}{l}\text { From: Site } 3 \\
\text { To: Site } 4\end{array}$ & $\begin{array}{l}\text { Site 3, at } 12 \text { th Street } \\
\text { Site } 4 \text {, at } 19 \text { th Street }\end{array}$ & $1130-1238$ & 37.3 & 0.63 & none & 36.2 & -0.47 \\
\hline $\begin{array}{l}\text { From: Site } 4 \\
\text { To: Site } 5\end{array}$ & $\begin{array}{l}\text { Site } 4 \text {, at } 19 \text { th Street } \\
\text { Site } 5 \text {, at } 28 \text { th Street }\end{array}$ & $1238-1307$ & 36.2 & none & 0.17 & 33.6 & -2.77 \\
\hline $\begin{array}{l}\text { From: Site } 5 \\
\text { To: Site } 6\end{array}$ & $\begin{array}{l}\text { Site 5, at } 28 \text { th Street } \\
\text { Site 6, above Arapahoe Road }\end{array}$ & $1307-1415$ & 33.6 & 4.74 & 0.10 & 30.8 & 1.84 \\
\hline $\begin{array}{l}\text { From: Site } 8 \\
\text { To: Site } 9\end{array}$ & $\begin{array}{l}\text { Site 8, at 55th Street } \\
\text { Site 9, above South Boulder Creek }\end{array}$ & $1640-1750$ & 32.3 & none & none & 32.8 & 0.5 \\
\hline $\begin{array}{l}\text { From: Site } 9 \\
\text { To: Site } 10\end{array}$ & $\begin{array}{l}\text { Site } 9 \text {, above South Boulder Creek } \\
\text { Site } 10 \text {, near } 65 \text { th Street }\end{array}$ & $1750-1730$ & 32.8 & 7.14 & 2.81 & 33.4 & 4.93 \\
\hline $\begin{array}{l}\text { From: Site } 10 \\
\text { To: Site } 11\end{array}$ & $\begin{array}{l}\text { Site } 10 \text {, near } 65 \text { th Street } \\
\text { Site } 11 \text {, above } 75 \text { th Street }\end{array}$ & $1730-1850$ & 33.4 & none & 1.30 & 40.2 & 5.5 \\
\hline
\end{tabular}









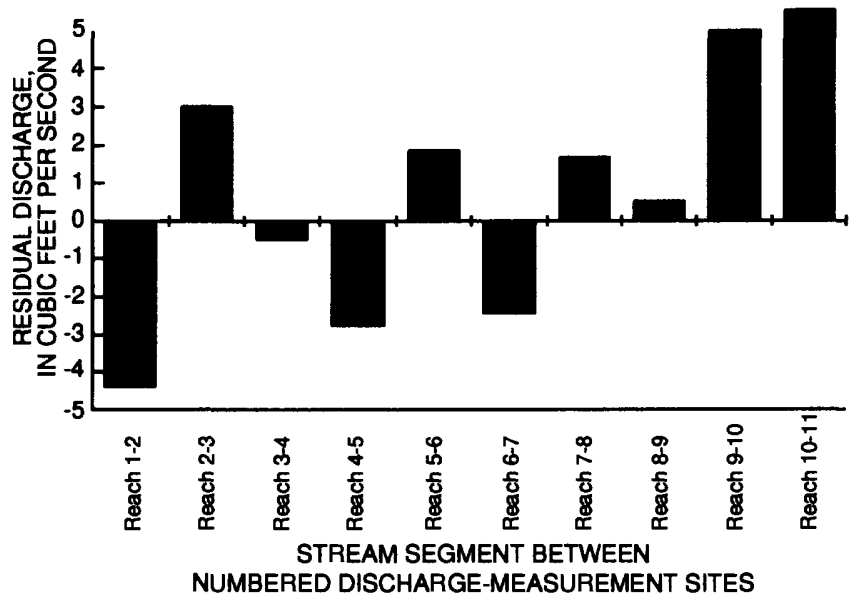

Figure 9. Residual discharge from a water mass balance on Boulder Creek.

\section{SUMMARY}

From 1975 to 1977 (referred to herein as 1976), the U.S. Geological Survey, in cooperation with the Boulder County Health Department and the Colorado Geological Survey, sampled numerous surface-water and ground-water sites throughout Boulder County. In 1996, the U.S. Geological Survey, in cooperation with the Boulder County Health Department and the City of Boulder, resampled 30 of the same wells from the 1976 study in order to compare water-quality data from the two study periods.

Though the summed concentrations of dissolved solids were nearly identical between the two study periods, the median concentrations of sulfate and chloride exhibited large differences. The median concentration of sulfate was 47 percent less in 1996 than in 1976. The median concentration of chloride was 50 percent greater in 1996 . Nitrite plus nitrate concentrations for the two study periods showed a statistically significant decline in concentration over 20 years; however, when comparing mountain wells only, there was an apparent increase in nitrite plus nitrate concentrations; when comparing plains wells only, a significant decrease was observed.

Comparison of trace-element concentrations between the two study periods was problematic. Differences in the elements reported, analytical techniques, and method reporting limits reduced the number of valid comparisons. Sampling technique also may have affected the trace-element results, as represented by large decreases in median concentra- tions of plumbing-related metals from 1976 to 1996. Uranium concentrations in 6 of 30 wells exceeded the proposed $20-\mu \mathrm{g} / \mathrm{L}$ MCL.

Eight of 29 wells had detectable coliform bacteria in samples collected in 1996, an increase from 1 of 30 in 1976. Of these eight wells with coliform bacteria in 1996, five wells had fecal coliform bacteria identified.

Forty-six pesticides and 29 volatile organic compounds were analyzed in samples collected in 1996. These compounds were not analyzed in 1976. Four pesticide compounds (4 of 30 wells) and six volatile organic compounds (8 of 30 wells) were detected in sampled wells. All wells with detections of these anthropogenic compounds were in the plains part of the study area. The compounds detected generally were associated with urban land-use activities.

A surface-water gain-and-loss study was performed on October 24, 1996, to quantify the volume of water exchange between the surface-water and adjacent ground-water systems along Boulder Creek through the urban reach of the stream. Though gains and losses generally were small, residual discharge has been calculated for each stream segment. Overall, the stream reach had a net gain in surface-water flow, with the majority of ground-water discharge to the stream occurring in downstream segments. Other gain-and-loss studies are needed to improve understanding of the ground-water/surfacewater interactions in this stream reach.

\section{REFERENCES CITED}

Bruce, B.W., and McMahon, P.B., 1996, Shallow groundwater quality beneath a major urban center-Denver, Colorado, USA: Journal of Hydrology, no. 186, p. 129-151.

Ciba-Geigy, 1991, Label for the herbicide Pramitol 25E (active ingredient: prometon), Product I.D. 06550, Label No. CGA 8L5X, EPA Reg. No. 100-443: in Crop Protection Chemicals Reference, 1993, Chemical and Pharmaceutical Publishing Corp., Paris, France, p. 397.

Hall, D.C., Boyd, E.L., and Cain, D.L., 1979, Hydrologic data for wells, springs, and streams in Boulder County, Colorado: U.S. Geological Survey Open-File Report 79-979, 106 p., 1 plate. 
Helsel, D.R., and Hirsch, R.M., 1995, Studies in environmental science 49-Statistical methods in water resources: Amsterdam, The Netherlands, Elsevier Science Publishers, $529 \mathrm{p}$.

Hem, J.D., 1989, Study and interpretation of the chemical characteristics of natural water: U.S. Geological Survey Water-Supply Paper 2254, 263 p.

Mazor, Emanuel, 1991, Applied chemical and isotopic groundwater hydrology: New York, N.Y., Halsted Press, 274 p.

Qi, S.L., and Dennehy, K.F., 1997, World Wide Web home page for the South Platte NAWQA: U.S. Geological Survey Fact Sheet FS-242-96.
Skougstad, M.W., Fishman, M.J., Friedman, L.C., Erdmann, D.E., and Duncan, S.S., 1979, Methods for determination of inorganic substances in water and fluvial sediments: U.S. Geological Survey Techniques of Water-Resources Investigations, book 5, chap. A1, $2 \mathrm{~d}$ edition, $160 \mathrm{p}$.

U.S. Environmental Protection Agency, 1994, National primary drinking water standards; February 1994: U.S. Environmental Protection Agency, Office of Water, Washington, D.C., EPA 810-F-94-001A, 5 p. 1996, Drinking water regulations and health advisories; October 1996: U.S. Environmental Protection Agency, Office of Water, EPA 822-B-96-002, $11 \mathrm{p}$. 


\section{APPENDIX A: Water-Quality Data}

Appendix A includes paired water-quality data for all inorganic constituents measured in Boulder County ground-water samples collected in 1975-77 (Hall and others, 1979) and in samples collected in 1996 specifically for this study. The analytical results were retrieved directly form the U.S. Geological Survey's National Water Information System (NWIS) data base. The data tables have been reformatted in a manner that minimizes the number of pages generated.

The following abbreviations are applicable to the appendix tables:

US/CM, $\mathrm{PH}$,

DEG C,

$M G / L$,

UG/L

$\mathrm{PCI} / \mathrm{L}$,

WH FET,

NONCARB

WH WAT TOT FLD, noncarbonate whole water total - field

AC-FT

U-NAT

$\mathrm{SR} / \mathrm{Y}-90$,

CS-137, microsiemens per centimeter at 25 degrees Celsius

$\mathrm{pH}$

degrees Celsius

milligrams per liter

micrograms per liter

picocuries per liter

whole field endpoint titration

acre-feet

uranium natural

strontium/yttrium-90

cesium-137 





WATER-QUALITY DATA

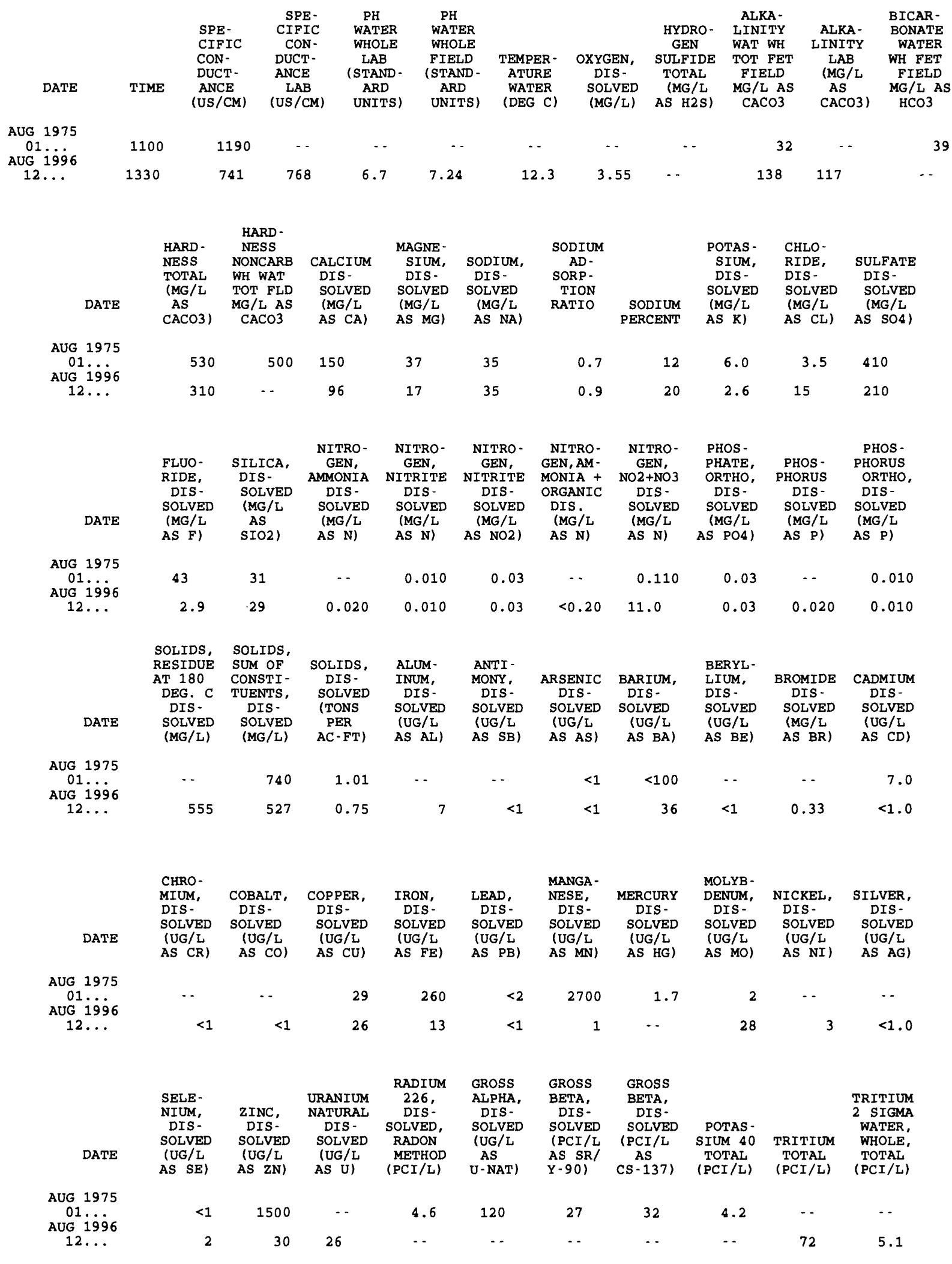


WATER-QUALITY DATA

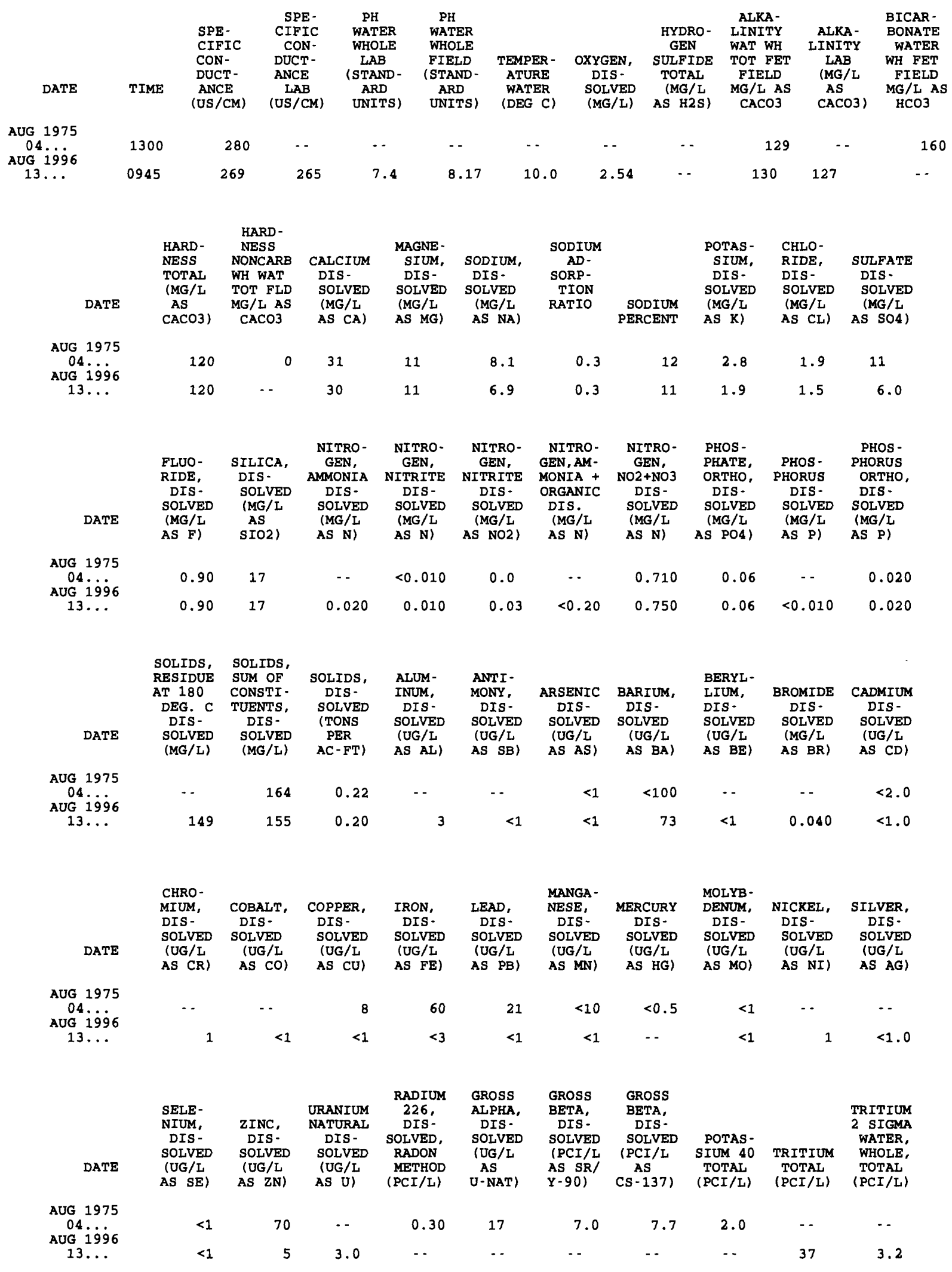


WATER-QUALITY DATA

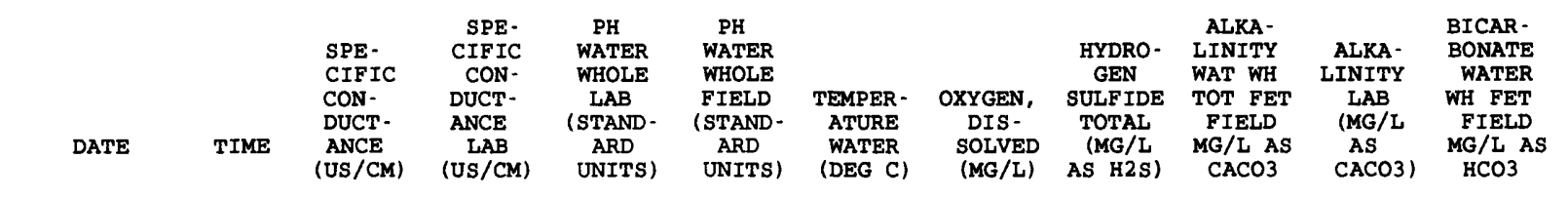

\begin{tabular}{|c|c|c|c|c|c|c|c|c|c|c|c|}
\hline $\begin{array}{l}\text { AUG } 1975 \\
08396 \\
\text { AUG } 1996\end{array}$ & 1300 & 230 & $\cdots$ & $\cdots$ & $\cdots$ & 21.5 & $\cdots$ & $\cdots$ & 92 & $\cdots$ & 110 \\
\hline $13 \ldots$ & 1230 & 276 & 250 & 7.1 & 8.38 & 10.4 & 3.55 & $\cdots$ & 84 & 102 & $\cdots$ \\
\hline
\end{tabular}

$\begin{array}{lll} & \text { HARD - } & \\ \text { HARD - } & \text { NESS } & \\ \text { NESS } & \text { NONCARB } & \text { CALCIUM } \\ \text { TOTAL } & \text { WH WAT } & \text { DIS- } \\ \text { (MG/L } & \text { TOT FLD } & \text { SOLVED } \\ \text { AS } & \text { MG/L AS } & \text { (MG/L } \\ \text { CACO3) } & \text { CACO3 } & \text { AS CA) }\end{array}$

$\begin{array}{ccc}\text { MAGNE- } & \text { SODIUM } \\ \text { SIUM, } & \text { SODIUM, } & \text { AD- } \\ \text { DIS- } & \text { DIS- } & \text { SORP- } \\ \text { SOLVED } & \text { SOLVED } & \text { TION } \\ \text { (MG/L } & \text { (MG/L } & \text { RATIO }\end{array}$

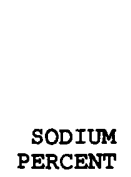

AUG 1975

AUG 1986

$13 \ldots$

AUG 1975

08

AUG 1996

$13 \ldots$

$\begin{array}{rrr}98 & 6 & 29 \\ 110 & - & \end{array}$

$$
\begin{array}{ll}
6.1 & 3.9 \\
5.6 & 4.9
\end{array}
$$

0.2

0.2

8

2.2
1.9

$\begin{array}{ll}1.1 & 19 \\ 1.0 & 23\end{array}$

POTAS - CHLO -

SIUM, RIDE, SULFATE

DIS - DIS- DIS-

SOLVED SOLVED SOLVED

(MG/L (MG/L (MG/L

\begin{tabular}{|c|c|c|c|c|c|c|c|c|c|}
\hline $\begin{array}{l}\text { LUO- } \\
\text { IDE, } \\
\text { DIS- } \\
\text { OLVED } \\
\text { MG/L } \\
\text { S F) }\end{array}$ & $\begin{array}{l}\text { SILICA, } \\
\text { DIS- } \\
\text { SOLVED } \\
\text { (MG/L } \\
\text { AS } \\
\text { SIO2) }\end{array}$ & $\begin{array}{c}\text { NITRO- } \\
\text { GEN, } \\
\text { AMMONIA } \\
\text { DIS- } \\
\text { SOLVED } \\
\text { (MG/L } \\
\text { AS N) }\end{array}$ & $\begin{array}{c}\text { NITRO- } \\
\text { GEN, } \\
\text { NITRITE } \\
\text { DIS- } \\
\text { SOLVED } \\
\text { (MG/L } \\
\text { AS N) }\end{array}$ & $\begin{array}{c}\text { NITRO- } \\
\text { GEN, } \\
\text { NITRITE } \\
\text { DIS- } \\
\text { SOLVED } \\
\text { (MG/L } \\
\text { AS NO2) }\end{array}$ & $\begin{array}{l}\text { NITRO- } \\
\text { GEN, AM- } \\
\text { MONIA + } \\
\text { ORGANIC } \\
\text { DIS. } \\
\text { (MG/L } \\
\text { AS N) }\end{array}$ & $\begin{array}{c}\text { NITRO- } \\
\text { GEN, } \\
\text { NO2+NO3 } \\
\text { DIS- } \\
\text { SOLVED } \\
\text { (MG/L } \\
\text { AS N) }\end{array}$ & $\begin{array}{c}\text { PHOS - } \\
\text { PHATE, } \\
\text { ORTHO, } \\
\text { DIS- } \\
\text { SOLVED } \\
\text { (MG/L } \\
\text { AS PO4) }\end{array}$ & $\begin{array}{l}\text { PHOS - } \\
\text { PHORUS } \\
\text { DIS - } \\
\text { SOLVED } \\
\text { (MG/L } \\
\text { AS P) }\end{array}$ & $\begin{array}{l}\text { PHOS - } \\
\text { PHORUS } \\
\text { ORTHO } \\
\text { DIS - } \\
\text { SOLVED } \\
\text { (MG/L } \\
\text { AS P) }\end{array}$ \\
\hline
\end{tabular}

PERCENT AS K) AS CL) AS SO4)
$0.30 \quad 12$
$+<0.010$
$0.0 \quad \ldots$
0.330
0.06
$-\cdot$
0.020
$0.30 \quad 12$
0.020
0.010
$0.03<0.20 \quad 0.100$
$0.03<0.010$
0.010

SOLIDS, SOLIDS,

RESIDUE' SUM OF

AT 180 CONSTI. DEG. C TUENTS, $\begin{array}{cc}\text { DIS- } & \text { DIS - } \\ \text { SOLVED } & \text { SOLVED } \\ (\mathrm{MG} / \mathrm{L}) & (\mathrm{MG} / \mathrm{L})\end{array}$

SOLIDS,

SOLVED

(TONS

PER
AC-FT)

-. 132

$$
0.18
$$

$150 \quad 147$

0.20

ALUM -

INUM

SOLVED

(UG/L

AS AL)
ANTI -

MONY, ARSENIC BARIUM,

MONY,

SOLVED SOLVED SOLVED

(UG/L (UG/L

AS AS) AS BA
BERYL -

LIUM, BROMIDE CADMIUM

LIUM:

DIS DIS -

(UG/L SOLVED

$\begin{array}{lll}(\mathrm{UG} / L & (\mathrm{MG} / \mathrm{L} & (\mathrm{UG} / \mathrm{L} \\ \text { AS BE) } & \text { AS BR) AS CD) }\end{array}$

\section{$08 \ldots$}

$13 \ldots$

AUG 1975

08 .

$13 \ldots$.

AUG 1975

08.196

$13 \ldots$
CHRO-

MIUM, COBALT, COPPER, DIS SOLVED (UG/L (UG/L (UG/L

AS CU)

AS $\mathrm{CO}$ )

7

$<1$
$<1<100$
$<1$

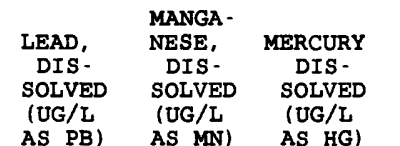

AS PB) AS MN) AS HG)

$\begin{array}{ccc}\ldots & \ldots & \text { ND } \\ <1 & 0.020 & <1.0\end{array}$

MOLYB -

DENUM, NICKEL, SILVER, DIS - DIS - DIS SOLVED SOLVED SOLVED

\begin{tabular}{|c|c|c|c|c|c|c|c|c|c|}
\hline$\cdots$ & - & 2 & 20 & 2 & $<10$ & $<0.5$ & $<1$ & -- & $\cdots$ \\
\hline 1 & $<1$ & 160 & 16 & 2 & 14 & - & $<1$ & 3 & $<1.0$ \\
\hline $\begin{array}{l}\text { SELE- } \\
\text { NIUM, } \\
\text { DIS- } \\
\text { SOLVED } \\
\text { (UG/L } \\
\text { AS SE) }\end{array}$ & $\begin{array}{c}\text { ZINC, } \\
\text { DIS- } \\
\text { SOLVED } \\
\text { (UG/L } \\
\text { AS ZN) }\end{array}$ & $\begin{array}{c}\text { URANIUM } \\
\text { NATURAL } \\
\text { DIS- } \\
\text { SOLVED } \\
\text { (UG/L } \\
\text { AS U) }\end{array}$ & $\begin{array}{c}\text { RADIUM } \\
226, \\
\text { DIS- } \\
\text { SOLVED, } \\
\text { RADON } \\
\text { METHOD } \\
\text { (PCI/L) }\end{array}$ & $\begin{array}{l}\text { GROSS } \\
\text { ALPHA, } \\
\text { DIS - } \\
\text { SOLVED } \\
\text { (UG/L } \\
\text { AS } \\
\text { U-NAT) }\end{array}$ & $\begin{array}{l}\text { GROSS } \\
\text { BETA, } \\
\text { DIS- } \\
\text { SOLVED } \\
(\text { PCI/L } \\
\text { AS SR/ } \\
\text { Y-90) }\end{array}$ & $\begin{array}{c}\text { GROSS } \\
\text { BETA, } \\
\text { DIS- } \\
\text { SOLVED } \\
\text { (PCI/L } \\
\text { AS } \\
\text { CS-137) }\end{array}$ & $\begin{array}{l}\text { POTAS - } \\
\text { SIUM } 40 \\
\text { TOTAL } \\
\text { (PCI/L) }\end{array}$ & $\begin{array}{l}\text { TRITIUM } \\
\text { TOTAL } \\
\text { (PCI/L) }\end{array}$ & $\begin{array}{c}\text { TRITIUM } \\
2 \text { SIGMA } \\
\text { WATER, } \\
\text { WHOLE, } \\
\text { TOTAL } \\
\text { (PCI/L) }\end{array}$ \\
\hline
\end{tabular}
(UG/L (UG/L (UG/L

AS MO) AS NI) AS AG) 
WATER-OUALITY DATA

\begin{tabular}{|c|c|c|c|c|c|c|c|c|c|c|c|}
\hline DATE & TIME & $\begin{array}{l}\text { SPE- } \\
\text { CIFIC } \\
\text { CON- } \\
\text { DUCT- } \\
\text { ANCE } \\
\text { (US/CM) }\end{array}$ & $\begin{array}{c}\text { SPE- } \\
\text { CIFIC } \\
\text { CON- } \\
\text { DUCT- } \\
\text { ANCE } \\
\text { LAB } \\
\text { (US/CM) }\end{array}$ & $\begin{array}{c}\text { PH } \\
\text { WATER } \\
\text { WHOLE } \\
\text { LAB } \\
\text { (STAND- } \\
\text { ARD } \\
\text { UNITS) }\end{array}$ & $\begin{array}{c}\text { PH } \\
\text { WATER } \\
\text { WHOLE } \\
\text { FIELD } \\
\text { (STAND- } \\
\text { ARD } \\
\text { UNITS) }\end{array}$ & $\begin{array}{c}\text { TEMPER - } \\
\text { ATURE } \\
\text { WATER } \\
\text { (DEG C) }\end{array}$ & $\begin{array}{c}\text { OXYGEN, } \\
\text { DIS - } \\
\text { SOLVED } \\
\text { (MG/L) }\end{array}$ & $\begin{array}{l}\text { HYDRO- } \\
\text { GEN } \\
\text { SULFIDE } \\
\text { TOTAL } \\
\text { (MG/L } \\
\text { AS H2S) }\end{array}$ & $\begin{array}{l}\text { ALKA- } \\
\text { LINITY } \\
\text { WAT WH } \\
\text { TOT FET } \\
\text { FIELD } \\
\text { MG/L AS } \\
\text { CACO3 }\end{array}$ & $\begin{array}{c}\text { ALKA- } \\
\text { LINITY } \\
\text { LAB } \\
\text { (MG/L } \\
\text { AS } \\
\text { CACO3) }\end{array}$ & $\begin{array}{c}\text { BICAR- } \\
\text { BONATE } \\
\text { WATER } \\
\text { WH FET } \\
\text { FIELD } \\
\text { MG/L AS } \\
\text { HCO3 }\end{array}$ \\
\hline $\begin{array}{l}\text { UL } 1976 \\
29 \\
\text { UG } 19966\end{array}$ & 0830 & 600 & - & $\cdots$ & - & - & $\cdots$ & - & -- & $-\cdot$ & 340 \\
\hline $14 \ldots$ & 1105 & 1001 & 965 & 7.1 & 7.83 & 13.4 & 3.41 & -. & 412 & 416 & - \\
\hline
\end{tabular}

\begin{tabular}{|c|c|c|c|c|c|c|c|c|c|}
\hline $\begin{array}{l}\text { HARD - } \\
\text { NESS } \\
\text { TOTAL } \\
\text { (MG/L } \\
\text { AS }\end{array}$ & $\begin{array}{l}\text { HARD - } \\
\text { NESS } \\
\text { NONCARB } \\
\text { WH WAT } \\
\text { TOT FLD } \\
\text { MG/L AS } \\
\text { CACO3 }\end{array}$ & $\begin{array}{l}\text { CALCIUM } \\
\text { DIS - } \\
\text { SOLVED } \\
\text { (MG/L } \\
\text { AS CA) }\end{array}$ & $\begin{array}{l}\text { MAGNE - } \\
\text { SIUM, } \\
\text { DIS - } \\
\text { SOLVED } \\
\text { (MG/L } \\
\text { AS MG) }\end{array}$ & $\begin{array}{l}\text { SODIUM, } \\
\text { DIS- } \\
\text { SOLVED } \\
\text { (MG/L } \\
\text { AS NA) }\end{array}$ & $\begin{array}{c}\text { SODIUM } \\
\text { AD - } \\
\text { SORP- } \\
\text { TION } \\
\text { RATIO }\end{array}$ & so & $\begin{array}{l}\text { POTAS - } \\
\text { SIUM, } \\
\text { DIS - } \\
\text { SOLVED } \\
\text { (MG/L } \\
\text { AS K) }\end{array}$ & $\begin{array}{l}\text { CHLO - } \\
\text { RIDE, } \\
\text { DIS - } \\
\text { SOLVED } \\
\text { (MG/L } \\
\text { AS CL) }\end{array}$ & $\begin{array}{l}\text { SULFATE } \\
\text { DIS- } \\
\text { SOLVED } \\
\text { (MG/L } \\
\text { AS SO4) }\end{array}$ \\
\hline
\end{tabular}

JUL 1976
29.7

AUG $199 \dot{9} 6$

$14 \ldots$

JUL 1976

$29 \ldots$

AUG $19 \dot{9} 6$

$14 \ldots$

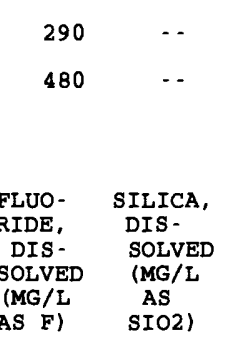

\begin{abstract}
86
\end{abstract}
140

$\begin{array}{ll}18 & 21 \\ 31 & 30\end{array}$

21

30
$0.5 \quad 14$
$0.6 \quad 12$

\begin{abstract}
1.5
\end{abstract}
$1.0 \quad 34$

21

42
PHOS - PHOS -

PHATE, PHOS- PHORUS

ORTHO, PHORUS ORTHO,

ORTHO, PHORUS - DIS - DIS -

SOLVED SOLVED SOLVED

(MG/L (MG/L (MG/L

AS PO4) AS P) AS P)
$0.40 \quad 14$
- $\quad 0.010$
0.03
-
3.50
0.0
- $\quad<0.010$
$0.30 \quad 16$
0.020
0.010
$0.03<0.20$
8.90
$0.03<0.010$
0.010

$\begin{array}{ccc} & \text { SOLIDS, } & \text { SOLIDS, } \\ & \text { RESIDUE } & \text { SUM OF } \\ & \text { AT } 180 & \text { CONSTI- } \\ & \text { DEG. C } & \text { TUENTS, } \\ \text { DATE } & \text { DIS- } & \text { DIS- } \\ & \text { SOLVED } & \text { SOLVED } \\ & \text { (MG/L) } & \text { (MG/L) }\end{array}$

SOLIDS, DIS SOLVED (TONS PER
AC-FT)
ALUM INUM, DIS SOLVED (UG/L AS AL)
ANTI MONY, ARSENIC BARIUM,
DISSOLVED (UG/L AS SB)

$\begin{array}{lc}\text { ARSENIC } & \text { BARIUM, } \\ \text { DIS- } & \text { DIS- } \\ \text { SOLVED } & \text { SOLVED } \\ \text { (UG } / L & \text { (UG/L }\end{array}$

$\begin{array}{cc}(\mathrm{UG} / L & (\mathrm{UG} / \mathrm{L} \\ \text { AS AS) } & \text { AS BA) }\end{array}$
BERYL $\begin{array}{lcc}\text { BERYL- } & \\ \text { LIUM, } & \text { BROMIDE } & \text { CADMIUM } \\ \text { DIS- } & \text { DIS- } & \text { DIS- }\end{array}$ SOLVED SOLVED SOLVED (UG/L (MG/L (UG/L AS BE) AS BR) AS CD)
JUL 1976
29
AUG 1996

14 ...

JUL 1976

29

AUG 1996

14 ...

JUL 1976

$29 \ldots$

AUG 1996

$14 \ldots$

$\begin{array}{ll}- & 356 \\ 586 & 584\end{array}$

0.48

0.80
$-$
$1<100$
$<1$
340

CHRO -

MIUM, COBALT,

$\begin{array}{lcccc}\text { COBALT, } & \text { COPPER, } & \text { IRON, } & \text { LEAD, } \\ \text { DIS- } & \text { DIS- } & \text { DIS- } & \text { DIS- } & \text { DIS- } \\ \text { SOLVED } & \text { SOLVED } & \text { SOLVED } & \text { SOLVED } & \text { SOLVED } \\ \text { (UG/L } & \text { (UG/L } & \text { (UG/L } & \text { (UG/L } & \text { (UG/L }\end{array}$

$\begin{array}{ccccc}(\mathrm{UG} / L & (\mathrm{UG} / L & (\mathrm{UG} / L & \text { (UG/L } & \text { (UG/L } \\ \text { AS CR) } & \text { AS CO) } & \text { AS CU) } & \text { AS FE) } & \text { AS PB) }\end{array}$
MANGA -

NESE, MERCURY

DIS - DIS -

SOLVED SOLVED

(UG/L (UG/L

$\begin{array}{ll}\text { AS MN) } & \text { AS HG) }\end{array}$ $\begin{array}{lll}- & - & <2.0 \\ <1 & 0.25 & <1.0\end{array}$

40 
WATER-QUALITY DATA

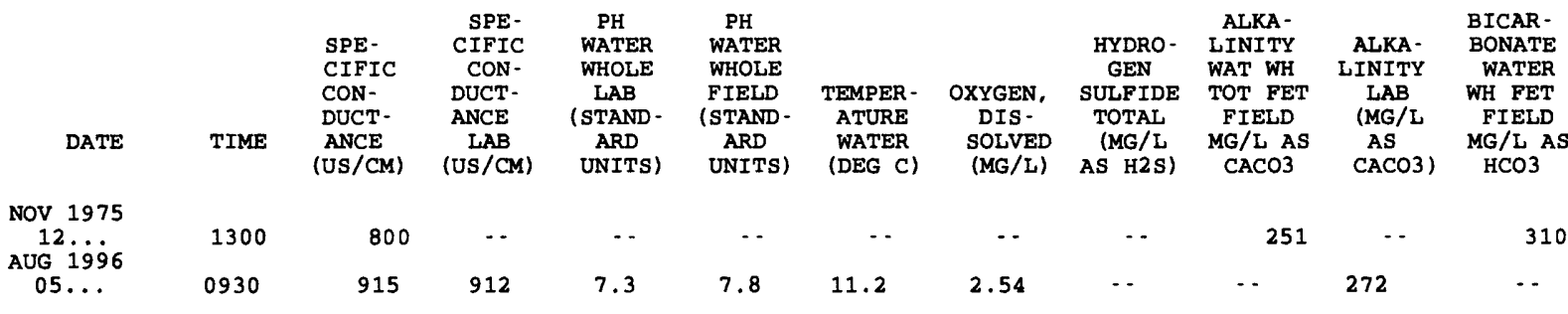

\begin{tabular}{|c|c|c|c|c|c|c|c|c|c|c|}
\hline DATE & $\begin{array}{l}\text { HARD - } \\
\text { NESS } \\
\text { TOTAL } \\
\text { (MG/L } \\
\text { AS } \\
\text { CACO3) }\end{array}$ & $\begin{array}{l}\text { HARD- } \\
\text { NESS } \\
\text { NONCARB } \\
\text { WH WAT } \\
\text { TOT FLD } \\
\text { MG/L AS } \\
\text { CACO3 }\end{array}$ & $\begin{array}{l}\text { CALCIUM } \\
\text { DIS - } \\
\text { SOLVED } \\
\text { (MG/L } \\
\text { AS CA) }\end{array}$ & $\begin{array}{l}\text { MAGNE- } \\
\text { SIUM, } \\
\text { DIS - } \\
\text { SOLVED } \\
\text { (MG/L } \\
\text { AS MG) }\end{array}$ & $\begin{array}{c}\text { SODIUM, } \\
\text { DIS - } \\
\text { SOLVED } \\
\text { (MG/L } \\
\text { AS NA) }\end{array}$ & $\begin{array}{c}\text { SODIUM } \\
\text { AD- } \\
\text { SORP- } \\
\text { TION } \\
\text { RATIO }\end{array}$ & $\begin{array}{r}\text { SODIUM } \\
\text { PERCENT }\end{array}$ & $\begin{array}{l}\text { POTAS - } \\
\text { SIUM, } \\
\text { DIS - } \\
\text { SOLVED } \\
\text { (MG/I } \\
\text { AS K) }\end{array}$ & $\begin{array}{l}\text { CHLO- } \\
\text { RIDE, } \\
\text { DIS- } \\
\text { SOLVED } \\
\text { (MG/L } \\
\text { AS CL) }\end{array}$ & $\begin{array}{c}\text { SULFATE } \\
\text { DIS- } \\
\text { SOLVED } \\
\text { (MG/L } \\
\text { AS SO4) }\end{array}$ \\
\hline $\begin{array}{c}\text { NOV } 1975 \\
12 \text {. } \\
\text { AUG } 1996 \\
05 \ldots\end{array}$ & 240 & $\cdots$ & 69 & 16 & 100 & 3 & 47 & 4.4 & 15 & 170 \\
\hline DATE & $\begin{array}{l}\text { FLUO- } \\
\text { RIDE, } \\
\text { DIS- } \\
\text { SOLVED } \\
\text { (MG/L } \\
\text { AS F) }\end{array}$ & $\begin{array}{c}\text { SILICA, } \\
\text { DIS- } \\
\text { SOLVED } \\
\text { (MG/L } \\
\text { AS } \\
\text { SIO2) }\end{array}$ & $\begin{array}{c}\text { NITRO- } \\
\text { GEN, } \\
\text { AMMONIA } \\
\text { DIS- } \\
\text { SOLVED } \\
\text { (MG/L } \\
\text { AS N) }\end{array}$ & $\begin{array}{c}\text { NITRO- } \\
\text { GEN, } \\
\text { NITRITE } \\
\text { DIS- } \\
\text { SOLVED } \\
\text { (MG/L } \\
\text { AS N) }\end{array}$ & $\begin{array}{c}\text { NITRO- } \\
\text { GEN, } \\
\text { NITRITE } \\
\text { DIS- } \\
\text { SOLVED } \\
\text { (MG/L } \\
\text { AS NO2) }\end{array}$ & $\begin{array}{l}\text { NITRO- } \\
\text { GEN, AM- } \\
\text { MONIA + } \\
\text { ORGANIC } \\
\text { DIS. } \\
\text { (MG/L } \\
\text { AS N) }\end{array}$ & $\begin{array}{c}\text { NITRO- } \\
\text { GEN, } \\
\text { NO2+NO3 } \\
\text { DIS - } \\
\text { SOLVED } \\
\text { (MG/L } \\
\text { AS N) }\end{array}$ & $\begin{array}{c}\text { PHOS- } \\
\text { PHATE, } \\
\text { ORTHO, } \\
\text { DIS - } \\
\text { SOLVED } \\
\text { (MG/L } \\
\text { AS PO4) }\end{array}$ & $\begin{array}{c}\text { PHOS - } \\
\text { PHORUS } \\
\text { DIS - } \\
\text { SOLVED } \\
\text { (MG/L } \\
\text { AS P) }\end{array}$ & $\begin{array}{l}\text { PHOS - } \\
\text { PHORUS } \\
\text { ORTHO, } \\
\text { DIS- } \\
\text { SOLVED } \\
\text { (MG/L } \\
\text { AS P) }\end{array}$ \\
\hline $\begin{array}{c}\text { NOV } 1975 \\
12 \text { AUG } 1996\end{array}$ & 1.5 & 21 & $\cdots$ & $<0.010$ & 0.0 & $\cdots$ & 0.470 & 0.03 & $\cdots$ & 0.010 \\
\hline DATE & $\begin{array}{c}\text { SOLIDS, } \\
\text { RESIDUE } \\
\text { AT } 180 \\
\text { DEG. C } \\
\text { DIS - } \\
\text { SOLVED } \\
\text { (MG/L) }\end{array}$ & $\begin{array}{c}\text { SOLIDS, } \\
\text { SUM OF } \\
\text { CONSTI - } \\
\text { TUENTS, } \\
\text { DIS - } \\
\text { SOLVED } \\
\text { (MG/L) }\end{array}$ & $\begin{array}{c}\text { SOLIDS, } \\
\text { DIS- } \\
\text { SOLVED } \\
\text { (TONS } \\
\text { PER } \\
\text { AC-FT) }\end{array}$ & $\begin{array}{l}\text { ALUM - } \\
\text { INUM, } \\
\text { DIS- } \\
\text { SOLVED } \\
\text { (UG/L } \\
\text { AS AL) }\end{array}$ & $\begin{array}{l}\text { ANTI - } \\
\text { MONY, } \\
\text { DIS- } \\
\text { SOLVED } \\
\text { (UG/L } \\
\text { AS SB) }\end{array}$ & $\begin{array}{c}\text { ARSENIC } \\
\text { DIS- } \\
\text { SOLVED } \\
\text { (UG/L } \\
\text { AS AS) }\end{array}$ & $\begin{array}{l}\text { BARIUM, } \\
\text { DIS - } \\
\text { SOLVED } \\
\text { (UG/L } \\
\text { AS BA) }\end{array}$ & $\begin{array}{l}\text { BERYL- } \\
\text { LIUM, } \\
\text { DIS - } \\
\text { SOLVED } \\
\text { (UG/L } \\
\text { AS BE) }\end{array}$ & $\begin{array}{c}\text { BROMIDE } \\
\text { DIS - } \\
\text { SOLVED } \\
\text { (MG/L } \\
\text { AS BR) }\end{array}$ & $\begin{array}{c}\text { CADMIUM } \\
\text { DIS - } \\
\text { SOLVED } \\
\text { (UG/L } \\
\text { AS CD) }\end{array}$ \\
\hline $\begin{array}{c}\text { NOV } 1975 \\
12.996 \\
\text { AUG } 1996 \\
05 \ldots\end{array}$ & 569 & 550 & 0.75 & $\cdots$ & $<1$ & 3 & $<100$ & $<1$ & 0.12 & $<1.0$ \\
\hline DATE & $\begin{array}{l}\text { CHRO- } \\
\text { MIUM, } \\
\text { DIS - } \\
\text { SOLVED } \\
\text { (UG/L } \\
\text { AS CR) }\end{array}$ & $\begin{array}{c}\text { COBALT, } \\
\text { DIS - } \\
\text { SOLVED } \\
\text { (UG/L } \\
\text { AS CO) }\end{array}$ & $\begin{array}{l}\text { COPPER, } \\
\text { DIS- } \\
\text { SOLVED } \\
\text { (UG/L } \\
\text { AS CU) }\end{array}$ & $\begin{array}{l}\text { IRON, } \\
\text { DIS- } \\
\text { SOLVED } \\
\text { (UG/L } \\
\text { AS FE) }\end{array}$ & $\begin{array}{l}\text { LEAD, } \\
\text { DIS- } \\
\text { SOLVED } \\
\text { (UG/L } \\
\text { AS PB) }\end{array}$ & $\begin{array}{l}\text { MANGA - } \\
\text { NESE, } \\
\text { DIS- } \\
\text { SOLVED } \\
\text { (UG/L } \\
\text { AS MN) }\end{array}$ & $\begin{array}{c}\text { MERCURY } \\
\text { DIS - } \\
\text { SOLVED } \\
\text { (UG/L } \\
\text { AS HG) }\end{array}$ & $\begin{array}{l}\text { MOLYB - } \\
\text { DENUM, } \\
\text { DIS - } \\
\text { SOLVED } \\
\text { (UG/L } \\
\text { AS MO) }\end{array}$ & $\begin{array}{l}\text { NICKEL, } \\
\text { DIS - } \\
\text { SOLVED } \\
\text { (UG/L } \\
\text { AS NI) }\end{array}$ & $\begin{array}{c}\text { SILVER, } \\
\text { DIS - } \\
\text { SOLVED } \\
\text { (UG/L } \\
\text { AS AG) }\end{array}$ \\
\hline $\begin{array}{l}\text { NOV } 1975 \\
12.29 \\
\text { AUG } 1996\end{array}$ & $\cdots$ & $\cdots$ & 65 & 60 & ND & 30 & $<0.5$ & $<1$ & $\cdots$ & $\cdots$ \\
\hline $05 \ldots$ & 3 & $<1$ & 7 & 24 & $<1$ & 7 & $\cdots$ & 5 & 2 & $<1.0$ \\
\hline DATE & $\begin{array}{l}\text { SELE- } \\
\text { NIUM, } \\
\text { DIS- } \\
\text { SOLVED } \\
\text { (UG/L } \\
\text { AS SE) }\end{array}$ & $\begin{array}{l}\text { ZINC, } \\
\text { DIS- } \\
\text { SOLVED } \\
\text { (UG/I } \\
\text { AS ZN) }\end{array}$ & $\begin{array}{l}\text { URANIUM } \\
\text { NATURAL } \\
\text { DIS- } \\
\text { SOLVED } \\
\text { (UG/L } \\
\text { AS U) }\end{array}$ & $\begin{array}{c}\text { RADIUM } \\
226, \\
\text { DIS- } \\
\text { SOLVED, } \\
\text { RADON } \\
\text { METHOD } \\
\text { (PCI/L) }\end{array}$ & $\begin{array}{l}\text { GROSS } \\
\text { ALPHA, } \\
\text { DIS- } \\
\text { SOLVED } \\
\text { (UG/L } \\
\text { AS } \\
\text { U-NAT) }\end{array}$ & $\begin{array}{l}\text { GROSS } \\
\text { BETA, } \\
\text { DIS- } \\
\text { SOLVED } \\
\text { (PCI/L } \\
\text { AS SR/ } \\
\text { Y-90) }\end{array}$ & $\begin{array}{c}\text { GROSS } \\
\text { BETA, } \\
\text { DIS- } \\
\text { SOLVED } \\
\text { (PCI/L } \\
\text { AS } \\
\text { CS-137) }\end{array}$ & $\begin{array}{l}\text { POTAS- } \\
\text { SIUM } 40 \\
\text { TOTAL } \\
\text { (PCI/L) }\end{array}$ & $\begin{array}{l}\text { TRITIUM } \\
\text { TOTAL } \\
\text { (PCI/L) }\end{array}$ & $\begin{array}{c}\text { TRITIUM } \\
2 \text { SIGMA } \\
\text { WATER, } \\
\text { WHOLE, } \\
\text { TOTAL } \\
\text { (PCI/L) }\end{array}$ \\
\hline
\end{tabular}

NOV 1975

12

AUG 1996

$05 \ldots$.

$\begin{array}{rrrrrr}<1 & 590 & \ldots & \ldots & 10 & 6.8 \\ <1 & 47 & 25 & \ldots & \ldots & \ldots\end{array}$

$\begin{array}{cc}8.2 & 3.3 \\ - & -\end{array}$ 
WATER-QUALITY DATA

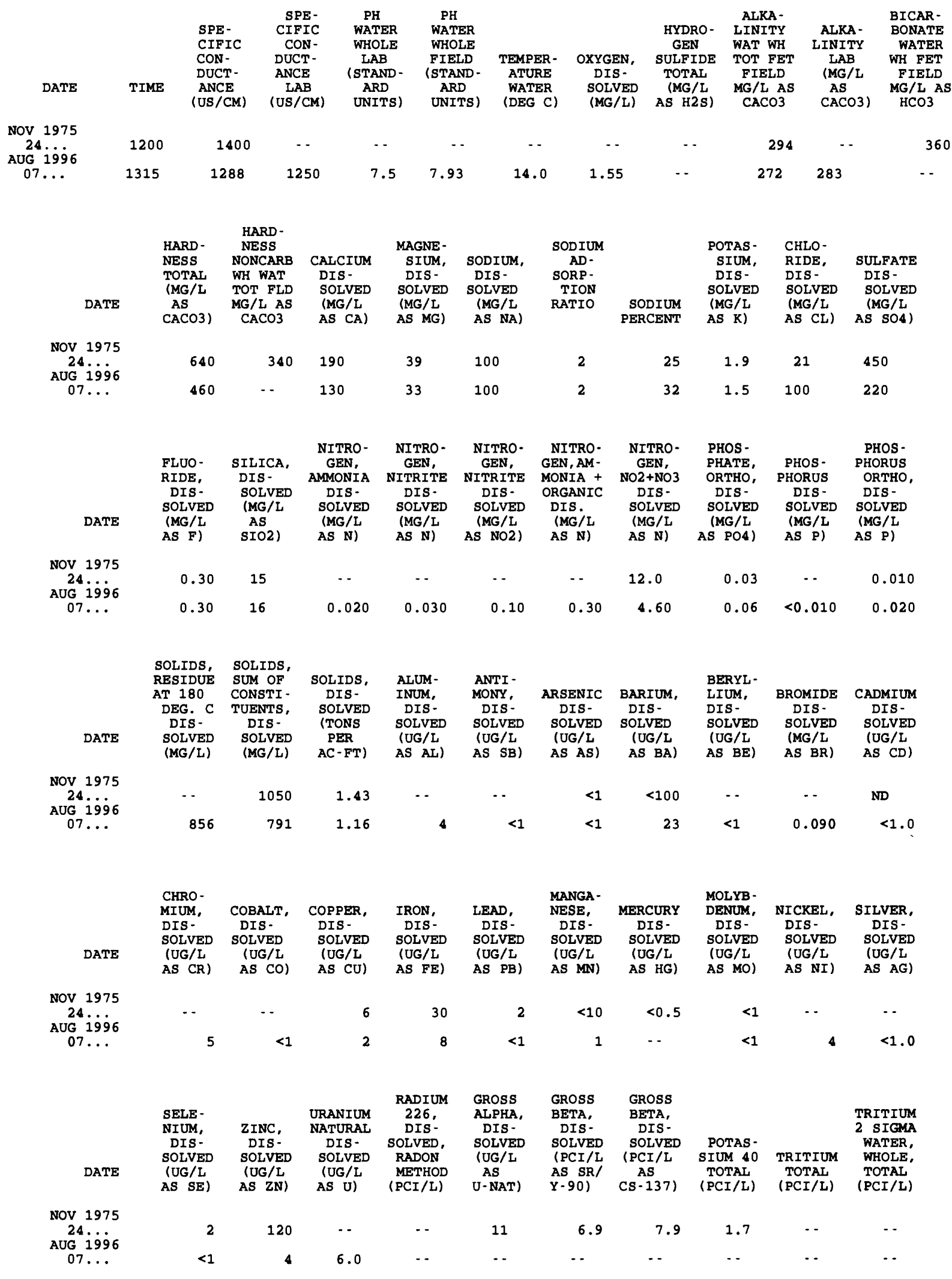


WATER-QUALITY DATA

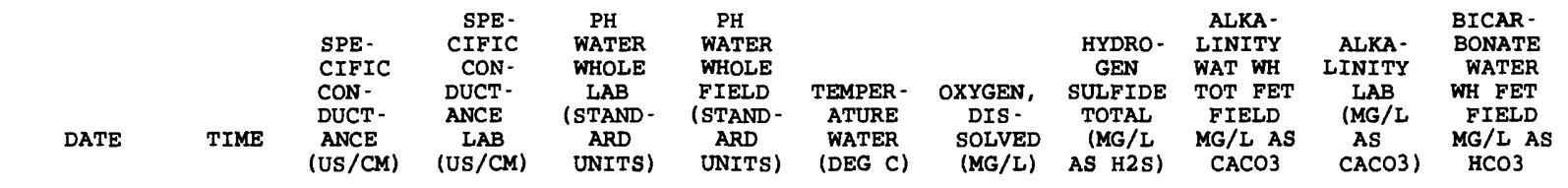

\begin{tabular}{|c|c|c|c|c|c|c|c|c|c|c|c|}
\hline $\begin{array}{l}\text { DEC } 1975 \\
0_{2} \ldots \dot{ } \\
\text { AUG } 1996\end{array}$ & 0900 & 3500 & - & $\cdots$ & $\cdots$ & $\cdots$ & $\cdots$ & $\cdots$ & 527 & - & 640 \\
\hline $06 \ldots$ & 1330 & 3440 & 3400 & 7.1 & 7.33 & 15.2 & 3.47 & . & - & 517 & $\cdots$ \\
\hline
\end{tabular}

DATE

DEC 1975

AUG 1996

$06 \ldots$

DEC 1975 $02 \ldots$ AUG 1996

$06 \ldots$

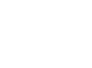

DATE

DEC 1975

AUG 19296

$06 \ldots$

DEC 1975

0200

$06 \ldots$

DEC 1975

$02 \ldots$

AUG 1996

$06 \ldots$

\begin{tabular}{|c|c|c|c|c|c|}
\hline $\begin{array}{l}\text { HARD - } \\
\text { NESS } \\
\text { TOTAL } \\
\text { (MG/L } \\
\text { AS }\end{array}$ & $\begin{array}{l}\text { HARD - } \\
\text { NESS } \\
\text { NONCARB } \\
\text { WH WAT } \\
\text { TOT FLD } \\
\text { MG/L AS }\end{array}$ & $\begin{array}{l}\text { CALCIUM } \\
\text { DIS- } \\
\text { SOLVED } \\
\text { (MG/L }\end{array}$ & $\begin{array}{l}\text { MAGNE- } \\
\text { SIUM, } \\
\text { DIS - } \\
\text { SOLVED } \\
\text { (MG/L }\end{array}$ & $\begin{array}{l}\text { SODIUM, } \\
\text { DIS - } \\
\text { SOLVED } \\
\text { (MG/L }\end{array}$ & $\begin{array}{c}\text { SODIUM } \\
\text { AD- } \\
\text { SORP- } \\
\text { TION } \\
\text { RATIO }\end{array}$ \\
\hline
\end{tabular}

CACO3) MG/L AS (MG/L (MG/L (MG/L

RATro

AS CA) AS MG) AS NA)

SODIUM

PERCENT

$\begin{array}{lll}\text { POTAS - } & \text { CHLO- } & \\ \text { SIUM, } & \text { RIDE, } & \text { SULFATE } \\ \text { DIS- } & \text { DIS- } & \text { DIS- } \\ \text { SOLVED } & \text { SOLVED } & \text { SOLVED } \\ \text { (MG/L } & \text { (MG/L } & \text { (MG/L } \\ \text { AS K) } & \text { AS CL) } & \text { AS SO4) }\end{array}$

$\begin{array}{cc}2000 & 1400 \\ 2200 & \ldots \\ & \\ & \\ \text { FLUO- } & \text { SILICA, } \\ \text { RIDE, } & \text { DIS- } \\ \text { DIS- } & \text { SOLVED } \\ \text { SOLVED } & \text { (MG/L } \\ \text { (MG/L } & \text { AS } \\ \text { AS F) } & \text { SIO2) }\end{array}$

320

$280 \quad 230$

2

20

$\begin{array}{ll}3.2 & 40 \\ 3.7 & 16\end{array}$

1700

$270 \quad 360$

160

\begin{tabular}{|c|c|c|c|c|}
\hline $\begin{array}{l}\text { NITRO- } \\
\text { GEN, } \\
\text { AMMONIA }\end{array}$ & $\begin{array}{c}\text { NITRO- } \\
\text { GEN, } \\
\text { NITRITE }\end{array}$ & $\begin{array}{c}\text { NITRO- } \\
\text { GEN, } \\
\text { NITRITE }\end{array}$ & $\begin{array}{l}\text { NITRO- } \\
\text { GEN, AM- } \\
\text { MONIA + }\end{array}$ & $\begin{array}{c}\text { NITRO- } \\
\text { GEN, } \\
\text { NO2+NO3 }\end{array}$ \\
\hline $\begin{array}{l}\text { DIS- } \\
\text { SOLVED } \\
\text { (MG/L }\end{array}$ & $\begin{array}{l}\text { DIS - } \\
\text { SOLVED } \\
\text { (MG/L }\end{array}$ & $\begin{array}{l}\text { DIS- } \\
\text { SOLVED } \\
\text { (MG/L }\end{array}$ & $\begin{array}{l}\text { ORGANIC } \\
\text { DIS. } \\
\text { (MG/L }\end{array}$ & $\begin{array}{l}\text { DIS- } \\
\text { SOLVED } \\
\text { (MG/L }\end{array}$ \\
\hline & & & & \\
\hline
\end{tabular}

\begin{tabular}{|c|c|c|}
\hline $\begin{array}{l}\text { PHOS - } \\
\text { PHATE, } \\
\text { ORTHO, } \\
\text { DIS - } \\
\text { SOLVED } \\
\text { (MG/L }\end{array}$ & $\begin{array}{c}\text { PHOS - } \\
\text { PHORUS } \\
\text { DIS - } \\
\text { SOLVED } \\
\text { (MG/L }\end{array}$ & $\begin{array}{c}\text { PHOS - } \\
\text { PHORUS } \\
\text { ORTHO } \\
\text { DIS- } \\
\text { SOLVED } \\
\text { (MG/L }\end{array}$ \\
\hline S PO4) & AS P) & AS $\mathrm{P})$ \\
\hline
\end{tabular}

$\begin{array}{ll}2.0 & 14 \\ 1.8 & 14\end{array}$

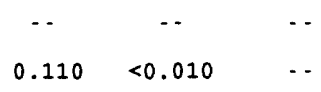
.. $\quad 0.220$
$0.30 \quad 0.150$

0.06

-

0.020

$0.06<0.010$

0.020

SOLIDS, SOLIDS,

RESIDU SOLIDS

SUM OF

AT 180 CONSTI-

DIS - DIS -

SOLVED SOLVED

SOLIDS,

INUM, MONY, ARSENIC BARIUM,

DIS- DIS -

SOLVED SOLVED SOLVED SOLVED

$\begin{array}{llll}\text { (UG/L } & \text { (UG } / L & \text { (UG } / L & \text { (UG } / L \\ \text { AS AL) } & \text { AS SB) } & \text { AS AS) } & \text { AS BA) }\end{array}$

AC-FT) AS AL)

BERYL- BROMIDE CADMIUM

$\begin{array}{ccc}\text { LIUM, } & \text { BROMIDE } & \text { CADMIUM } \\ \text { DIS- } & \text { DIS- } & \text { DIS- }\end{array}$

SOLVED SOLVED SOLVED

(UG/L (MG/L (UG/L

AS BE) AS BR) AS CD)

-. 2910

$\begin{array}{rrrrr}3.95 & \cdots & \cdots & <1 & <100 \\ 4.80 & 6 & <3 & <1 & 25\end{array}$
-
$<3$

- $\quad<2.0$

0.19

$<3.0$

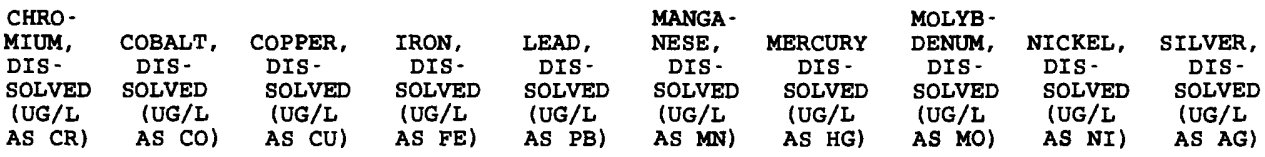

\begin{tabular}{|c|c|c|c|c|c|c|c|c|c|}
\hline $\begin{array}{l}\text { CHRO- } \\
\text { MIUM, } \\
\text { DIS - } \\
\text { SOLVED } \\
\text { (UG/L }\end{array}$ & $\begin{array}{l}\text { COBALT, } \\
\text { DIS - } \\
\text { SOLVED } \\
\text { (UG/L }\end{array}$ & $\begin{array}{l}\text { COPPER, } \\
\text { DIS - } \\
\text { SOLVED } \\
\text { (UG/L }\end{array}$ & $\begin{array}{l}\text { IRON, } \\
\text { DIS- } \\
\text { SOLVED } \\
\text { (UG/L }\end{array}$ & $\begin{array}{l}\text { LEAD, } \\
\text { DIS- } \\
\text { SOLVED } \\
\text { (UG/L }\end{array}$ & $\begin{array}{l}\text { MANGA - } \\
\text { NESE, } \\
\text { DIS- } \\
\text { SOLVED } \\
\text { (UG/L }\end{array}$ & $\begin{array}{c}\text { MERCURY } \\
\text { DIS - } \\
\text { SOLVED } \\
\text { (UG/L } \\
\text { ASG }\end{array}$ & $\begin{array}{l}\text { MOLYB - } \\
\text { DENUM, } \\
\text { DIS - } \\
\text { SOLVED } \\
\text { (UG/L }\end{array}$ & $\begin{array}{l}\text { NICKEL, } \\
\text { DIS - } \\
\text { SOLVED } \\
\text { (UG/L }\end{array}$ & $\begin{array}{c}\text { SILVER, } \\
\text { DIS - } \\
\text { SOLVED } \\
\text { (UG/L }\end{array}$ \\
\hline
\end{tabular}




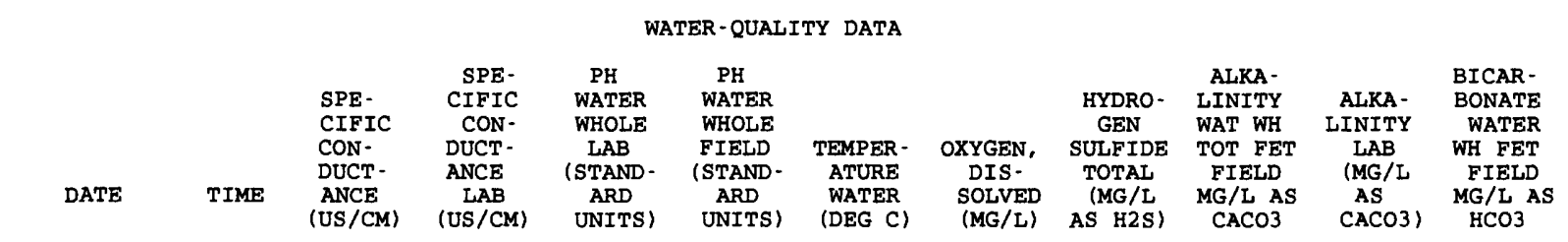

$800 \quad--$

$\begin{array}{ll} & \text { HARD - } \\ \text { HARD- } & \text { NESS } \\ \text { NESS } & \text { NONCARB } \\ \text { TOTAL } & \text { WH WAT } \\ \text { (MG/L } & \text { TOT FLD } \\ \text { AS } & \text { MG/L AS } \\ \text { CACO3) } & \text { CACO3 }\end{array}$

$\begin{array}{cccc} & \text { MAGNE- } & \text { SODIUM } \\ \text { CALCIUM } & \text { SIUM, } & \text { SODIUM, } & \text { AD- } \\ \text { DIS- } & \text { DIS- } & \text { DIS- } & \text { SORP- } \\ \text { SOLVED } & \text { SOLVED } & \text { SOLVED } & \text { TION } \\ \text { (MG/L } & \text { (MG/L } & \text { (MG/L } & \text { RATIO } \\ \text { AS CA) } & \text { AS MG) } & \text { AS NA) } & \end{array}$

$\begin{array}{rcll} & \text { POTAS - } & \text { CHLO- } & \\ & \text { SIUM, } & \text { RIDE, } & \text { SULFATE } \\ & \text { DIS- } & \text { DIS- } & \text { DIS- } \\ & \text { SOLVED } & \text { SOLVED } & \text { SOLVED } \\ \text { SODIUM } & \text { (MG/L } & \text { (MG/L } & \text { (MG/L } \\ \text { PERCENT } & \text { AS K) } & \text { AS CL) } & \text { AS SO4) }\end{array}$

$$
\begin{gathered}
\text { DEC } 1975 \\
06.996 \\
\text { AUG } 1996 \\
21 \ldots
\end{gathered}
$$

$\begin{array}{cc}330 & \ldots \\ 260 & \ldots \\ & \\ & \\ & \\ \text { FLUO- } & \text { SILICA, } \\ \text { RIDE, } & \text { DIS- } \\ \text { DIS- } & \text { SOLVED } \\ \text { SOLVED } & \text { (MG/L } \\ \text { (MG/L } & \text { AS } \\ \text { AS F) } & \text { SIO2) } \\ & \end{array}$

$\begin{array}{lll}89 & 27 & 38 \\ 70 & 21 & 32\end{array}$

$\begin{array}{ll}0.9 & 20 \\ 0.9 & 21\end{array}$

$\begin{array}{ll}1.4 & 19 \\ 1.1 & 22\end{array}$

84

70

$$
\begin{array}{ll}
0.50 & 12 \\
0.60 & 10
\end{array}
$$

NITRO-
GEN,
AMMONIA
DIS-
SOLVED
(MG/L
AS N)

NITRO-

NITRO -

NITRO- NITRONITRITE NITRITE MONIA + NO2+NO3 DIS- DIS - ORGANIC DIS SOLVED SOLVED DIS. SOLVED (MG/L (MG/I DIS. AS N) AS NO2) AS N) (MG/L
AS N)

PHOS -

PHOS - PHOS PHATE, PHOS - PHORUS ORTHO, PHORUS ORTHO, DIS- DIS - DIS SOLVED SOLVED SOLVED (MG/I (MG/I (MG/I $\begin{array}{ccc}(\mathrm{MG} / \mathrm{L} & (\mathrm{MG} / \mathrm{L} & (\mathrm{MG} / \mathrm{L} \\ \text { AS PO4) } & \text { AS P) } & \text { AS P) }\end{array}$

DEC 1975 AUG 1966

SOLIDS, SOLIDS, RESIDUE SUM OF RTS 180 CONSTI AT 180 CONSTI DEG. C TUENTS, SOLVED SOLVED $\begin{array}{ll}\text { (MG/L) } & \text { (MG/L) }\end{array}$

$\begin{array}{cc}\text { SOLIDS, } & \text { ALUM- } \\ \text { DIS- } & \text { INUM, } \\ \text { SOLVED } & \text { DIS- } \\ \text { (TONS } & \text { SOLVED } \\ \text { PER } & \text { (UG/L }\end{array}$

ANTI -

MONY, ARSENIC BARIUM, MIS DOLVED SOLVED (UG/L
AS SB)

UG/L (UG/I

AS AS) AS BA)
BERYL -

UIUM, BROMIDE CADMIUM DIS - DIS - DIS $\begin{array}{lcc}\text { DIS - } & \text { DIS - } & \text { DIS - } \\ \text { SOLVED } & \text { SOLVED } & \text { SOLVED }\end{array}$ (UG/L (MG/L (UG/L AS BE) AS BR) AS CD)
DEC 1975

AUG 1966

$21 \ldots$.

DEC 1975

OUG 1996

$21 \ldots$

DATE

$\begin{array}{ll}\cdots & 470 \\ 391 & 379\end{array}$

\begin{abstract}
0.64
\end{abstract}
0.53

\begin{tabular}{|c|c|c|c|c|c|c|c|c|c|}
\hline $\begin{array}{l}\text { CHRO- } \\
\text { MIUM, } \\
\text { DIS- } \\
\text { SOLVED } \\
\text { (UG/L } \\
\text { AS CR) }\end{array}$ & $\begin{array}{l}\text { COBALT, } \\
\text { DIS - } \\
\text { SOLVED } \\
\text { (UG/L } \\
\text { AS CO) }\end{array}$ & $\begin{array}{l}\text { COPPER, } \\
\text { DIS - } \\
\text { SOLVED } \\
\text { (UG/L } \\
\text { AS CU) }\end{array}$ & $\begin{array}{l}\text { IRON, } \\
\text { DIS- } \\
\text { SOLVED } \\
\text { (UG/L } \\
\text { AS FE) }\end{array}$ & $\begin{array}{l}\text { LEAD, } \\
\text { DIS- } \\
\text { SOLVED } \\
\text { (UG/L } \\
\text { AS PB) }\end{array}$ & $\begin{array}{l}\text { MANGA- } \\
\text { NESE, } \\
\text { DIS- } \\
\text { SOLVED } \\
\text { (UG/L } \\
\text { AS MN) }\end{array}$ & $\begin{array}{c}\text { MERCURY } \\
\text { DIS - } \\
\text { SOLVED } \\
\text { (UG/L } \\
\text { AS HG) }\end{array}$ & $\begin{array}{l}\text { MOLYB- } \\
\text { DENUM, } \\
\text { DIS- } \\
\text { SOLVED } \\
\text { (UG/L } \\
\text { AS MO) }\end{array}$ & $\begin{array}{l}\text { NICKEL, } \\
\text { DIS - } \\
\text { SOLVED } \\
\text { (UG/L } \\
\text { AS NI) }\end{array}$ & $\begin{array}{c}\text { SILVER, } \\
\text { DIS - } \\
\text { SOLVED } \\
\text { (UG/L } \\
\text { AS AG) }\end{array}$ \\
\hline
\end{tabular}

$\begin{array}{ll}\cdots & \cdots \\ 4 & <1\end{array}$

\begin{tabular}{|c|c|c|c|c|c|c|c|c|c|c|}
\hline DATE & $\begin{array}{l}\text { SELE- } \\
\text { NIUM, } \\
\text { DIS- } \\
\text { SOLVED } \\
\text { (UG/L } \\
\text { AS SE) }\end{array}$ & $\begin{array}{c}\text { ZINC, } \\
\text { DIS- } \\
\text { SOLVED } \\
\text { (UG/L } \\
\text { AS ZN) }\end{array}$ & $\begin{array}{l}\text { URANIUM } \\
\text { NATURAL } \\
\text { DIS- } \\
\text { SOLVED } \\
\text { (UG/L } \\
\text { AS U) }\end{array}$ & $\begin{array}{c}\text { RADIUM } \\
226, \\
\text { DIS- } \\
\text { SOLVED, } \\
\text { RADON } \\
\text { METHOD } \\
\text { (PCI/L) }\end{array}$ & $\begin{array}{c}\text { GROSS } \\
\text { ALPHA, } \\
\text { DIS- } \\
\text { SOLVED } \\
\text { (UG/L } \\
\text { AS } \\
\text { U-NAT) }\end{array}$ & $\begin{array}{l}\text { GROSS } \\
\text { BETA, } \\
\text { DIS- } \\
\text { SOLVED } \\
\text { (PCI/L } \\
\text { AS SR/ } \\
\text { Y-90) }\end{array}$ & $\begin{array}{c}\text { GROSS } \\
\text { BETA, } \\
\text { DIS- } \\
\text { SOLVED } \\
\text { (PCI/L } \\
\text { AS } \\
\text { CS-137) }\end{array}$ & $\begin{array}{l}\text { POTAS- } \\
\text { SIUM } 40 \\
\text { TOTAL } \\
(\text { PCI } / L)\end{array}$ & $\begin{array}{l}\text { TRITIUM } \\
\text { TOTAL } \\
\text { (PCI/L) }\end{array}$ & $\begin{array}{c}\text { TRITIUM } \\
2 \text { SIGMA } \\
\text { WATER, } \\
\text { WHOLE, } \\
\text { TOTAL } \\
(\text { PCI/L) }\end{array}$ \\
\hline $\begin{array}{c}\text { DEC } 1975 \\
06706 \\
\text { AUG } 1996\end{array}$ & $<1$ & 30 & $\cdots$ & $\cdots$ & 10 & 5.9 & 7.2 & 1.3 & -- & $\cdots$ \\
\hline $21 \ldots$ & $<1$ & $<1$ & 2.0 & $\cdots$ & - & $\cdots$ & $\cdots$ & - & 48 & 3.8 \\
\hline
\end{tabular}

\begin{abstract}
AS BE
\end{abstract}

-

$$
\begin{array}{cc}
\cdots & <2.0 \\
0.11 & <1.0
\end{array}
$$$$
<1
$$ 
WATER-QUALITY DATA

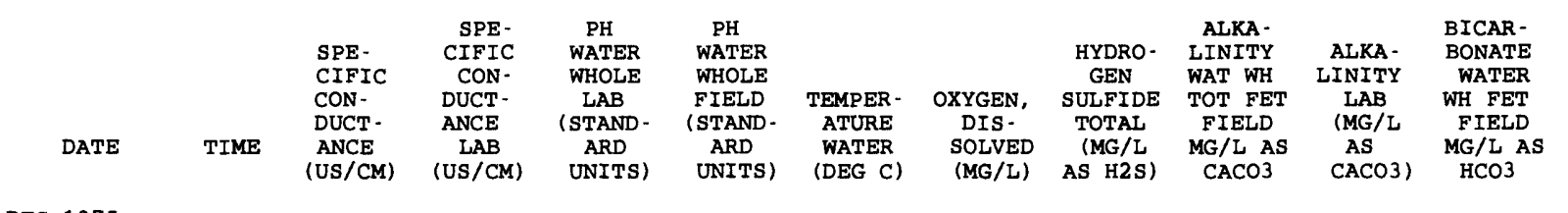

\begin{tabular}{|c|c|c|c|c|c|c|c|c|c|c|c|}
\hline $\begin{array}{l}\text { DEC } 1975 \\
06.206 \\
\text { SEP } 1996\end{array}$ & 1150 & 1550 & $\cdots$ & $\cdots$ & $\cdots$ & $\cdots$ & $\cdots$ & $\cdots$ & -- & $\cdots$ & 500 \\
\hline $03 \ldots$ & 1000 & 1347 & 1330 & 7.5 & 7.52 & 14.6 & 0.34 & $<0.002$ & 466 & 418 & $\ldots$ \\
\hline
\end{tabular}

\begin{tabular}{|c|c|c|c|c|c|c|c|c|c|c|}
\hline DATE & $\begin{array}{l}\text { HARD - } \\
\text { NESS } \\
\text { TOTAL } \\
\text { (MG/L } \\
\text { AS } \\
\text { CACO3) }\end{array}$ & $\begin{array}{l}\text { HARD- } \\
\text { NESS } \\
\text { NONCARB } \\
\text { WH WAT } \\
\text { TOT FLD } \\
\text { MG/L AS } \\
\text { CACO3 }\end{array}$ & $\begin{array}{l}\text { CALCIUM } \\
\text { DIS- } \\
\text { SOLVED } \\
\text { (MG/L } \\
\text { AS CA) }\end{array}$ & $\begin{array}{l}\text { MAGNE- } \\
\text { SIUM, } \\
\text { DIS - } \\
\text { SOIVED } \\
\text { (MG/I } \\
\text { AS MG) }\end{array}$ & $\begin{array}{c}\text { SODIUM, } \\
\text { DIS - } \\
\text { SOLVED } \\
\text { (MG/L } \\
\text { AS NA) }\end{array}$ & $\begin{array}{c}\text { SODIUM } \\
\text { AD- } \\
\text { SORP- } \\
\text { TION } \\
\text { RATIO }\end{array}$ & $\begin{array}{r}\text { SODIUM } \\
\text { PERCENT }\end{array}$ & $\begin{array}{l}\text { POTAS - } \\
\text { SIUM, } \\
\text { DIS - } \\
\text { SOLVED } \\
\text { (MG/L } \\
\text { AS K) }\end{array}$ & $\begin{array}{l}\text { CHLO- } \\
\text { RIDE, } \\
\text { DIS - } \\
\text { SOLVED } \\
\text { (MG/L } \\
\text { AS CL) }\end{array}$ & $\begin{array}{c}\text { SULFATE } \\
\text { DIS- } \\
\text { SOLVED } \\
\text { (MG/L } \\
\text { AS SO4) }\end{array}$ \\
\hline $\begin{array}{l}\text { DEC } 1975 \\
06.9196 \\
\text { SEP } 1996\end{array}$ & 610 & $\cdots$ & 120 & 75 & 150 & 3 & 35 & 3.9 & 11 & 450 \\
\hline $03 \ldots$ & 470 & $\cdots$ & 77 & 67 & 120 & 2 & 36 & 2.9 & 21 & 290 \\
\hline DATE & $\begin{array}{l}\text { FLUO- } \\
\text { RIDE, } \\
\text { DIS- } \\
\text { SOLVED } \\
\text { (MG/L } \\
\text { AS F) }\end{array}$ & $\begin{array}{l}\text { SILICA, } \\
\text { DIS- } \\
\text { SOLVED } \\
\text { (MG/L } \\
\text { AS } \\
\text { SIO2) }\end{array}$ & $\begin{array}{c}\text { NITRO- } \\
\text { GEN, } \\
\text { AMMONIA } \\
\text { DIS - } \\
\text { SOLVED } \\
\text { (MG/L } \\
\text { AS N) }\end{array}$ & $\begin{array}{c}\text { NITRO- } \\
\text { GEN, } \\
\text { NITRITE } \\
\text { DIS- } \\
\text { SOLVED } \\
\text { (MG/L } \\
\text { AS N) }\end{array}$ & $\begin{array}{c}\text { NITRO- } \\
\text { GEN, } \\
\text { NITRITE } \\
\text { DIS - } \\
\text { SOLVED } \\
\text { (MG/L } \\
\text { AS NO2) }\end{array}$ & $\begin{array}{l}\text { NITRO- } \\
\text { GEN, AM- } \\
\text { MONIA + } \\
\text { ORGANIC } \\
\text { DIS. } \\
\text { (MG/L } \\
\text { AS N) }\end{array}$ & $\begin{array}{c}\text { NITRO- } \\
\text { GEN, } \\
\text { NO2+NO3 } \\
\text { DIS- } \\
\text { SOLVED } \\
\text { (MG/L } \\
\text { AS N) }\end{array}$ & $\begin{array}{c}\text { PHOS- } \\
\text { PHATE, } \\
\text { ORTHO, } \\
\text { DIS - } \\
\text { SOLVED } \\
\text { (MG/L } \\
\text { AS PO4) }\end{array}$ & $\begin{array}{c}\text { PHOS - } \\
\text { PHORUS } \\
\text { DIS - } \\
\text { SOLVED } \\
\text { (MG/I } \\
\text { AS P) }\end{array}$ & $\begin{array}{l}\text { PHOS- } \\
\text { PHORUS } \\
\text { ORTHO, } \\
\text { DIS- } \\
\text { SOLVED } \\
\text { (MG/L } \\
\text { AS P) }\end{array}$ \\
\hline $\begin{array}{l}\text { DEC } 1975 \\
06 \ldots \\
\text { SEP } 1996\end{array}$ & 1.5 & 17 & $\cdots$ & 0.020 & 0.07 & $\cdots$ & 3.10 & 0.12 & $\cdots$ & 0.040 \\
\hline DATE & $\begin{array}{l}\text { SOLIDS, } \\
\text { RESIDUE } \\
\text { AT } 180 \\
\text { DEG. C } \\
\text { DIS - } \\
\text { SOLVED } \\
(\mathrm{MG} / \mathrm{L})\end{array}$ & $\begin{array}{c}\text { SOLIDS, } \\
\text { SUM OF } \\
\text { CONSTI - } \\
\text { TUENTS, } \\
\text { DIS - } \\
\text { SOLVED } \\
\text { (MG } / L)\end{array}$ & $\begin{array}{l}\text { SOLIDS, } \\
\text { DIS - } \\
\text { SOLVED } \\
\text { (TONS } \\
\text { PER } \\
\text { AC-FT) }\end{array}$ & $\begin{array}{l}\text { ALUM- } \\
\text { INUM, } \\
\text { DIS- } \\
\text { SOLVED } \\
\text { (UG/L } \\
\text { AS AL) }\end{array}$ & $\begin{array}{l}\text { ANTI - } \\
\text { MONY, } \\
\text { DIS - } \\
\text { SOLVED } \\
\text { (UG/L } \\
\text { AS SB) }\end{array}$ & $\begin{array}{c}\text { ARSENIC } \\
\text { DIS - } \\
\text { SOLVED } \\
\text { (UG/L } \\
\text { AS AS) }\end{array}$ & $\begin{array}{c}\text { BARIUM, } \\
\text { DIS- } \\
\text { SOLVED } \\
\text { (UG/L } \\
\text { AS BA) }\end{array}$ & $\begin{array}{l}\text { BERYL- } \\
\text { LIUM, } \\
\text { DIS- } \\
\text { SOLVED } \\
\text { (UG/L } \\
\text { AS BE) }\end{array}$ & $\begin{array}{c}\text { BROMIDE } \\
\text { DIS - } \\
\text { SOLVED } \\
\text { (MG/L } \\
\text { AS BR) }\end{array}$ & $\begin{array}{c}\text { CADMIUM } \\
\text { DIS - } \\
\text { SOLVED } \\
\text { (UG/L } \\
\text { AS CD) }\end{array}$ \\
\hline $\begin{array}{c}\text { DEC } 1975 \\
06.2 \\
\text { SEP } 1996\end{array}$ & $\cdots$ & 1090 & 1.48 & $\cdots$ & $\cdots$ & $<1$ & $<100$ & $\cdots$ & $\cdots$ & 3.0 \\
\hline DATE & $\begin{array}{l}\text { CHRO- } \\
\text { MIUM, } \\
\text { DIS- } \\
\text { SOLVED } \\
\text { (UG/L } \\
\text { AS CR) }\end{array}$ & $\begin{array}{l}\text { COBALT, } \\
\text { DIS - } \\
\text { SOLVED } \\
\text { (UG/L } \\
\text { AS CO) }\end{array}$ & $\begin{array}{l}\text { COPPER, } \\
\text { DIS - } \\
\text { SOLVED } \\
\text { (UG/L } \\
\text { AS CU) }\end{array}$ & $\begin{array}{l}\text { IRON, } \\
\text { DIS- } \\
\text { SOLVED } \\
\text { (UG/L } \\
\text { AS FE) }\end{array}$ & $\begin{array}{l}\text { LEAD, } \\
\text { DIS- } \\
\text { SOLVED } \\
\text { (UG/L } \\
\text { AS PB) }\end{array}$ & $\begin{array}{l}\text { MANGA- } \\
\text { NESE, } \\
\text { DIS- } \\
\text { SOLVED } \\
\text { (UG/L } \\
\text { AS MN) }\end{array}$ & $\begin{array}{c}\text { MERCURY } \\
\text { DIS - } \\
\text { SOLVED } \\
\text { (UG/L } \\
\text { AS HG) }\end{array}$ & $\begin{array}{l}\text { MOLYB - } \\
\text { DENUM, } \\
\text { DIS- } \\
\text { SOLVED } \\
\text { (UG/L } \\
\text { AS MO) }\end{array}$ & $\begin{array}{l}\text { NICKEL, } \\
\text { DIS - } \\
\text { SOLVED } \\
\text { (UG/L } \\
\text { AS NI) }\end{array}$ & $\begin{array}{c}\text { SILVER, } \\
\text { DIS- } \\
\text { SOLVED } \\
\text { (UG/L } \\
\text { AS AG) }\end{array}$ \\
\hline $\begin{array}{l}\text { DEC } 1975 \\
06.29 \\
\text { SEP } 1966\end{array}$ & $\cdots$ & $\cdots$ & 19 & 90 & 10 & 30 & $<0.5$ & 8 & $\cdots$ & $\cdots$ \\
\hline DATE & $\begin{array}{l}\text { SELE - } \\
\text { NIUM, } \\
\text { DIS- } \\
\text { SOLVED } \\
\text { (UG/L } \\
\text { AS SE) }\end{array}$ & $\begin{array}{l}\text { ZINC, } \\
\text { DIS - } \\
\text { SOLVED } \\
\text { (UG/L } \\
\text { AS ZN) }\end{array}$ & $\begin{array}{l}\text { URANIUM } \\
\text { NATURAL } \\
\text { DIS - } \\
\text { SOLVED } \\
\text { (UG/L } \\
\text { AS U) }\end{array}$ & $\begin{array}{l}\text { RADIUM } \\
226, \\
\text { DIS- } \\
\text { SOLVED, } \\
\text { RADON } \\
\text { METHOD } \\
\text { (PCI/L) }\end{array}$ & $\begin{array}{l}\text { GROSS } \\
\text { ALPHA, } \\
\text { DIS - } \\
\text { SOLVED } \\
\text { (UG/I } \\
\text { AS } \\
\text { U-NAT) }\end{array}$ & $\begin{array}{l}\text { GROSS } \\
\text { BETA, } \\
\text { DIS - } \\
\text { SOLVED } \\
(P C I / L \\
\text { AS SR/ } \\
\text { Y-90) }\end{array}$ & $\begin{array}{c}\text { GROSS } \\
\text { BETA, } \\
\text { DIS- } \\
\text { SOLVED } \\
\text { (PCI/L } \\
\text { AS } \\
\text { CS-137) }\end{array}$ & $\begin{array}{l}\text { POTAS- } \\
\text { SIUM } 40 \\
\text { TOTAL } \\
(\mathrm{PCI} / \mathrm{L})\end{array}$ & $\begin{array}{l}\text { TRITIUM } \\
\text { TOTAL } \\
\text { (PCI/L) }\end{array}$ & $\begin{array}{c}\text { TRITIUM } \\
2 \text { SIGMA } \\
\text { WATER, } \\
\text { WHOLE, } \\
\text { TOTAL } \\
(\text { PCI/L) }\end{array}$ \\
\hline $\begin{array}{l}\text { DEC } 1975 \\
06 . . . \\
\text { SEP } 1996\end{array}$ & 4 & 150 & $\cdots$ & $\cdots$ & $\cdots$ & - & $\cdots$ & 2.7 & $\cdots$ & $\cdots$ \\
\hline 03. & 1 & 27 & 21 & $\cdots$ & $\cdots$ & $\cdots$ & $\cdots$ & - & 87 & 5.8 \\
\hline
\end{tabular}


WATER-QUALITY DATA

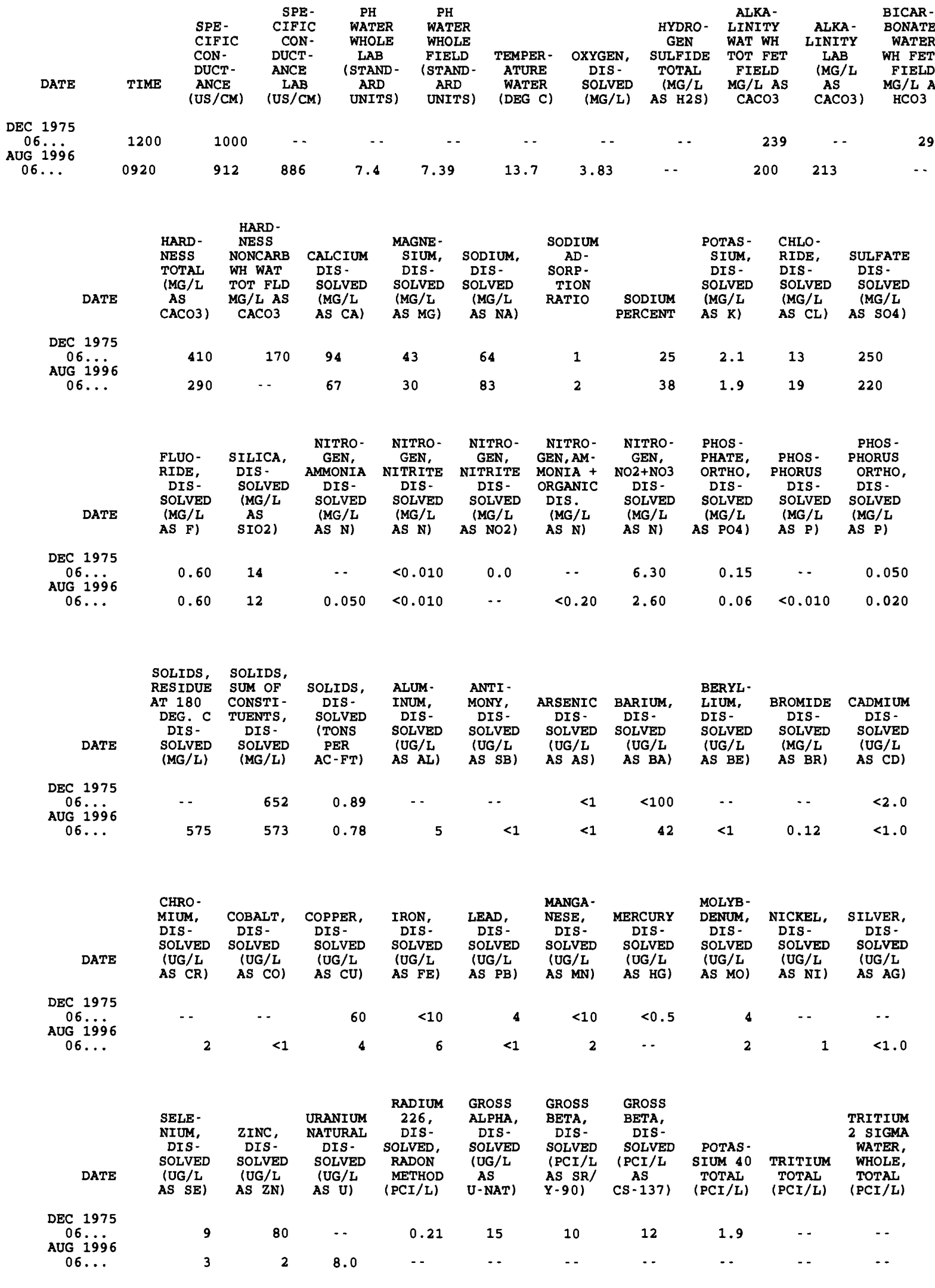




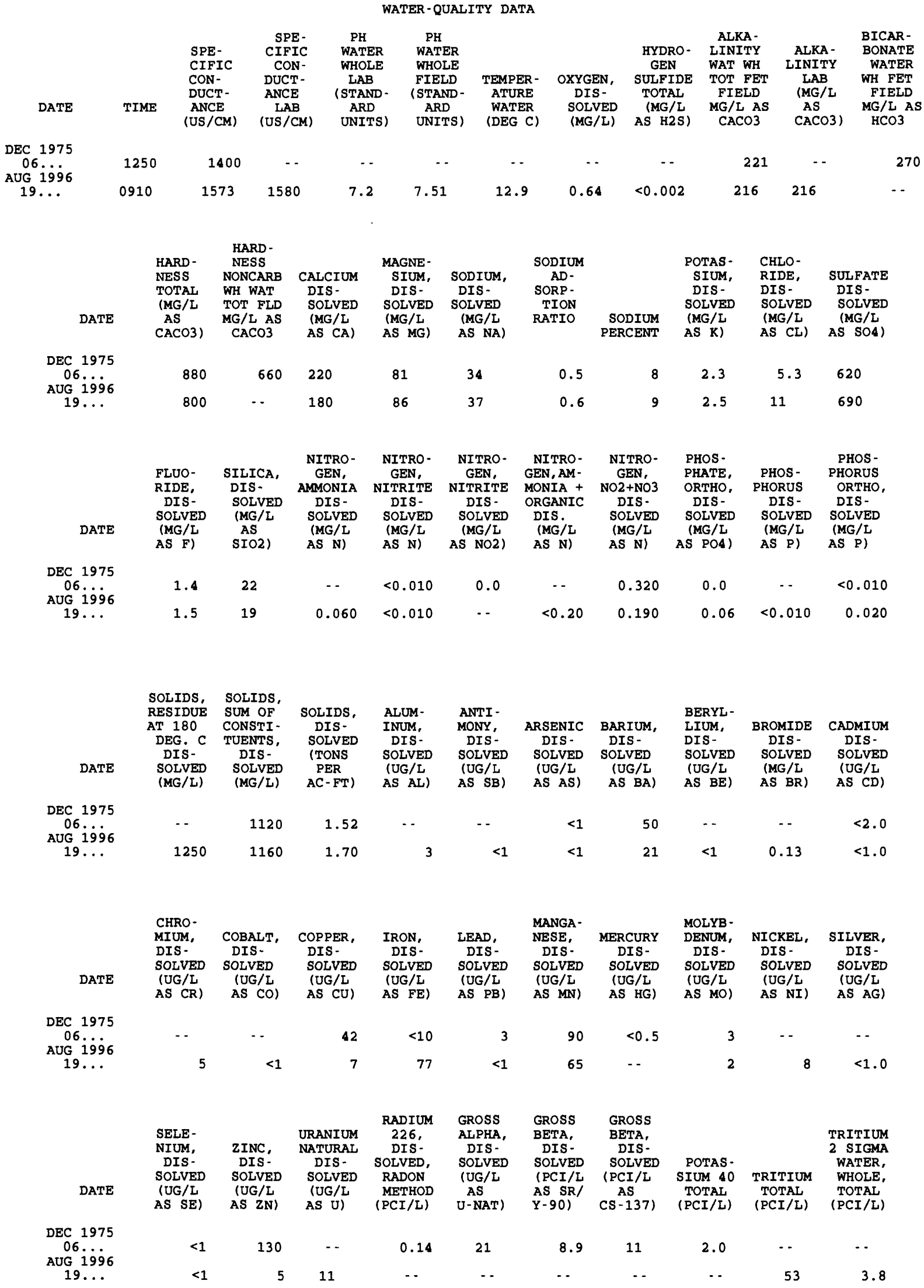


WATER-QUALITY DATA

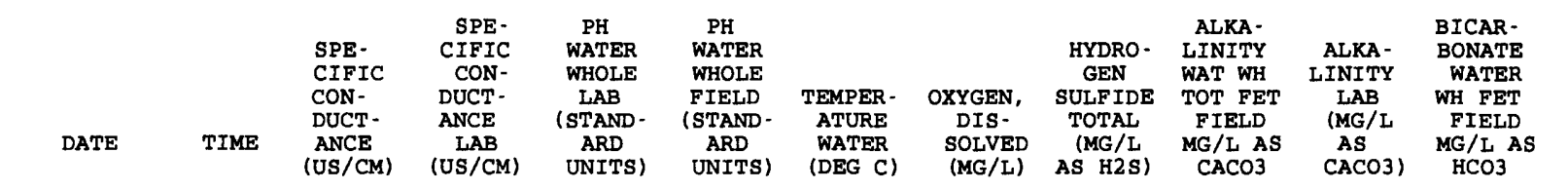

JAN 1976

AUG 1996

1030

600

- -

․

6.

43

$-$

350

$08 \ldots$

1400

$638 \quad 627$

7.3

7.71

$15.2 \quad 3.43$

344

298

\begin{tabular}{|c|c|c|c|c|c|c|c|c|c|c|}
\hline DATE & $\begin{array}{l}\text { HARD - } \\
\text { NESS } \\
\text { TOTAL } \\
\text { (MG/L } \\
\text { AS } \\
\text { CACO3) }\end{array}$ & $\begin{array}{l}\text { HARD- } \\
\text { NESS } \\
\text { NONCARB } \\
\text { WH WAT } \\
\text { TOT FLD } \\
\text { MG/L AS } \\
\text { CACO3 }\end{array}$ & $\begin{array}{l}\text { CALCIUM } \\
\text { DIS- } \\
\text { SOLVED } \\
\text { (MG/L } \\
\text { AS CA) }\end{array}$ & $\begin{array}{l}\text { MAGNE- } \\
\text { SIUM, } \\
\text { DIS - } \\
\text { SOLVED } \\
\text { (MG/L } \\
\text { AS MG) }\end{array}$ & $\begin{array}{l}\text { SODIUM, } \\
\text { DIS - } \\
\text { SOLVED } \\
\text { (MG/L } \\
\text { AS NA) }\end{array}$ & $\begin{array}{l}\text { SODIUM } \\
\text { AD- } \\
\text { SORP- } \\
\text { TION } \\
\text { RATIO }\end{array}$ & $\begin{array}{l}\text { SODIUM } \\
\text { PERCENT }\end{array}$ & $\begin{array}{l}\text { POTAS- } \\
\text { SIUM, } \\
\text { DIS- } \\
\text { SOLVED } \\
\text { (MG/L } \\
\text { AS K) }\end{array}$ & $\begin{array}{l}\text { CHLO - } \\
\text { RIDE, } \\
\text { DIS - } \\
\text { SOLVED } \\
\text { (MG/L } \\
\text { AS CL) }\end{array}$ & $\begin{array}{l}\text { SULFATE } \\
\text { DIS- } \\
\text { SOLVED } \\
\text { (MG/L } \\
\text { AS SO4) }\end{array}$ \\
\hline $\begin{array}{c}\text { JAN } 1976 \\
21 \ldots 9 \\
\text { AUG } 1996 \\
08 \ldots\end{array}$ & 280 & -- & 62 & 30 & 24 & 0.6 & 16 & 1.8 & 2.2 & 52 \\
\hline DATE & $\begin{array}{l}\text { FLUO- } \\
\text { RIDE, } \\
\text { DIS- } \\
\text { SOLVED } \\
\text { (MG/L } \\
\text { AS F) }\end{array}$ & $\begin{array}{l}\text { SILICA, } \\
\text { DIS - } \\
\text { SOLVED } \\
\text { (MG/L } \\
\text { AS } \\
\text { SIO2) }\end{array}$ & $\begin{array}{c}\text { NITRO- } \\
\text { GEN, } \\
\text { AMMONIA } \\
\text { DIS- } \\
\text { SOLVED } \\
\text { (MG/L } \\
\text { AS N) }\end{array}$ & $\begin{array}{l}\text { NITRO- } \\
\text { GEN, } \\
\text { NITRITE } \\
\text { DIS- } \\
\text { SOLVED } \\
\text { (MG/L } \\
\text { AS N) }\end{array}$ & $\begin{array}{c}\text { NITRO- } \\
\text { GEN, } \\
\text { NITRITE } \\
\text { DIS- } \\
\text { SOLVED } \\
\text { (MG/L } \\
\text { AS NO2) }\end{array}$ & $\begin{array}{l}\text { NITRO - } \\
\text { GEN, AM- } \\
\text { MONIA + } \\
\text { ORGANIC } \\
\text { DIS. } \\
\text { (MG/L } \\
\text { AS N) }\end{array}$ & $\begin{array}{c}\text { NITRO- } \\
\text { GEN, } \\
\text { NO2+NO3 } \\
\text { DIS - } \\
\text { SOLVED } \\
\text { (MG/L } \\
\text { AS N) }\end{array}$ & $\begin{array}{c}\text { PHOS - } \\
\text { PHATE, } \\
\text { ORTHO, } \\
\text { DIS - } \\
\text { SOLVED } \\
\text { (MG/L } \\
\text { AS PO4) }\end{array}$ & $\begin{array}{c}\text { PHOS - } \\
\text { PHORUS } \\
\text { DIS- } \\
\text { SOLVED } \\
\text { (MG/L } \\
\text { AS P) }\end{array}$ & $\begin{array}{l}\text { PHOS - } \\
\text { PHORUS } \\
\text { ORTHO, } \\
\text { DIS- } \\
\text { SOLVED } \\
\text { (MG/L } \\
\text { AS P) }\end{array}$ \\
\hline $\begin{array}{c}\text { JAN } 1976 \\
21 \ldots \\
\text { AUG } 1996 \\
08 \ldots\end{array}$ & $\begin{array}{l}0.90 \\
0.90\end{array}$ & 9.6 & 0.030 & $<0.010$ & - & $<0.20$ & 0.700 & 0.03 & $<0.010$ & 0.010 \\
\hline DATE & $\begin{array}{l}\text { SOLIDS, } \\
\text { RESIDUE } \\
\text { AT } 180 \\
\text { DEG. C } \\
\text { DIS- } \\
\text { SOLVED } \\
\text { (MG/L) }\end{array}$ & $\begin{array}{c}\text { SOLIDS, } \\
\text { SUM OF } \\
\text { CONSTI - } \\
\text { TUENTS, } \\
\text { DIS- } \\
\text { SOLVED } \\
\text { (MG/L) }\end{array}$ & $\begin{array}{c}\text { SOLIDS, } \\
\text { DIS- } \\
\text { SOLVED } \\
\text { (TONS } \\
\text { PER } \\
\text { AC-FT) }\end{array}$ & $\begin{array}{l}\text { ALUM- } \\
\text { INUM, } \\
\text { DIS- } \\
\text { SOLVED } \\
\text { (UG/L } \\
\text { AS AL) }\end{array}$ & $\begin{array}{l}\text { ANTI- } \\
\text { MONY, } \\
\text { DIS- } \\
\text { SOLVED } \\
\text { (UG/I } \\
\text { AS SB) }\end{array}$ & $\begin{array}{c}\text { ARSENIC } \\
\text { DIS - } \\
\text { SOLVED } \\
\text { (UG/L } \\
\text { AS AS) }\end{array}$ & $\begin{array}{l}\text { BARIUM, } \\
\text { DIS- } \\
\text { SOLVED } \\
\text { (UG/L } \\
\text { AS BA) }\end{array}$ & $\begin{array}{l}\text { BERYL- } \\
\text { LIUM, } \\
\text { DIS- } \\
\text { SOLVED } \\
\text { (UG/L } \\
\text { AS BE) }\end{array}$ & $\begin{array}{c}\text { BROMIDE } \\
\text { DIS- } \\
\text { SOLVED } \\
\text { (MG/L } \\
\text { AS BR) }\end{array}$ & $\begin{array}{c}\text { CADMIUM } \\
\text { DIS- } \\
\text { SOLVED } \\
\text { (UG/L } \\
\text { AS CD) }\end{array}$ \\
\hline $\begin{array}{c}\text { JAN } 1976 \\
21 \ldots \\
\text { AUG } 1996 \\
08 \ldots\end{array}$ & 367 & 356 & 0.48 & $\cdots$ & $<1$ & $<1$ & $<100$ & $<1$ & 0.040 & $<1.0$ \\
\hline DATE & $\begin{array}{l}\text { CHRO- } \\
\text { MIUM, } \\
\text { DIS- } \\
\text { SOLVED } \\
\text { (UG/L } \\
\text { AS CR) }\end{array}$ & $\begin{array}{l}\text { COBALT, } \\
\text { DIS- } \\
\text { SOLVED } \\
\text { (UG/L } \\
\text { AS CO) }\end{array}$ & $\begin{array}{l}\text { COPPER, } \\
\text { DIS- } \\
\text { SOLVED } \\
\text { (UG/L } \\
\text { AS CU) }\end{array}$ & $\begin{array}{l}\text { IRON, } \\
\text { DIS- } \\
\text { SOLVED } \\
\text { (UG/L } \\
\text { AS FE) }\end{array}$ & $\begin{array}{l}\text { LEAD, } \\
\text { DIS- } \\
\text { SOLVED } \\
\text { (UG/L } \\
\text { AS PB) }\end{array}$ & $\begin{array}{l}\text { MANGA - } \\
\text { NESE, } \\
\text { DIS- } \\
\text { SOLVED } \\
\text { (UG/L } \\
\text { AS MN) }\end{array}$ & $\begin{array}{c}\text { MERCURY } \\
\text { DIS - } \\
\text { SOLVED } \\
\text { (UG/L } \\
\text { AS HG) }\end{array}$ & $\begin{array}{l}\text { MOLYB- } \\
\text { DENUM, } \\
\text { DIS- } \\
\text { SOLVED } \\
\text { (UG/L } \\
\text { AS MO) }\end{array}$ & $\begin{array}{l}\text { NICKEL, } \\
\text { DIS- } \\
\text { SOLVED } \\
\text { (UG/L } \\
\text { AS NI) }\end{array}$ & $\begin{array}{c}\text { SILVER, } \\
\text { DIS - } \\
\text { SOLVED } \\
\text { (UG/L } \\
\text { AS AG) }\end{array}$ \\
\hline
\end{tabular}

JAN 1976

AUG $19 \dot{9} 6$

$08 \ldots$.

AS CR) AS CO)

AS CU)

AS FE)

AS PB)

AS MN)

AS NI) (UG/L

\begin{tabular}{|c|c|c|c|c|c|c|c|c|c|}
\hline-- & $\cdots$ & 14 & 60 & 9 & $<10$ & $<0.5$ & 2 & -- & -- \\
\hline 5 & $<1$ & 2 & $<3$ & $<1$ & $<1$ & $\cdots$ & 2 & 2 & $<1.0$ \\
\hline $\begin{array}{l}\text { LE- } \\
\text { UM, } \\
\text { IS- } \\
\text { LVED } \\
\text { JG/L } \\
\text { SE) }\end{array}$ & $\begin{array}{l}\text { ZINC, } \\
\text { DIS- } \\
\text { SOLVED } \\
\text { (UG/L } \\
\text { AS ZN) }\end{array}$ & $\begin{array}{c}\text { URANIUM } \\
\text { NATURAL } \\
\text { DIS - } \\
\text { SOLVED } \\
\text { (UG/L } \\
\text { AS U) }\end{array}$ & $\begin{array}{c}\text { RADIUM } \\
226, \\
\text { DIS- } \\
\text { SOLVED, } \\
\text { RADON } \\
\text { METHOD } \\
\text { (PCI/L) }\end{array}$ & $\begin{array}{l}\text { GROSS } \\
\text { ALPHA, } \\
\text { DIS - } \\
\text { SOLVED } \\
\text { (UG/L } \\
\text { AS } \\
\text { U-NAT) }\end{array}$ & $\begin{array}{l}\text { GROSS } \\
\text { BETA, } \\
\text { DIS - } \\
\text { SOLVED } \\
\text { (PCI/L } \\
\text { AS SR/ } \\
\text { Y-90) }\end{array}$ & $\begin{array}{c}\text { GROSS } \\
\text { BETA, } \\
\text { DIS- } \\
\text { SOLVED } \\
\text { (PCI/L } \\
\text { AS } \\
\text { CS-137) }\end{array}$ & $\begin{array}{l}\text { POTAS- } \\
\text { SIUM } 40 \\
\text { TOTAL } \\
(\mathrm{PCI} / \mathrm{L})\end{array}$ & $\begin{array}{l}\text { TRITIUM } \\
\text { TOTAL } \\
\text { (PCI/L) }\end{array}$ & $\begin{array}{c}\text { TRITIUM } \\
2 \text { SIGMA } \\
\text { WATER, } \\
\text { WHOLE, } \\
\text { TOTAL } \\
\text { (PCI/L) }\end{array}$ \\
\hline
\end{tabular}

JAN 1976
$21 \ddot{1} 966$

DATE

AS SE)

AS ZN)

12

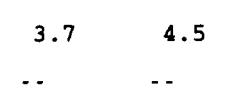

1.3

50

3.8 
WATER -QUALITY DATA

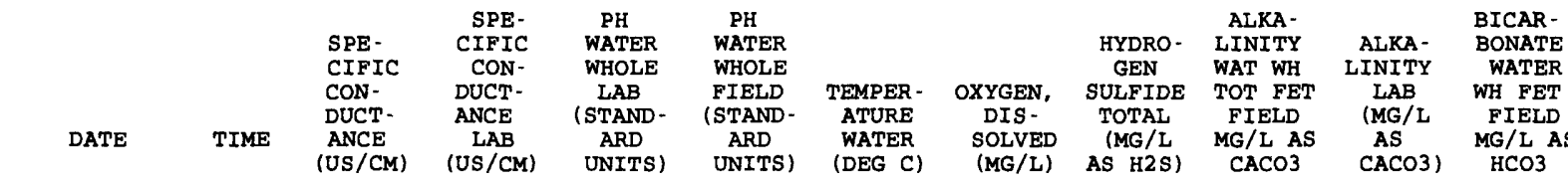

\begin{tabular}{|c|c|c|c|c|c|c|c|c|c|c|c|}
\hline AUG 19596 & 1350 & 1300 & - & $\cdots$ & . & $\cdots$ & $\cdots$ & $\cdots$ & 383 & $\cdots$ & 440 \\
\hline $21 \ldots$ & 1335 & 1342 & 1270 & 7.2 & 7.29 & 16.7 & 0.89 & 0.002 & 468 & 404 & - \\
\hline
\end{tabular}

\begin{tabular}{|c|c|c|c|c|c|c|c|c|c|c|}
\hline DATE & $\begin{array}{l}\text { HARD- } \\
\text { NESS } \\
\text { TOTAL } \\
\text { (MG/L } \\
\text { AS } \\
\text { CACO3) } \\
(00900)\end{array}$ & $\begin{array}{l}\text { HARD- } \\
\text { NESS } \\
\text { NONCARB } \\
\text { WH WAT } \\
\text { TOT FLD } \\
\text { MG/L AS } \\
\text { CACO3 } \\
(00902)\end{array}$ & $\begin{array}{l}\text { CALCIUM } \\
\text { DIS. } \\
\text { SOLVED } \\
\text { (MG/L } \\
\text { AS CA) } \\
(00915)\end{array}$ & $\begin{array}{c}\text { MAGNE- } \\
\text { SIUM, } \\
\text { DIS - } \\
\text { SOLVED } \\
\text { (MG/L } \\
\text { AS MG) } \\
(00925)\end{array}$ & $\begin{array}{l}\text { SODIUM, } \\
\text { DIS - } \\
\text { SOLVED } \\
\text { (MG/L } \\
\text { AS NA) } \\
(00930)\end{array}$ & $\begin{array}{c}\text { SODIUM } \\
\text { AD- } \\
\text { SORP- } \\
\text { TION } \\
\text { RATIO } \\
(00931)\end{array}$ & $\begin{array}{l}\text { SODIUM } \\
\text { PERCENT } \\
(00932)\end{array}$ & $\begin{array}{c}\text { POTAS - } \\
\text { SIUM, } \\
\text { DIS- } \\
\text { SOLVED } \\
\text { (MG/L } \\
\text { AS K) } \\
(00935)\end{array}$ & $\begin{array}{l}\text { CHLO- } \\
\text { RIDE, } \\
\text { DIS - } \\
\text { SOLVED } \\
\text { (MG/L } \\
\text { AS CL) } \\
(00940)\end{array}$ & $\begin{array}{l}\text { SULFATE } \\
\text { DIS - } \\
\text { SOLVED } \\
\text { (MG/L } \\
\text { AS SO4) } \\
(00945)\end{array}$ \\
\hline
\end{tabular}

FEB 1976
A 1956
21. 1996

$21 \ldots$

$$
\begin{array}{ccc}
630 & 250 & 100 \\
640 & \cdots & 100 \\
& & \\
& & \\
& & \\
\text { FLUO- } & \text { SILICA, } \\
\text { RIDE, } & \text { DIS- } \\
\text { DIS- } & \text { SOLVED } \\
\text { SOLVED } & \text { (MG/L } \\
\text { (MG/L } & \text { AS } & \text { SOL } \\
\text { AS F) } & \text { SIO2) } & \text { S } \\
& &
\end{array}
$$

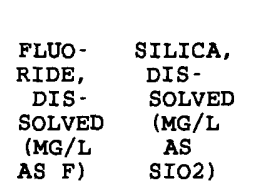

$$
100
$$

$$
93
$$$$
47
$$$$
94
$$$$
45
$$

$\begin{array}{ll}0.8 & 14 \\ 0.8 & 13\end{array}$

$$
\begin{aligned}
& 3.3 \\
& 2.5
\end{aligned}
$$$$
8.2 \quad 330
$$$$
2.3 \quad 350
$$

FEB 1976 AUG 19596

21...

(1)

DATE

FEB 1976

$0519 \dot{6}$

AUG 1996

FEB 1976

$05 \ldots$

AUG $19 \dot{9} 6$

$21 \ldots$

FEB 1976

$05 \ldots$

AUG 1996

$21 \ldots$

NITRO- NITRO-

GEN, GEN, GEN, AM - GEN,

AMMONIA NITRITE NITRITE MONIA + NO2+NO3

ATS

DIS- DIS- ORGANIC

ORGANIC DIS.

SOLVED SOLVED SOLVED DIS.

(MG/L

(MG/L

(MG/L

DIS -

(MG/L

AS N)

PHOS -

PHATE PHOS- PHORU

ORTHO, PHORUS ORTHO,

DIS - DIS - DIS.

SOLVED SOLVED SOLVED

(MG/L (MG/L (MG/L
$\begin{array}{lll}0.0 & \cdots & 0.150 \\ \cdots & <0.20 & 0.050\end{array}$
0.03
$0.03<0.010$
0.010
$0.120<0.010$
0.050
$\begin{array}{ll}2.4 & 19 \\ 2.3 & 21\end{array}$

SOLIDS, ALUM- ANTI -

SOLIDS, SOLIDS

RESIDUE SUM OF

180

DEG 18

DEG. C TUENTS

DIS - DIS -

SOLVED SOLVED

DIS-
SOLVED
(TONS

INUM,

DIS -

SOLVED SOLVED

(UG/L (UG/L

$\begin{array}{cl}\text { PER } & \text { (UG/L } \\ \text { AC-FT) AS } & \end{array}$

AS SB)

$\begin{array}{cc}\text { ARSENIC } & \text { BARIUM, } \\ \text { DIS- } & \text { DIS- } \\ \text { SOLVED } & \text { SOLVED } \\ \text { (UG/L } & \text { (UG/L } \\ \text { AS AS) } & \text { AS BA) }\end{array}$

BERYL -

LIUM, BROMIDE CADMIUM

DIS - DIS - DIS -

SOLVED SOLVED SOLVED

(UG/L (MG/L (UG/L

AS BE) AS BR) AS CD)

$\begin{array}{rrrrrrrrrr}\cdots & 836 & 1.14 & \ldots & \ldots & <1 & <100 & \ldots & \ldots & <2.0 \\ 910 & 860 & 1.24 & 3 & <1 & <1 & 45 & <1 & 0.14 & <1.0\end{array}$

CHRO-
MIUM, COBALT, COPPER, IRON, LEAD, NANGA-
NESE, MERCURY

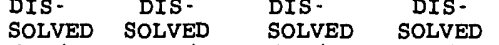

(UG/L (UG/L SOLVED

AS CR) AS CO) AS CU) AS FE)

DIS-
SOLVED

DIS.

MOLYB-

\begin{tabular}{|c|c|c|c|c|c|c|c|c|c|}
\hline$\cdots$ & $\cdots$ & 3 & $<10$ & 2 & 50 & $<0.5$ & 5 & $\cdots$ & $\cdots$ \\
\hline 8 & $<1$ & 1 & 230 & $<1$ & 45 & $\cdots$ & 5 & 4 & $<1.0$ \\
\hline $\begin{array}{l}\text { SELE- } \\
\text { NIUM, } \\
\text { DIS- } \\
\text { SOLVED } \\
\text { (UG/L } \\
\text { AS SE) }\end{array}$ & $\begin{array}{l}\text { ZINC, } \\
\text { DIS- } \\
\text { SOLVED } \\
\text { (UG/L } \\
\text { AS ZN) }\end{array}$ & $\begin{array}{c}\text { URANIUM } \\
\text { NATURAL } \\
\text { DIS- } \\
\text { SOLVED } \\
\text { (UG/L } \\
\text { AS U) }\end{array}$ & $\begin{array}{c}\text { RADIUM } \\
226, \\
\text { DIS- } \\
\text { SOLVED, } \\
\text { RADON } \\
\text { METHOD } \\
\text { (PCI/L) }\end{array}$ & $\begin{array}{c}\text { GROSS } \\
\text { ALPHA, } \\
\text { DIS - } \\
\text { SOLVED } \\
\text { (UG/L } \\
\text { AS } \\
\text { U-NAT) }\end{array}$ & $\begin{array}{l}\text { GROSS } \\
\text { BETA, } \\
\text { DIS - } \\
\text { SOLVED } \\
(\text { PCI/L } \\
\text { AS SR/ } \\
\text { Y-90) }\end{array}$ & $\begin{array}{c}\text { GROSS } \\
\text { BETA, } \\
\text { DIS- } \\
\text { SOLVED } \\
\text { (PCI/L } \\
\text { AS } \\
\text { CS-137) }\end{array}$ & $\begin{array}{l}\text { POTAS - } \\
\text { SIUM } 40 \\
\text { TOTAL } \\
\text { (PCI /L) }\end{array}$ & $\begin{array}{l}\text { TRITIUM } \\
\text { TOTAL } \\
(\text { PCI/L) }\end{array}$ & $\begin{array}{c}\text { TRITIUM } \\
2 \text { SIGMA } \\
\text { WATER, } \\
\text { WHOLE, } \\
\text { TOTAL } \\
\text { (PCI/L) }\end{array}$ \\
\hline
\end{tabular}

DENUM, NICKEL, SILVER,

DIS - DIS - DIS - DIS -

SOLVED SOLVED SOLVED SOLVED SOLVED

$\begin{array}{llllll}\text { AS PB) } & \text { AS MN) } & \text { AS HG) } & \text { AS MO) } & \text { AS NI) } & \text { AS AG) }\end{array}$

AS SE) AS ZN $\quad$ AS U) $(P C I / L) \quad$ U-NAT)

$\mathrm{Y}-90)$

- 137)

PCI/L) (PCI/L) (PCI/L)

$\begin{array}{rrrrrrrrrr}<1 & 2700 & \ldots & \ldots & 36 & 14 & 18 & 2.3 & \ldots & \ldots \\ <1 & 6 & 5.0 & \ldots & \ldots & -\ldots & \ldots & \ldots & <2.5 & 1.9\end{array}$


WATER-QUALITY DATA



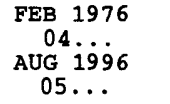

0900

1300

$\begin{array}{cc}270 & \cdots \\ 305 & 305\end{array}$

$\begin{array}{ccc}\cdots & \cdots & \cdots \\ 15.1 & 7.02 & \ldots\end{array}$

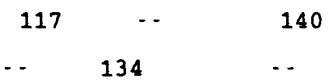

FEB 1976

AUG 1996

$05 . .$.

$\begin{array}{lll} & \text { HARD - } \\ \text { HARD- } & \text { NESS } & \\ \text { NESS } & \text { NONCARB } & \text { CALCIUM } \\ \text { TOTAL } & \text { WH WAT } & \text { DIS- } \\ \text { (MG/L } & \text { TOT FLD } & \text { SOLVED } \\ \text { AS } & \text { MG/L AS } & \text { (MG/L } \\ \text { CACO3) } & \text { CACO3 } & \text { AS CA) }\end{array}$

MAGNE -

SIUM, SODIUM,

DIS -

SOLVED

$\begin{array}{ll}\text { (MG/L } & \text { (MG/L } \\ \text { AS MG) AS NA) }\end{array}$

SODIUM
AD-
SORP-
TION
RATIO

SODIUM
PERCENT

SIUM, RIDE, SULFATE DIS - DIS - DIS -

SOLVED SOLVED SOLVED

(MG/L (MG/L (MG/L

140

$\begin{array}{rr}24 & 45 \\ \ldots & 39\end{array}$

$\begin{array}{cc}7.0 & 7.7 \\ 7.5 & 12\end{array}$

0.3

11

0.70

3.620

130

39

0.5

17

0.60

3.216

$\begin{array}{ll} & \\ \text { FLUO- } & \text { SILICA, } \\ \text { RIDE, } & \text { DIS- } \\ \text { DIS- } & \text { SOLVED } \\ \text { SOLVED } & \text { (MG/L } \\ \text { (MG } / L & \text { AS } \\ \text { AS F) } & \text { SIO2) }\end{array}$

NITRO- NITRO- NITRO-

NITRO- NITRO-

PHOS -
PHATE, PHOS - PHORUS

PHATE, PHOS- PHORUS

ORTHO, PHORUS ORTHO,

DIS - DIS - DIS -

SOLVED SOLVED SOLVED

(MG/L (MG/L (MG/L

DATE

SOLVED

SOLVED SOLVED DIS.

AS N) AS NO2) AS N)

(MG/L

AS PO4)

(MG/L (MG/L

FEB 1976

$04 \ldots$

AUG $19 \dot{9} 6$

$$
0.40 \quad 13
$$

$-<<0.010$

0.0

0.740

0.0

$\ldots \quad<0.010$

$0.50 \quad 15$

$0.020<0.010$

$\therefore<0.20$

0.450

$0.12<0.010$

0.040

SOLIDS, SOLIDS,

$\begin{array}{lllllll}\text { SOLIDS, } & \text { SOLIDS, } & & & & \\ \text { RESIDUE } & \text { SUM OF } & \text { SOLIDS, } & \text { ALUM- } & \text { ANTI- } & & \\ \text { AT } 180 & \text { CONSTI- } & \text { DIS- } & \text { INUM, } & \text { MONY, } & \text { ARSENIC } & \text { BARIUM, } \\ \text { DEG. C } & \text { TUENTS, } & \text { SOLVED } & \text { DIS- } & \text { DIS- } & \text { DIS- } & \text { DIS- } \\ \text { DIS- } & \text { DIS- } & \text { (TONS } & \text { SOLVED } & \text { SOLVED } & \text { SOLVED } & \text { SOLVED } \\ \text { SOLVED } & \text { SOLVED } & \text { PER } & \text { (UG/L } & \text { (UG/L } & \text { (UG/L } & \text { (UG/L } \\ \text { (MG/L) } & \text { (MG/L) } & \text { AC-FT) } & \text { AS AL) } & \text { AS SB) } & \text { AS AS) } & \text { AS BA) }\end{array}$

BERYL -

LIUM, BROMIDE CADMIUM

$\begin{array}{lcc}\text { LIUM, } & \text { BROMIDE } & \text { CADMIUM } \\ \text { DIS- } & \text { DIS- } & \text { DIS- }\end{array}$

SOLVED SOLVED SOLVED

(UG/L (MG/L (UG/L

DATE

(MG/L) (MG/L)

AC- FT)

AS AL)

AS BE)

AS BR) AS CD)

FEB 1976

04 igi

$05 \ldots$

$\begin{array}{ll}\cdots & 171 \\ 175 & 176\end{array}$

0.23
0.24

$\begin{array}{ll}\cdots & \\ 4 & <1\end{array}$

$\begin{array}{rr}<1 & <100 \\ <1 & 73\end{array}$

$<$

0.050

$<2.0$

$<1.0$

MIUM, COBALT, COP

SOLVED SOLVED SOLVED

(UG/I (UG/L

AS CR) AS CO) AS CU)

$\begin{array}{cc}\text { IRON, } & \text { LEAD, } \\ \text { DIS- } & \text { DIS- } \\ \text { SOLVED } & \text { SOLVED } \\ \text { (UG/L } & \text { (UG/L } \\ \text { AS FE) } & \text { AS PB) }\end{array}$

MANGA -

NESE, MERCURY

MOLYB -

DENUM, NICKEL, SILVER,

$\begin{array}{ccclc}\text { DIS- } & \text { DIS- } & \text { DIS- } & \text { DIS- } & \text { DIS - } \\ \text { SOLVED } & \text { SOLVED } & \text { SOLVED } & \text { SOLVED } & \text { SOLVED }\end{array}$

SOLVED SOLVED

(UG/L (UG/I

(UG/L (UG/L (UG/L

AS MO) AS NI) AS AG)

FEB 1976

04 . 196

$05 .$. .

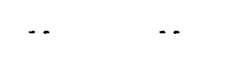

$33<10$

2
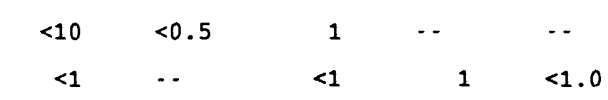

$\begin{array}{ccccc} & & & \text { RADIUM } & \text { GROSS } \\ \text { SELE- } & & \text { URANIUM } & 226, & \text { ALPHA, } \\ \text { NIUM, } & \text { ZINC, } & \text { NATURAL } & \text { DIS- } & \text { DIS- } \\ \text { DIS- } & \text { DIS- } & \text { DIS- } & \text { SOLVED, } & \text { SOLVED } \\ \text { SOLVED } & \text { SOLVED } & \text { SOLVED } & \text { RADON } & \text { (UG/L } \\ \text { (UG/L } & \text { (UG/L } & \text { (UG/L } & \text { METHOD } & \text { AS } \\ \text { AS SE) } & \text { AS ZN) } & \text { AS U) } & \text { (PCI/L) } & \text { U-NAT) }\end{array}$

GROSS
BETA,
DIS-
SOLVED
(PCI/L
AS SR/
Y-90)

GROSS

BETA,

BETA,
DIS-
SOLVED POTAS-
2 SIGMA

(PCI/L SIUM 40 TRITIUM WATER,

AS TOTAL TOTAL TOTAL,

DATE

$\begin{array}{rrrrc}<1 & 210 & \ldots & \ldots & <3.1 \\ <1 & 11 & 2.0 & \ldots & \ldots\end{array}$

EB 1976

04 .

$05 \ldots$...

$\begin{array}{lll}<1 & 11 & 2.0\end{array}$ 
WATER-QUALITY DATA

\begin{tabular}{|c|c|c|c|c|c|c|c|c|c|c|c|}
\hline DATE & TIME & $\begin{array}{l}\text { SPE- } \\
\text { CIFIC } \\
\text { CON- } \\
\text { DUCT- } \\
\text { ANCE } \\
\text { (US/CM) }\end{array}$ & $\begin{array}{c}\text { SPE- } \\
\text { CIFIC } \\
\text { CON- } \\
\text { DUCT- } \\
\text { ANCE } \\
\text { LAB } \\
\text { (US/CM) }\end{array}$ & $\begin{array}{c}\text { PH } \\
\text { WATER } \\
\text { WHOLE } \\
\text { LAB } \\
\text { (STAND- } \\
\text { ARD } \\
\text { UNITS) }\end{array}$ & $\begin{array}{c}\text { PH } \\
\text { WATER } \\
\text { WHOLE } \\
\text { FIELD } \\
\text { (STAND- } \\
\text { ARD } \\
\text { UNITS) }\end{array}$ & $\begin{array}{c}\text { TEMPER - } \\
\text { ATURE } \\
\text { WATER } \\
\text { (DEG C) }\end{array}$ & $\begin{array}{c}\text { OXYGEN, } \\
\text { DIS - } \\
\text { SOLVED } \\
\text { (MG/L) }\end{array}$ & $\begin{array}{l}\text { HYDRO- } \\
\text { GEN } \\
\text { SULFIDE } \\
\text { TOTAL } \\
\text { (MG/L } \\
\text { AS H2S) }\end{array}$ & $\begin{array}{l}\text { ALKA- } \\
\text { LINITY } \\
\text { WAT WH } \\
\text { TOT FET } \\
\text { FIELD } \\
\text { MG/L AS } \\
\text { CACO3 }\end{array}$ & $\begin{array}{c}\text { ALKA - } \\
\text { LINITY } \\
\text { LAB } \\
\text { (MG/L } \\
\text { AS } \\
\text { CACO3) }\end{array}$ & $\begin{array}{c}\text { BICAR- } \\
\text { BONATE } \\
\text { WATER } \\
\text { WH FET } \\
\text { FIELD } \\
\text { MG/L AS } \\
\text { HCO3 }\end{array}$ \\
\hline
\end{tabular}

FEB 1976

AUG $119 \dot{9}$

1250

375

-

-

13.0

$\cdots$
1.64

$\cdots$

170

$14 \ldots$

1320

499

493

$7.3 \quad 7.66$

12.1

1.64

$\begin{array}{ccc}\text { MAGNE- } & & \text { SODIUM } \\ \text { SIUM, } & \text { SODIUM, } & \text { AD- } \\ \text { DIS- } & \text { DIS- } & \text { SORP- } \\ \text { SOLVED } & \text { SOLVED } & \text { TION } \\ \text { (MG/L } & \text { (MG/L } & \text { RATIO }\end{array}$

AS MG) AS NA)
SODIUM

PERCENT

$$
\begin{array}{clc}
\text { POTAS - } & \text { CHLO- } & \\
\text { SIUM, } & \text { RIDE, } & \text { SULFATE } \\
\text { DIS - } & \text { DIS - } & \text { DIS - } \\
\text { SOLVED } & \text { SOLVED } & \text { SOLVED } \\
\text { (MG/L } & \text { (MG/L } & \text { (MG/L }
\end{array}
$$

FEB 1976

AUG 11996

$14 \ldots$

$\begin{array}{llll}170 & \cdots & 50 & 11 \\ 210 & \ldots & 61 & 14\end{array}$

8.9

0.3

10

5.8

$3.6 \quad 45$

8.0

0.2

$5.5 \quad 55$

18

\section{DATE}

FEB 1976 AUG $119 \dot{9} 6$

14 ...

FEB 1976

$11 \ldots 96$

AUG 1996
$14 \ldots$

FEB 1976

AUG 11996

$14 \ldots$

FEB 1976

$11 \ldots$

AUG 1996

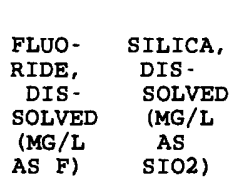

$\begin{array}{ccc}\text { NITRO- } & \text { NITRO- } & \text { NITRO- } \\ \text { GEN, } & \text { GEN, } & \text { GEN, }\end{array}$

GEN,
AMMONIA
DIS-
SOLVED
(MG/L

AS N)

$\begin{array}{ll}1.3 & 9.3 \\ 0.90 & 11\end{array}$

.. $\quad<0.010$

0.020

0.010

0.0

0.03

$<0$

2.10

2.20

SOLIDS, SOLIDS,

RESIDUE SUM OF

AT 180 CONSTIDEG. C TUENTS $\begin{array}{cc}\text { DIS- } & \text { DIS - } \\ \text { SOLVED } & \text { SOLVED } \\ (M G / L) & (M G / L)\end{array}$

SOLIDS, ALUM- ANTI -

DIS -
SOLVED
(TONS

(TONS

PER

ALUM -

ANUM,

INUM,
DIS-
SOLVED

MONY, ARSENIC BARIUM,

DIS - DIS - DIS-

$\begin{array}{llll}\text { SOLVED } & \text { SOLVED } & \text { SOLVED } & \text { SOLVED } \\ \text { (UG } / L & \text { (UG/L } & \text { (UG/L } & \text { (UG/L }\end{array}$

AS AL) AS SB)

AS AS) AS BA

- 229

0.31

302

264

0.41

$\begin{array}{ll}\cdots & \cdots \\ 3 & <1\end{array}$

1
$<1$

$<100$

4

CHRO -

MIUM, COBALT, COPPER,

DIS -

$\begin{array}{lll} & \text { DIS - } & \text { DIS - } \\ \text { SOLVED } & \text { SOLVED } & \text { SOLVED }\end{array}$

(UG/L (UG/L (UG/L

AS $\mathrm{CR}$ ) AS $\mathrm{CO}$ ) AS $\mathrm{CU}$ )
IRON,
DIS-
SOLVED
(UG/L
AS FE)

$\begin{array}{llc} & \text { MANGA- } \\ \text { LEAD, } & \text { NESE, } & \text { MERCURY } \\ \text { DIS- } & \text { DIS- } & \text { DIS- } \\ \text { SOLVED } & \text { SOLVED } & \text { SOLVED } \\ \text { (UG/L } & \text { (UG/L } & \text { (UG/L } \\ \text { AS PB) } & \text { AS MN) } & \text { AS HG) }\end{array}$

MOLYB -

DENUM, NICKEL, SILVER, DIS - DIS - DIS SOLVED SOLVED SOLVED (UG/L (UG/L (UG/L

AS MO) AS NI) AS AG)

$\begin{array}{lcc}\text { BERYL- } & \\ \text { LIUM, } & \text { BROMIDE } & \text { CADMIUM } \\ \text { DIS- } & \text { DIS- } & \text { DIS- } \\ \text { SOLVED } & \text { SOLVED } & \text { SOLVED } \\ \text { (UG/L } & \text { (MG/L } & \text { (UG/L } \\ \text { AS BE) } & \text { AS BR) } & \text { AS CD) }\end{array}$

$\begin{array}{ccc}\cdots & \ldots & <2.0 \\ <1 & 0.080 & <1.0\end{array}$


WATER-QUALITY DATA

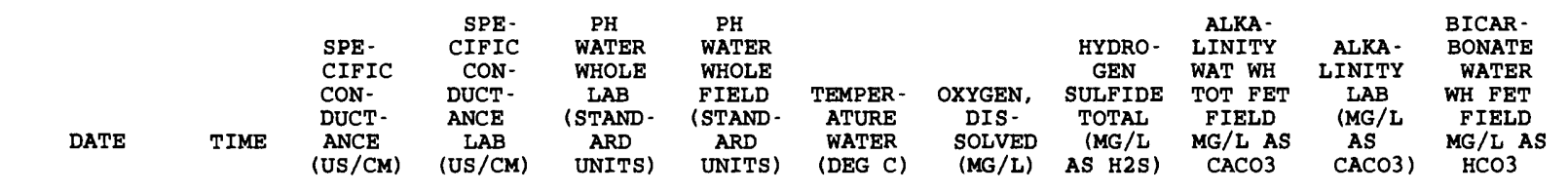

FEB 1976
$11 \ldots 96$
AUG 1996
$08 \ldots$

$\begin{array}{rr}1800 & -\cdots \\ 1436 & 1450\end{array}$

$\begin{array}{cr}\ldots & \ldots \\ 8.4 & 8.72\end{array}$ $\begin{array}{cc}26.0 & \cdots \\ 20.5 & 0.1\end{array}$

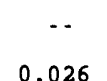

1260

$\begin{array}{lr}1030 & \cdots \\ 800 & 762\end{array}$

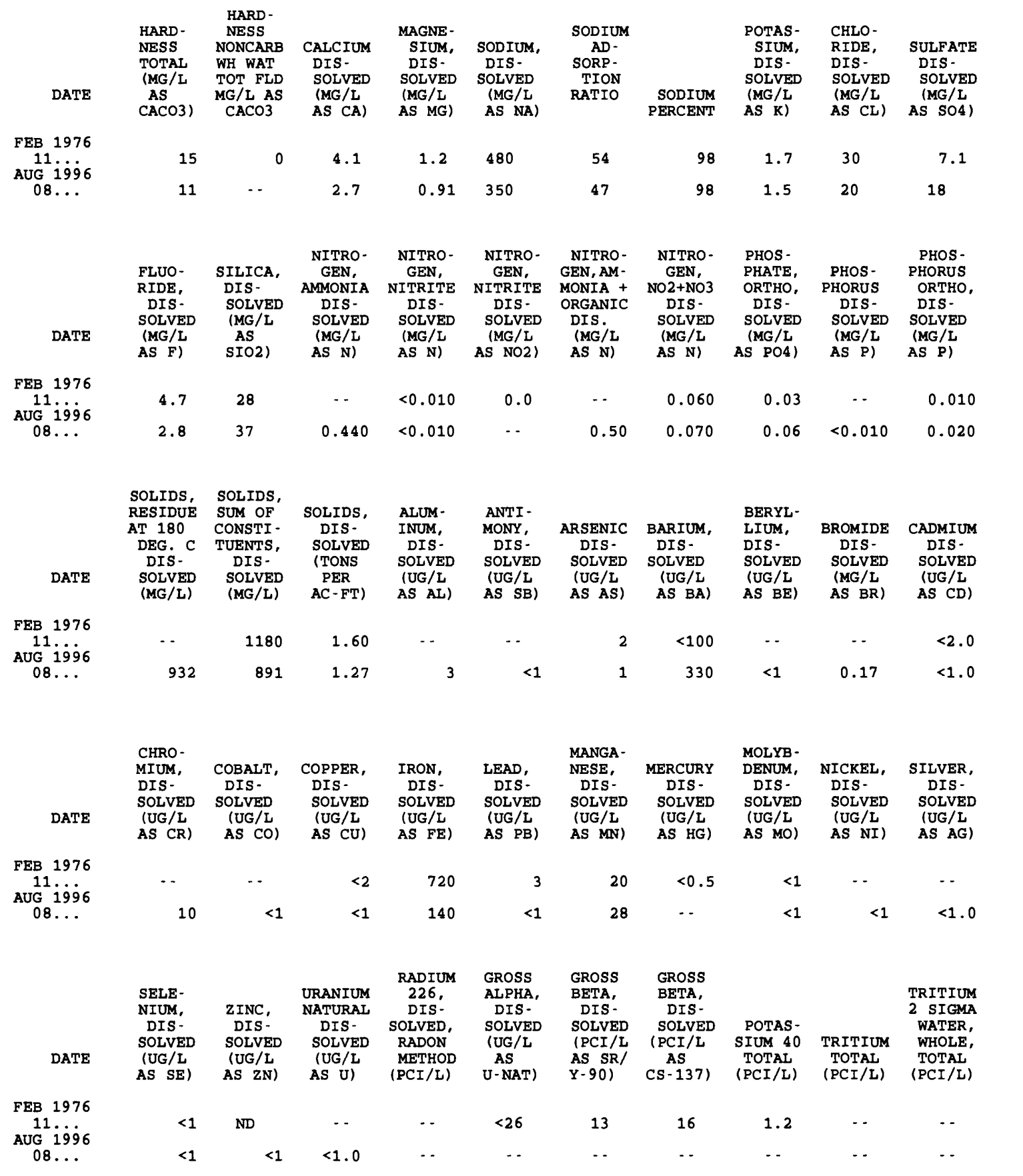


WATER-QUALITY DATA

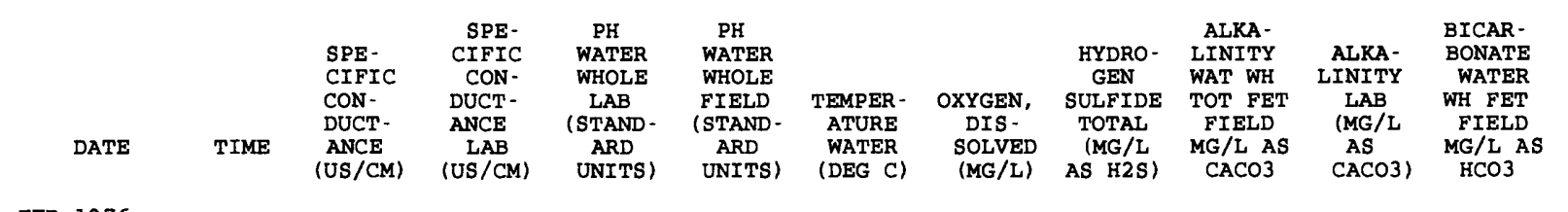

$\begin{array}{ccccccccccccc}\text { FEB } 1976 & & & & & & & \\ 12 & 1250 & 569 & \ldots & \ldots & \ldots & 9.0 & \ldots & \ldots & \ldots \\ \text { AUG } 1996 & 12115 & 401 & 395 & 6.8 & 6.78 & 12.8 & 4.44 & \ldots & 100 & 115 & \ldots\end{array}$

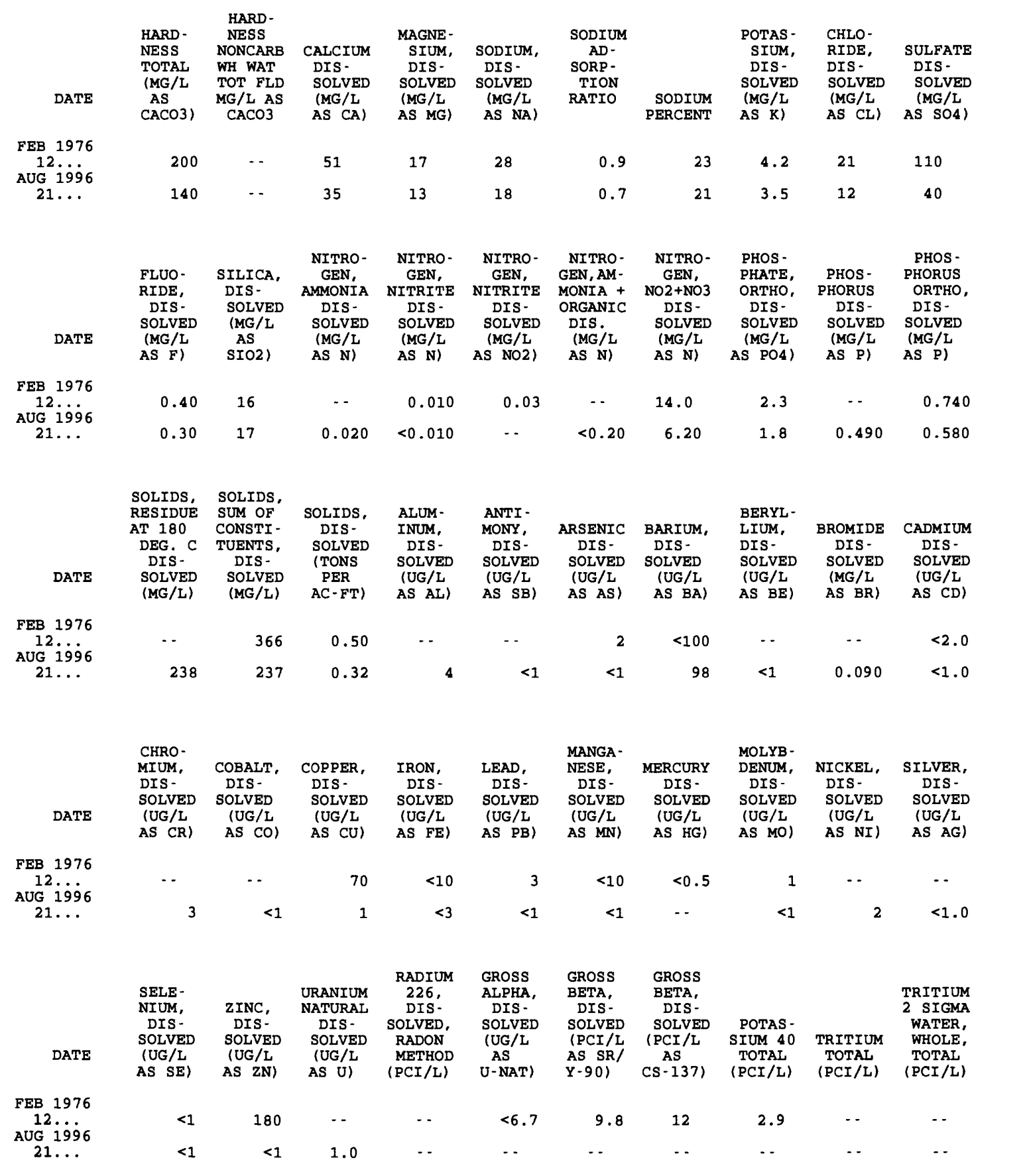


WATER-QUALITY DATA

\begin{tabular}{|c|c|c|c|c|c|c|c|c|c|c|c|}
\hline DATE & TIME & $\begin{array}{l}\text { SPE- } \\
\text { CIFIC } \\
\text { CON- } \\
\text { DUCT- } \\
\text { ANCE } \\
\text { (US/CM) }\end{array}$ & $\begin{array}{c}\text { SPE- } \\
\text { CIFIC } \\
\text { CON- } \\
\text { DUCT- } \\
\text { ANCE } \\
\text { LAB } \\
\text { (US/CM) }\end{array}$ & $\begin{array}{c}\text { PH } \\
\text { WATER } \\
\text { WHOLE } \\
\text { LAB } \\
\text { (STAND - } \\
\text { ARD } \\
\text { UNITS) }\end{array}$ & $\begin{array}{c}\text { PH } \\
\text { WATER } \\
\text { WHOLE } \\
\text { FIELD } \\
\text { (STAND- } \\
\text { ARD } \\
\text { UNITS) }\end{array}$ & $\begin{array}{c}\text { TEMPER - } \\
\text { ATURE } \\
\text { WATER } \\
\text { (DEG C) }\end{array}$ & $\begin{array}{c}\text { OXYGEN, } \\
\text { DIS - } \\
\text { SOLVED } \\
\text { (MG/L) }\end{array}$ & $\begin{array}{l}\text { HYDRO- } \\
\text { GEN } \\
\text { SULFIDE } \\
\text { TOTAL } \\
\text { (MG/L } \\
\text { AS H2S) }\end{array}$ & $\begin{array}{l}\text { ALKA- } \\
\text { LINITY } \\
\text { WAT WH } \\
\text { TOT FET } \\
\text { FIELD } \\
\text { MG/L AS } \\
\text { CACO3 }\end{array}$ & $\begin{array}{c}\text { ALKA- } \\
\text { LINITY } \\
\text { LAB } \\
\text { (MG/L } \\
\text { AS } \\
\text { CACO3) }\end{array}$ & $\begin{array}{c}\text { BICAR- } \\
\text { BONATE } \\
\text { WATER } \\
\text { WH FET } \\
\text { FIELD } \\
\text { MG/L AS } \\
\text { HCO3 }\end{array}$ \\
\hline $\begin{array}{l}\text { MAR } 1976 \\
0220 \\
\text { SEP } 1996\end{array}$ & 1300 & 440 & $\cdots$ & $\cdots$ & - & $\cdots$ & $\cdots$ & $-\cdots$ & 226 & -- & 280 \\
\hline $03 \ldots$ & 1130 & 336 & 415 & 6.7 & 7.15 & 14.0 & 0.52 & 0.029 & 154 & 103 & -- \\
\hline
\end{tabular}




WATER-QUALITY DATA




WATER-QUALITY DATA

\begin{tabular}{|c|c|c|c|c|c|c|c|c|c|c|c|}
\hline DATE & TIME & $\begin{array}{l}\text { SPE- } \\
\text { CIFIC } \\
\text { CON- } \\
\text { DUCT- } \\
\text { ANCE } \\
\text { (US/CM) }\end{array}$ & $\begin{array}{c}\text { SPE- } \\
\text { CIFIC } \\
\text { CON- } \\
\text { DUCT - } \\
\text { ANCE } \\
\text { LAB } \\
\text { (US/CM) }\end{array}$ & $\begin{array}{c}\text { PH } \\
\text { WATER } \\
\text { WHOLE } \\
\text { LAB } \\
\text { (STAND - } \\
\text { ARD } \\
\text { UNITS) }\end{array}$ & $\begin{array}{c}\text { PH } \\
\text { WATER } \\
\text { WHOLE } \\
\text { FIELD } \\
\text { (STAND- } \\
\text { ARD } \\
\text { UNITS) }\end{array}$ & $\begin{array}{c}\text { TEMPER- } \\
\text { ATURE } \\
\text { WATER } \\
\text { (DEG C) }\end{array}$ & $\begin{array}{c}\text { OXYGEN, } \\
\text { DIS - } \\
\text { SOLVED } \\
\text { (MG/L) }\end{array}$ & $\begin{array}{c}\text { HYDRO- } \\
\text { GEN } \\
\text { SULFIDE } \\
\text { TOTAL } \\
\text { (MG/L } \\
\text { AS H2S) }\end{array}$ & $\begin{array}{l}\text { ALKA- } \\
\text { LINITY } \\
\text { WAT WH } \\
\text { TOT FET } \\
\text { FIELD } \\
\text { MG/L AS } \\
\text { CACO3 }\end{array}$ & $\begin{array}{c}\text { ALKA- } \\
\text { LINITY } \\
\text { LAB } \\
\text { (MG/L } \\
\text { AS } \\
\text { CACO3) }\end{array}$ & $\begin{array}{c}\text { BICAR- } \\
\text { BONATE } \\
\text { WATER } \\
\text { WH FET } \\
\text { FIELD } \\
\text { MG/L AS } \\
\text { HCO3 }\end{array}$ \\
\hline IAR 1976 & & & & & & & & & & & \\
\hline AUG $20 \ddot{1966}$ & 1100 & 2800 & $\cdots$ & $\cdots$ & - & $\cdots$ & $\cdots$ & $\cdots$ & $\cdots$ & $\cdots$ & 340 \\
\hline $08 \ldots$ & 0940 & 1814 & 2380 & 7.1 & 7.05 & 13.1 & 0.51 & $<0.002$ & 240 & 239 & $\cdots$ \\
\hline
\end{tabular}

$\begin{array}{lll} & \text { HARD - } & \\ \text { HARD - } & \text { NESS } & \\ \text { NESS } & \text { NONCARB } & \text { CALCIUM } \\ \text { TOTAL } & \text { WH WAT } & \text { DIS- } \\ \text { (MG/L } & \text { TOT FLD } & \text { SOLVED } \\ \text { AS } & \text { MG } / L \text { AS } & \text { (MG/L } \\ \text { CACO3) } & \text { CACO3 } & \text { AS CA })\end{array}$

$\begin{array}{ccc}\text { MAGNE- } & & \text { SODIUM } \\ \text { SIUM, } & \text { SODIUM, } & \text { AD- } \\ \text { DIS- } & \text { DIS- } & \text { SORP- } \\ \text { SOLVED } & \text { SOLVED } & \text { TION } \\ \text { (MG/L } & \text { (MG/L } & \text { RATIO } \\ \text { AS MG) } & \text { AS NA) } & \end{array}$

SODIUM
PERCENT

MAR 1976

$20 \ldots$

AUG 1996

$08 \ldots$

MAR 1976

AUG $190 \dot{9}$

08 ...

MAR 1976

$20 \ldots$

U 1996

$08 \ldots$

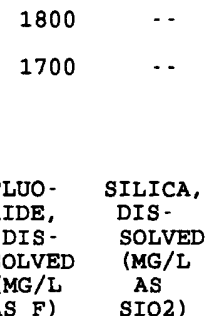

560

550

100

80

47

32

NITRO -

NITRO -

GEN, GEN,

AMMONIA NITRITE NIT

NITRITE

SOLVED

(MG/L

AS N)

DIs-

SOLVED

AS N)

SOLVED

(MG/L

AS NO2)

.. $\quad 0.010$

0.03

0.5

5

0.3

0.190

0.010

0.03

$<0.20$

0.390

0.240

$0.50 \quad 11$

\begin{abstract}
0.190
\end{abstract}
SOLIDS, SOLIDS,
RESIDUE SUM OF

RESIDUE

DEG. C TUENTS,

DIS- DIS -

$\begin{array}{ll}\text { SOLVED } & \text { SOLVED } \\ \text { (MG/L) } & \text { (MG/L) }\end{array}$

SOLIDS,
DIS -

SOLVED

(TONS

PER
AC-FT)

ALUM-
INUM,
DIS-
SOLVED

(UG/L)

$$
\begin{aligned}
& \text { ANTI- } \\
& \text { MONY, } \\
& \text { DIS- }
\end{aligned}
$$

MONY, ARSENIC BARIUM,

SOLVED

(UG/L

AS SB)

$\begin{array}{cc}\text { ARSENIC } & \text { BARIUM, } \\ \text { DIS- } & \text { DIS- } \\ \text { SOLVED } & \text { SOLVED } \\ \text { (UG/L } & \text { (UG/L }\end{array}$

AS AS) AS BA)

\begin{abstract}
$\left(-2 x^{2}\right.$
\end{abstract}

$\begin{array}{lll}\cdots & 2400 & 3.26 \\ 2400 & 2230 & 3.26\end{array}$

3

$\begin{array}{ll}- & <1 \\ <1 & <1\end{array}$
$<100$

7

CHRO-

$\begin{array}{lclllll}\text { MIUM, } & \text { COBALT, } & \text { COPPER, } & \text { IRON, } & \text { LEAD, } & \text { NESE, } & \text { MERCURY } \\ \text { DIS- } & \text { DIS- } & \text { DIS- } & \text { DIS- } & \text { DIS- } & \text { DIS- } & \text { DIS - } \\ \text { SOLVED } & \text { SOLVED } & \text { SOLVED } & \text { SOLVED } & \text { SOLVED } & \text { SOLVED } & \text { SOLVED } \\ \text { (UG/L } & \text { (UG/L } & \text { (UG/L } & \text { (UG/L } & \text { (UG/L } & \text { (UG/L } & \text { (UG/L }\end{array}$
$\begin{array}{ll}(U G / L & (U G / L \\ A S C R & A S C O)\end{array}$

AS FE)

AS PB)

AS MN) AS HG)

BERYL -

LIUM, BROMIDE CADMIUM

DIS- DIS - DIS -

SOLVED SOLVED SOLVED

(UG/L (MG/L (UG/L

AS BE) AS BR) AS CD)

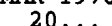

$20 \ldots$

\begin{tabular}{|c|c|c|c|c|c|c|c|c|c|}
\hline$\cdots$ & $\cdots$ & 4 & 2200 & 7 & 40 & $<0.5$ & 2 & - & $\cdots$ \\
\hline 3 & 2 & 6 & 1200 & $<1$ & 42 & $\cdots$ & 2 & 18 & $<1.0$ \\
\hline $\begin{array}{l}\text { SELE- } \\
\text { NIUM, } \\
\text { DIS - } \\
\text { SOLVED } \\
\text { (UG/L } \\
\text { AS SE) }\end{array}$ & $\begin{array}{c}\text { ZINC, } \\
\text { DIS- } \\
\text { SOLVED } \\
\text { (UG/L } \\
\text { AS ZN) }\end{array}$ & $\begin{array}{c}\text { URANIUM } \\
\text { NATURAL. } \\
\text { DIS- } \\
\text { SOLVED } \\
\text { (UG/L } \\
\text { AS U) }\end{array}$ & $\begin{array}{c}\text { RADIUM } \\
226, \\
\text { DIS- } \\
\text { SOLVED, } \\
\text { RADON } \\
\text { METHOD } \\
\text { (PCI/L) }\end{array}$ & $\begin{array}{l}\text { GROSS } \\
\text { ALPHA, } \\
\text { DIS- } \\
\text { SOLVED } \\
\text { (UG/L } \\
\text { AS } \\
\text { U-NAT) }\end{array}$ & $\begin{array}{l}\text { GROSS } \\
\text { BETA, } \\
\text { DIS- } \\
\text { SOLVED } \\
\text { (PCI/L } \\
\text { AS SR/ } \\
\text { Y- } 90 \text { ) }\end{array}$ & $\begin{array}{c}\text { GROSS } \\
\text { BETA, } \\
\text { DIS- } \\
\text { SOLVED } \\
\text { (PCI/L } \\
\text { AS } \\
\text { CS-137) }\end{array}$ & $\begin{array}{l}\text { POTAS- } \\
\text { SIUM } 40 \\
\text { TOTAL } \\
(\text { PCI/L) }\end{array}$ & $\begin{array}{l}\text { TRITIUM } \\
\text { TOTAL } \\
\text { (PCI/L) }\end{array}$ & $\begin{array}{c}\text { TRITIUM } \\
2 \text { SIGMA } \\
\text { WATER, } \\
\text { WHOLE, } \\
\text { TOTAL } \\
\text { (PCI/L) }\end{array}$ \\
\hline
\end{tabular}

AUG 1996

$08 .$.



MAR 1976

AUG $19 \dot{9} 6$

08 ...

$\begin{array}{rrrrr}<1 & 410 & \ldots & 0.12 & <35 \\ 8 & 4 & 12 & \ldots & \ldots\end{array}$

$\begin{array}{cc}10 & 12 \\ \cdots & \cdots\end{array}$
MOLYB -
DENUM, NICKEL, SILVER,
DIS- DIS - DIS -
SOLVED SOLVED SOLVED
(UG/L (UG/L (UG/L
AS MO) AS NI) AS AG)




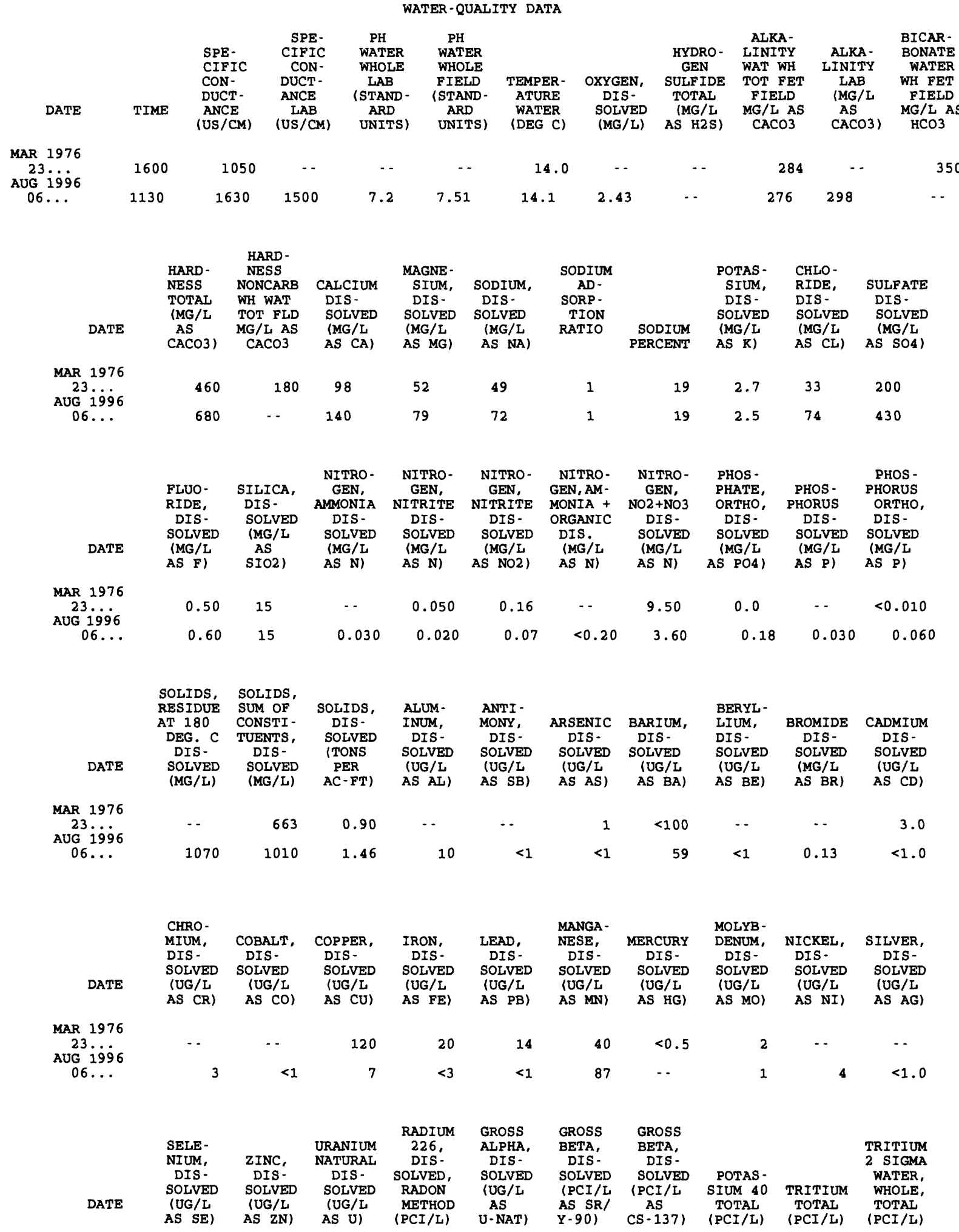

MAR 1976

$23 \ldots$

AUG 1996

$\begin{array}{rrrrr}15 & 90 & \ldots & <0.01 & 16 \\ 16 & 4 & 25 & \ldots & \ldots\end{array}$

$\begin{array}{lll}2.9 & 3.4 & 2.4 \\ \cdots & \cdots & \ldots\end{array}$ 
WATER-QUALITY DATA

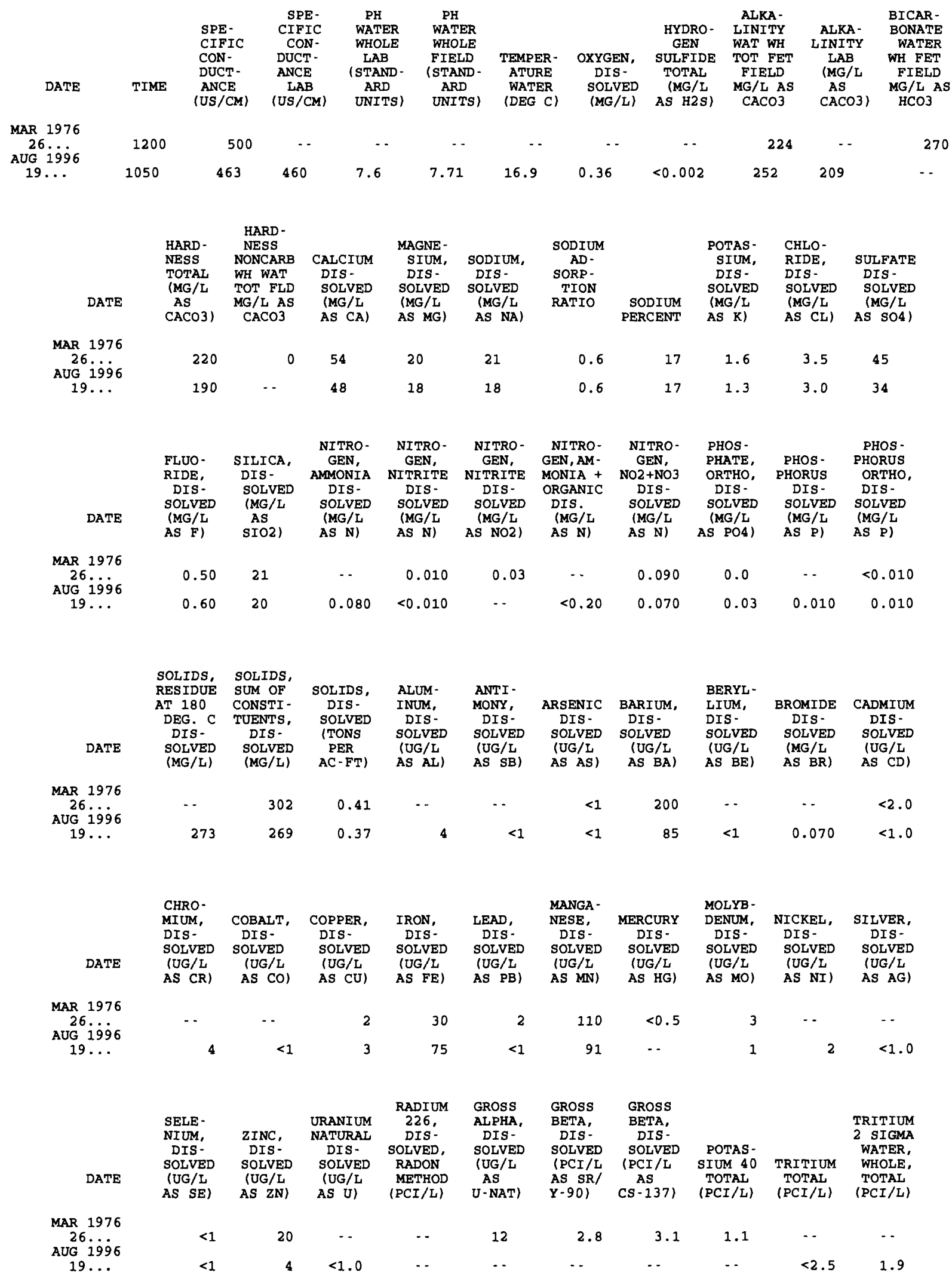


WATER-QUALITY DATA

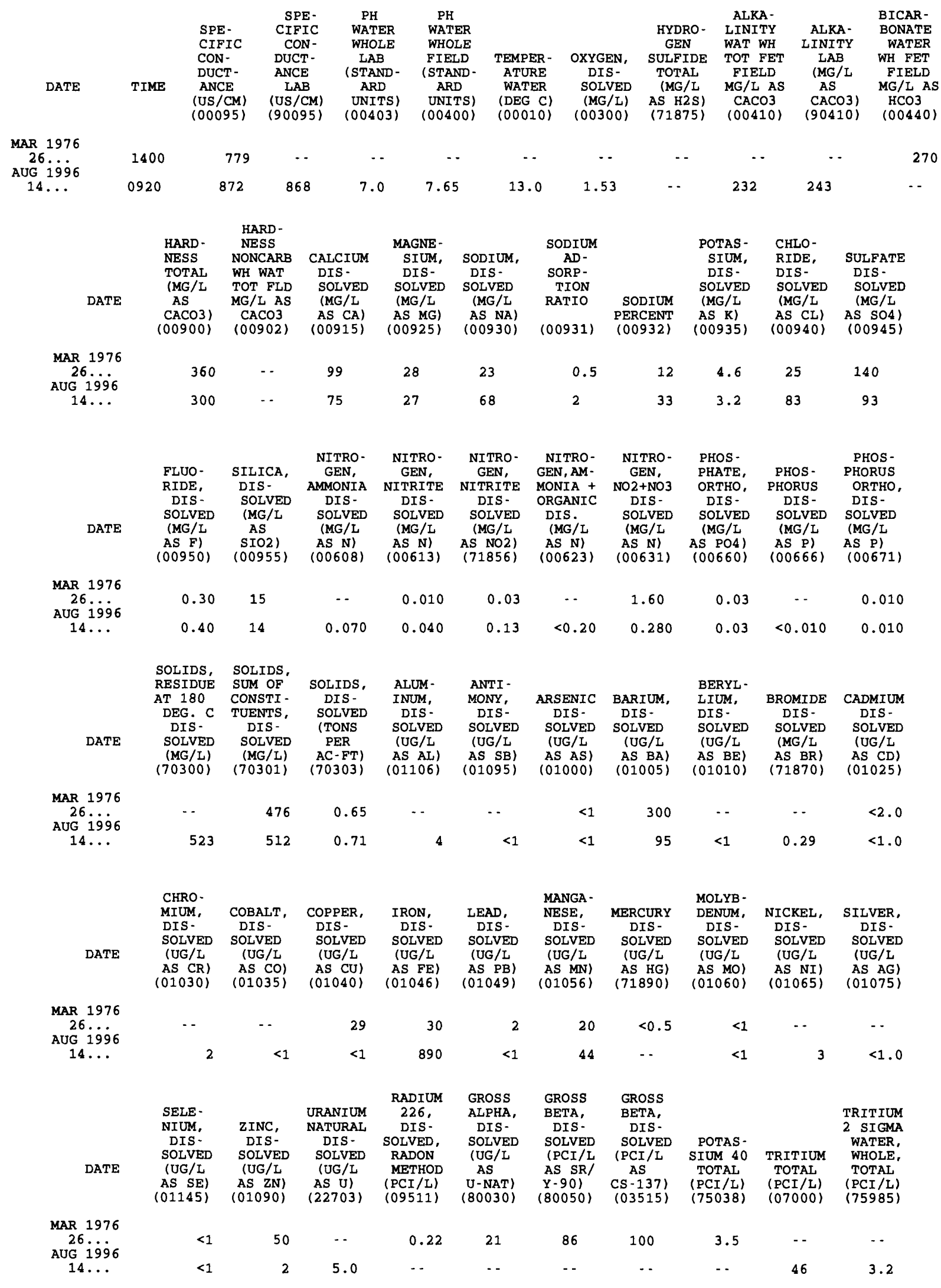


WATER-QUALITY DATA




WATER-QUALITY DATA

\begin{tabular}{|c|c|c|c|c|c|c|c|c|c|c|c|}
\hline DATE & TIME & $\begin{array}{l}\text { SPE - } \\
\text { CIFIC } \\
\text { CON- } \\
\text { DUCT- } \\
\text { ANCE } \\
\text { (US/CM) }\end{array}$ & $\begin{array}{c}\text { SPE- } \\
\text { CIFIC } \\
\text { CON- } \\
\text { DUCT- } \\
\text { ANCE } \\
\text { LAB } \\
\text { (US/CM) }\end{array}$ & $\begin{array}{c}\text { PH } \\
\text { WATER } \\
\text { WHOLE } \\
\text { LAB } \\
\text { (STAND - } \\
\text { ARD } \\
\text { UNITS) }\end{array}$ & $\begin{array}{c}\text { PH } \\
\text { WATER } \\
\text { WHOLE } \\
\text { FIELD } \\
\text { (STAND- } \\
\text { ARD } \\
\text { UNITS) }\end{array}$ & $\begin{array}{c}\text { TEMPER - } \\
\text { ATURE } \\
\text { WATER } \\
\text { (DEG C) }\end{array}$ & $\begin{array}{c}\text { OXYGEN, } \\
\text { DIS - } \\
\text { SOLVED } \\
\text { (MG/L) }\end{array}$ & $\begin{array}{l}\text { HYDRO- } \\
\text { GEN } \\
\text { SULFIDE } \\
\text { TOTAL } \\
\text { (MG/L } \\
\text { AS H2S) }\end{array}$ & $\begin{array}{l}\text { ALKA- } \\
\text { LINITY } \\
\text { WAT WH } \\
\text { TOT FET } \\
\text { FIELD } \\
\text { MG/L AS } \\
\text { CACO3 }\end{array}$ & $\begin{array}{c}\text { ALKA - } \\
\text { LINITY } \\
\text { LAB } \\
\text { (MG/L } \\
\text { AS } \\
\text { CACO3) }\end{array}$ & $\begin{array}{c}\text { BICAR- } \\
\text { BONATE } \\
\text { WATER } \\
\text { WH FET } \\
\text { FIELD } \\
\text { MG/L AS } \\
\text { HCO3 }\end{array}$ \\
\hline $\begin{array}{c}\text { APR } 1976 \\
26 \text {. } \\
\text { AUG } 1996\end{array}$ & 0830 & 460 & $\cdots$ & $\cdots$ & $\cdots$ & -- & $\therefore$ & -- & $\cdots$ & - & 230 \\
\hline $07 \ldots$ & 1115 & 380 & 381 & 7.3 & 7.64 & 17.5 & 1.47 & $\cdots$ & 94 & 108 & - \\
\hline
\end{tabular}

\begin{tabular}{llllll}
\multicolumn{7}{c}{ HARD- } & & & \\
HARD - & NESS & & MAGNE- & & SODIUM \\
NESS & NONCARB & CALCIUM & SIUM, & SODIUM, & AD- \\
TOTAL & WH WAT & DIS- & DIS- & DIS- & SORP- \\
(MG/L & TOT FLD & SOLVED & SOLVED & SOLVED & TION \\
AS & MG/L AS & (MG/L & (MG/L & (MG/L & RATIO \\
CACO3) & CACO3 & AS CA) & AS MG) & AS NA) &
\end{tabular}

$\begin{array}{rcll} & & & \\ & \text { POTAS- } & \text { CHLO- } & \\ & \text { SIUM, } & \text { RIDE, } & \text { SULFATE } \\ & \text { DIS- } & \text { DIS- } & \text { DIS- } \\ & \text { SOLVED } & \text { SOLVED } & \text { SOLVED } \\ \text { SODIUM } & \text { (MG/L } & \text { (MG/L } & \text { (MG/L } \\ \text { PERCENT } & \text { AS K) } & \text { AS CL) } & \text { AS SO4) }\end{array}$

APR 1976

$26 \ldots$ AUG 1996

$07 . .$.

$\begin{array}{rrr}36 & \cdots & 5.1 \\ 130 & \cdots & 36\end{array}$

\begin{abstract}
$5.6 \quad 120$
$8.6 \quad 15$
\end{abstract}

\begin{abstract}
9
\end{abstract}
87

$2.1 \quad 9.6 \quad 79$

0.6

19

8. 317

39

DATE
APR 1976
$26 \ldots 96$
AUG 1996
$07 \ldots$

$\begin{array}{ll} & \\ \text { FLUO- } & \text { SILICA, } \\ \text { RIDE, } & \text { DIS- } \\ \text { DIS- } & \text { SOLVED } \\ \text { SOLVED } & \text { (MG/L } \\ \text { (MG/L } & \text { AS } \\ \text { AS F) } & \text { SIO2) }\end{array}$

NITRO-
GEN,
AMMONIA
DIS-
SOLVED
(MG/L
AS N)

NITRO-
GEN,

NITRO - NITRO - NITRO-

PHOS -

PHOS -

GEN, GEN, GEN, AM- GEN,

DIS - $\quad$ DIS - ORGANIC

$\begin{array}{lll}\text { SOLVED } & \text { SOLVED } & \text { DIS. } \\ \text { (MG/L } & \text { (MG/L } & \text { (MG/L }\end{array}$

(MG/L

(MG/L

NO2+NO3 -

SOLVED

PHATE, PHOS - PHORUS

ORTHO， PHORUS ORTHO

DIS - DIS - DIS -

SOLVED SOLVED SOLVED

$\begin{array}{lll}\text { (MG / L } & \text { (MG/L } & \text { (MG/L } \\ \text { AS PO4) AS P) AS P) }\end{array}$

$\begin{array}{ccccccc}0.50 & 10 & \ldots & <0.010 & 0.0 & \ldots & 1.00 \\ 0.70 & 9.2 & 0.040 & <0.010 & \ldots & <0.20 & 1.20\end{array}$

0.09

$-$

0.030

0.31

0.090

0.100

30 
WATER-QUALITY DATA

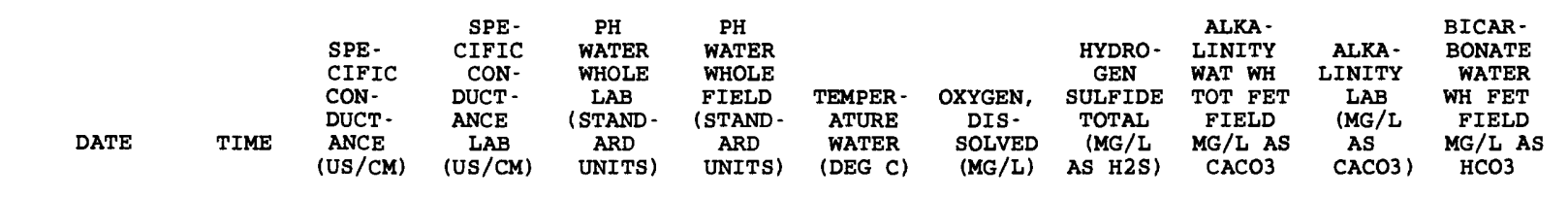

\begin{tabular}{|c|c|c|c|c|c|c|c|c|c|c|c|}
\hline $\begin{array}{l}\text { APR } 1976 \\
26 \ldots 9 \\
\text { AUG } 1996\end{array}$ & 1300 & 130 & $\cdots$ & $\cdots$ & $\cdots$ & 25.0 & $\cdots$ & $\cdots$ & 34 & $\cdots$ & 41 \\
\hline $15 \ldots$ & 1330 & 137 & 136 & 6.9 & 7.2 & 23.4 & 6.01 & $\cdots$ & 37 & 36 & - \\
\hline
\end{tabular}

\begin{tabular}{cccc} 
& \multicolumn{3}{c}{ HARD - } \\
& HARD - & NESS \\
& NESS & NONCARB & CALCIUM \\
& TOTAL & WH WAT & DIS- \\
& (MG/L & TOT FLD & SOLVED \\
DATE & AS & MG/L AS & (MG/L \\
& CACO3) & CACO3 & AS CA)
\end{tabular}

$\begin{array}{ccccccc}\text { MAGNE- } & & \text { SODIUM } & \text { POTAS- } & \text { CHLO- } \\ \text { SIUM, } & \text { SODIUM, } & \text { AD- } & & \text { SIUM, } & \text { RIDE, } & \text { SULFATE } \\ \text { DIS- } & \text { DIS- } & \text { SORP- } & & \text { DIS- } & \text { DIS- } & \text { DIS- } \\ \text { SOLVED } & \text { SOLVED } & \text { TION } & & \text { SOLVED } & \text { SOLVED } & \text { SOLVED } \\ \text { (MG/L } & \text { (MG/L } & \text { RATIO } & \text { SODIUM } & \text { (MG/L } & \text { (MG/L } & \text { (MG/L } \\ \text { AS MG) } & \text { AS NA) } & & \text { PERCENT } & \text { AS K) } & \text { AS CL) } & \text { AS SO4) }\end{array}$

APR 1976
$26 \%$
AUG 1996

15 ...

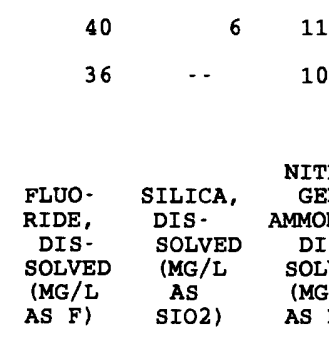

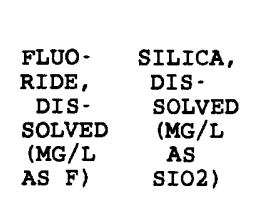

$$
2.9 \quad 7.1
$$

0.5

26

3.1

$0.80 \quad 19$

$2.7 \quad 9.5$

0.7

2.9

$1.1 \quad 21$

ATE

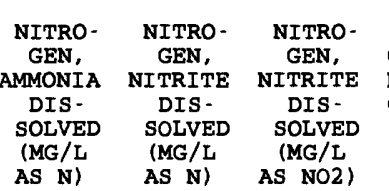

NITRO-
GEN, AM-
MONIA +
ORGANIC
DIS .
(MG/L
AS N)

NITRO-
GEN,
NO2+NO3
DIS-
SOLVED
(MG/L
AS N)

PHOS -

PHATE,

PHOS - PHORUS

, PHORUS ORTHO,

DIS - DIS - DIS -

SOLVED SOLVED SOLVED

(MG/L (MG/L (MG/L

APR 1976

26

AUG 199

$15 \ldots$

$$
\begin{array}{ll}
0.30 & 15 \\
0.30 & 16
\end{array}
$$

$\ldots \quad<0.010$

0.0

-

0.830

0.18

AS P)

AS P)

0.020

0.010

$0.03<0.20$

0.760

0.28

0.060

0.060

0.090

SOLIDS, SOLIDS,

AT 180 CONSTI -
DEG. C TUENTS,

SOLIDS, ALUM-

SOLIDS, ALUM- ANTI -

$\begin{array}{ll}\text { DIS - } & \text { DIS - } \\ \text { SOLVED } & \text { SOLVED }\end{array}$

SOLVED DIS -

SOLVED

SOLVED

(UG/L

ARSENIC BARIUM,

$\begin{array}{cc}\text { DIS - } & \text { DIS - } \\ \text { SOLVED } & \text { SOLVED }\end{array}$

$\begin{array}{lr}\text { SOLVED } & \text { SOLVED } \\ \text { (UG/L } & \text { (UG/L }\end{array}$

AS AS) AS BA)

LIUM,

DIS -

$\begin{array}{lll}\text { (UG/L } & \text { SOLVED } & \text { SOLVED } \\ \text { (MG/L } & \text { (UG/L }\end{array}$

(MG/L) (MG/L)

AC-FT) AS AL)

AS SB)

AS BE)

AS BR)

AS CD)

APR 1976

AUG 26 1966

15 ...

$\begin{array}{cc}- & 83 \\ 90 & 89\end{array}$

0.11

0.12

5

$<1$

6

200

-

$-$

2.0

CHRO- MIUM, COBALT, COPPER,

$\begin{array}{lcl}\text { DIS - } & \text { DIS - } & \text { DIS - } \\ \text { SOLVED } & \text { SOLVED } & \text { SOLVED }\end{array}$

(UG/L (UG/L (UG/L

AS CR) AS CO)

AS CU)

IRON,
DIS-
SOLVED
(UG/L
AS FE)

LEAD,
DIS-
SOLVED
(UG/L
AS PB)

MANGA -

$\begin{array}{ll}\text { MANGA - } & \text { MOLYB - } \\ \text { NESE, MERCURY DENUM, }\end{array}$

DIS - DIS -

SOLVED SOLVED

(UG/L (UG/L

DIS-
SOLVED

(UG/L

AS MO)

NICKEL, SILVER,

DIS - DIS -

SOLVED SOLVED

(UG/L (UG/L

AS NI) AS AG)

APR 1976

$26 \ldots$

AUG 1996

$15 .$. .

$\begin{array}{ll}\cdots & \cdots \\ <1 & <1\end{array}$

5
1

40

$9<1$
$<10<0.5$
$<1$

$<1$
2

$<1<1.0$

$\begin{array}{lcccc} & & & \text { RADIUM } & \text { GROSS } \\ \text { SELE- } & & \text { URANIUM } & 226, & \text { ALPHA, } \\ \text { NIUM, } & \text { ZINC, } & \text { NATURAL } & \text { DIS- } & \text { DIS- } \\ \text { DIS- } & \text { DIS- } & \text { DIS - } & \text { SOLVED, } & \text { SOLVED } \\ \text { SOLVED } & \text { SOLVED } & \text { SOLVED } & \text { RADON } & \text { (UG/L } \\ \text { (UG/L } & \text { (UG/L } & \text { (UG/L } & \text { METHOD } & \text { AS } \\ \text { AS SE) } & \text { AS ZN) } & \text { AS U) } & \text { (PCI/L) } & \text { U-NAT) }\end{array}$

$\begin{array}{lc}\text { GROSS } & \text { GROSS } \\ \text { BETA, } & \text { BETA, } \\ \text { DIS- } & \text { DIS- } \\ \text { SOLVED } & \text { SOLVED } \\ (\text { PCI/L } & (\text { PCI/L } \\ \text { AS SR/ } & \text { AS } \\ \text { Y-90) } & \text { CS-137) }\end{array}$
POTAS -
TOTAL
(PCI/L)

$\begin{array}{cc} & \text { TRITIUM } \\ & \text { 2 SIGMA } \\ \text { WATER, } \\ \text { TRITIUM } & \text { WHOLE, } \\ \text { TOTAL } & \text { TOTAL } \\ \text { (PCI/L) } & (\text { PCI/L) }\end{array}$

APR 1976
$26 \ldots 9$

AUG 159

$\begin{array}{rrc}1 & <20 & - \\ 1 & 2 & <1.0\end{array}$

\begin{abstract}
$4.7 \quad 3.6$
\end{abstract}

\begin{abstract}
$\begin{array}{ll}4.3 & 1.2 \\ \ldots & \ldots\end{array}$
\end{abstract}
5.4

1.9 


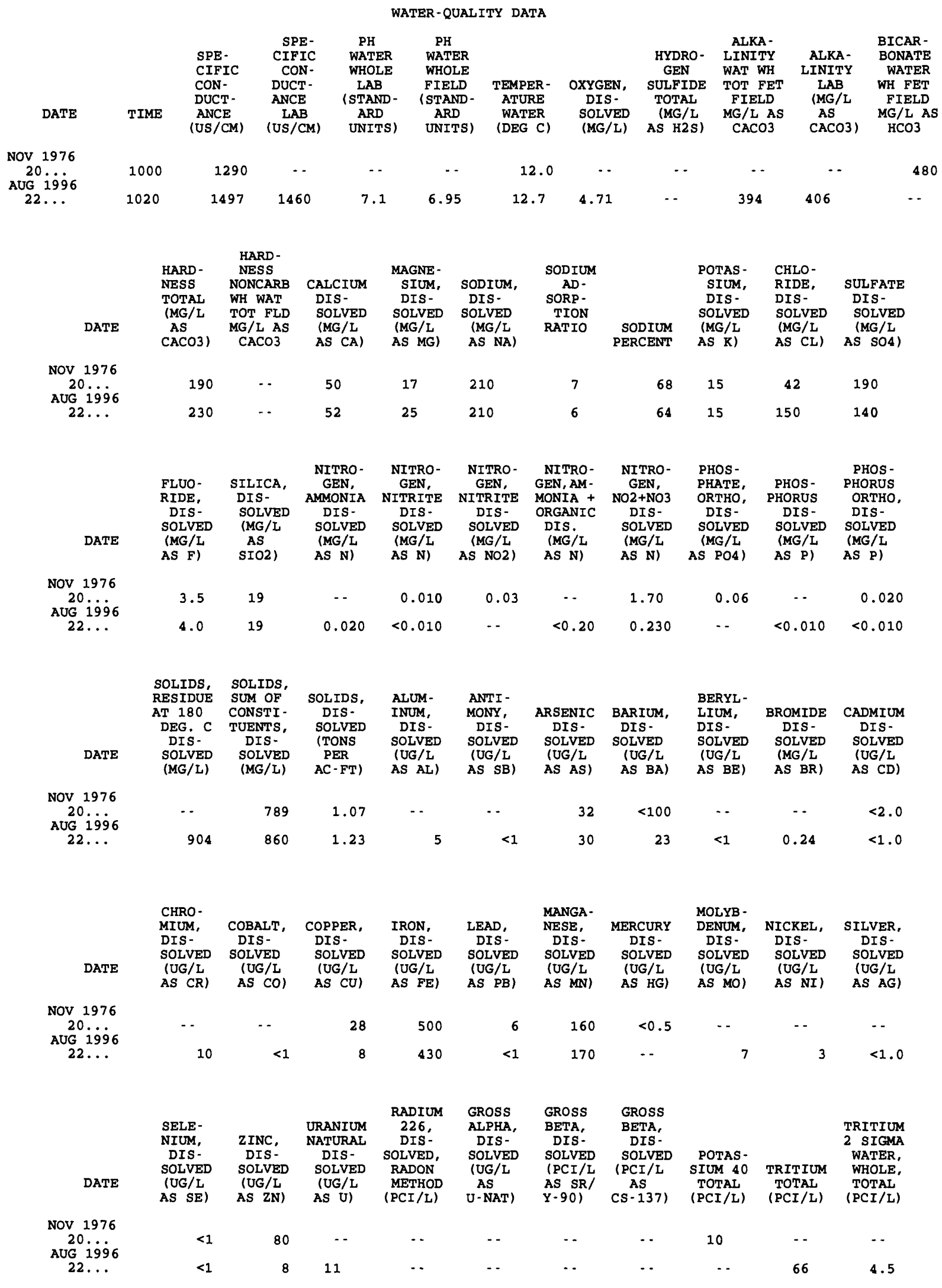


WATER-QUALITY DATA

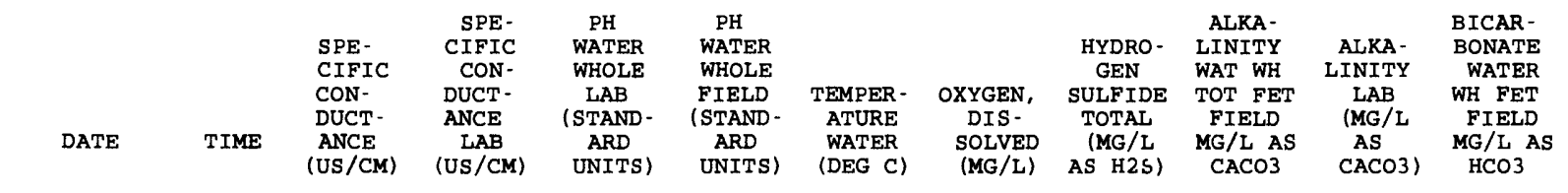

\section{JUL 1976 \\ SEP 1996 \\ $03 \ldots$}

$\begin{array}{ccc}0900 & 690 & \cdots \\ 1330 & 387 & 316\end{array}$

$\begin{array}{rrrrrrrr}- & \ldots & \ldots & \ldots & \ldots & 246 & \ldots & 300 \\ 6.9 & 6.54 & 17.1 & 6.13 & \ldots & 148 & 139 & \ldots\end{array}$

\begin{tabular}{|c|c|c|c|c|c|c|c|c|c|c|}
\hline DATE & $\begin{array}{l}\text { HARD - } \\
\text { NESS } \\
\text { TOTAL } \\
\text { (MG/L } \\
\text { AS } \\
\text { CACO3) }\end{array}$ & $\begin{array}{l}\text { HARD - } \\
\text { NESS } \\
\text { NONCARB } \\
\text { WH WAT } \\
\text { TOT FLD } \\
\text { MG/L AS } \\
\text { CACO3 }\end{array}$ & $\begin{array}{l}\text { CALCIUM } \\
\text { DIS- } \\
\text { SOLVED } \\
\text { (MG/L } \\
\text { AS CA) }\end{array}$ & $\begin{array}{l}\text { MAGNE- } \\
\text { SIUM, } \\
\text { DIS - } \\
\text { SOLVED } \\
\text { (MG/L } \\
\text { AS MG) }\end{array}$ & $\begin{array}{l}\text { SODIUM, } \\
\text { DIS- } \\
\text { SOLVED } \\
\text { (MG/L } \\
\text { AS NA) }\end{array}$ & $\begin{array}{l}\text { SODIUM } \\
\text { AD- } \\
\text { SORP- } \\
\text { TION } \\
\text { RATIO }\end{array}$ & $\begin{array}{l}\text { SODIUM } \\
\text { PERCENT }\end{array}$ & $\begin{array}{l}\text { POTAS - } \\
\text { SIUM, } \\
\text { DIS - } \\
\text { SOLVED } \\
\text { (MG/L } \\
\text { AS K) }\end{array}$ & $\begin{array}{l}\text { CHLO- } \\
\text { RIDE, } \\
\text { DIS - } \\
\text { SOLVED } \\
\text { (MG/L } \\
\text { AS CL) }\end{array}$ & $\begin{array}{l}\text { SULFATE } \\
\text { DIS- } \\
\text { SOLVED } \\
\text { (MG/L } \\
\text { AS SO4) }\end{array}$ \\
\hline $\begin{array}{l}\text { JUL } 1976 \\
21.29 \\
\text { SEP } 1996\end{array}$ & 300 & 57 & 85 & 22 & 41 & 1 & 23 & 2.2 & 38 & 46 \\
\hline DATE & $\begin{array}{l}\text { FLUO- } \\
\text { RIDE, } \\
\text { DIS- } \\
\text { SOLVED } \\
\text { (MG/L } \\
\text { AS F) }\end{array}$ & $\begin{array}{l}\text { SILICA, } \\
\text { DIS- } \\
\text { SOLVED } \\
\text { (MG/L } \\
\text { AS } \\
\text { SIO2) }\end{array}$ & $\begin{array}{c}\text { NITRO- } \\
\text { GEN, } \\
\text { AMMONIA } \\
\text { DIS- } \\
\text { SOLVED } \\
\text { (MG/L } \\
\text { AS N) }\end{array}$ & $\begin{array}{c}\text { NITRO- } \\
\text { GEN, } \\
\text { NITRITE } \\
\text { DIS- } \\
\text { SOIVED } \\
\text { (MG/L } \\
\text { AS N) }\end{array}$ & $\begin{array}{c}\text { NITRO- } \\
\text { GEN, } \\
\text { NITRITE } \\
\text { DIS- } \\
\text { SOLVED } \\
\text { (MG/L } \\
\text { AS NO2) }\end{array}$ & $\begin{array}{l}\text { NITRO- } \\
\text { GEN, AM- } \\
\text { MONIA + } \\
\text { ORGANIC } \\
\text { DIS. } \\
\text { (MG/L } \\
\text { AS N) }\end{array}$ & $\begin{array}{c}\text { NITRO- } \\
\text { GEN, } \\
\text { NO2+NO3 } \\
\text { DIS- } \\
\text { SOLVED } \\
\text { (MG/L } \\
\text { AS N) }\end{array}$ & $\begin{array}{c}\text { PHOS- } \\
\text { PHATE, } \\
\text { ORTHO, } \\
\text { DIS- } \\
\text { SOLVED } \\
\text { (MG/L } \\
\text { AS PO4) }\end{array}$ & $\begin{array}{c}\text { PHOS- } \\
\text { PHORUS } \\
\text { DIS - } \\
\text { SOLVED } \\
\text { (MG/L } \\
\text { AS P) }\end{array}$ & $\begin{array}{c}\text { PHOS - } \\
\text { PHORUS } \\
\text { ORTHO, } \\
\text { DIS- } \\
\text { SOLVED } \\
\text { (MG/L } \\
\text { AS P) }\end{array}$ \\
\hline $\begin{array}{l}\text { JUL } 1976 \\
21 \ldots \\
\text { SEP } 1996 \\
03 \ldots\end{array}$ & 0.30 & 26 & 0.060 & $<0.010$ & 0.0 & $<0,20$ & 11.0 & 0.12 & $<0,010$ & 0.040 \\
\hline DATE & $\begin{array}{l}\text { SOLIDS, } \\
\text { RESIDUE } \\
\text { AT } 180 \\
\text { DEG. C } \\
\text { DIS - } \\
\text { SOLVED } \\
\text { (MG/L) }\end{array}$ & $\begin{array}{c}\text { SOLIDS, } \\
\text { SUM OF } \\
\text { CONSTI - } \\
\text { TUENTS, } \\
\text { DIS - } \\
\text { SOLVED } \\
\text { (MG/L) }\end{array}$ & $\begin{array}{c}\text { SOLIDS, } \\
\text { DIS- } \\
\text { SOLVED } \\
\text { (TONS } \\
\text { PER } \\
\text { AC-FT) }\end{array}$ & $\begin{array}{l}\text { ALUM - } \\
\text { INUM, } \\
\text { DIS - } \\
\text { SOLVED } \\
\text { (UG/L } \\
\text { AS AL) }\end{array}$ & $\begin{array}{l}\text { ANTI - } \\
\text { MONY, } \\
\text { DIS - } \\
\text { SOLVED } \\
\text { (UG/L } \\
\text { AS SB) }\end{array}$ & $\begin{array}{c}\text { ARSENIC } \\
\text { DIS- } \\
\text { SOLVED } \\
\text { (UG/L } \\
\text { AS AS) }\end{array}$ & $\begin{array}{l}\text { BARIUM, } \\
\text { DIS- } \\
\text { SOLVED } \\
\text { (UG/L } \\
\text { AS BA) }\end{array}$ & $\begin{array}{l}\text { BERYL- } \\
\text { LIUM, } \\
\text { DIS - } \\
\text { SOLVED } \\
\text { (UG/L } \\
\text { AS BE) }\end{array}$ & $\begin{array}{c}\text { BROMIDE } \\
\text { DIS- } \\
\text { SOLVED } \\
\text { (MG/L } \\
\text { AS BR) }\end{array}$ & $\begin{array}{l}\text { CADMIUM } \\
\text { DIS- } \\
\text { SOLVED } \\
\text { (UG/L } \\
\text { AS CD) }\end{array}$ \\
\hline $\begin{array}{l}\text { JUL } 1976 \\
21 \ldots \\
\text { SEP } 1996 \\
03 \ldots\end{array}$ & 178 & 457 & 0.62 & $\cdots$ & $\cdots$ & 1 & $<100$ & $\cdots$ & 0.060 & $\begin{array}{r}2.0 \\
<1.0\end{array}$ \\
\hline DATE & $\begin{array}{l}\text { CHRO- } \\
\text { MIUM, } \\
\text { DIS- } \\
\text { SOLVED } \\
\text { (UG/L } \\
\text { AS CR) }\end{array}$ & $\begin{array}{l}\text { COBALT, } \\
\text { DIS- } \\
\text { SOLVED } \\
\text { (UG/L } \\
\text { AS CO) }\end{array}$ & $\begin{array}{l}\text { COPPER, } \\
\text { DIS- } \\
\text { SOLVED } \\
\text { (UG/L } \\
\text { AS CU) }\end{array}$ & $\begin{array}{l}\text { IRON, } \\
\text { DIS- } \\
\text { SOLVED } \\
\text { (UG/L } \\
\text { AS FE) }\end{array}$ & $\begin{array}{l}\text { LEAD, } \\
\text { DIS- } \\
\text { SOLVED } \\
\text { (UG/L } \\
\text { AS PB) }\end{array}$ & $\begin{array}{l}\text { MANGA - } \\
\text { NESE, } \\
\text { DIS- } \\
\text { SOLVED } \\
\text { (UG/L } \\
\text { AS MN) }\end{array}$ & $\begin{array}{c}\text { MERCURY } \\
\text { DIS- } \\
\text { SOLVED } \\
\text { (UG/L } \\
\text { AS HG) }\end{array}$ & $\begin{array}{l}\text { MOLYB - } \\
\text { DENUM, } \\
\text { DIS - } \\
\text { SOLVED } \\
\text { (UG/L } \\
\text { AS MO) }\end{array}$ & $\begin{array}{l}\text { NICKEL, } \\
\text { DIS- } \\
\text { SOLVED } \\
\text { (UG/L } \\
\text { AS NI) }\end{array}$ & $\begin{array}{c}\text { SILVER, } \\
\text { DIS - } \\
\text { SOLVED } \\
\text { (UG/L } \\
\text { AS AG) }\end{array}$ \\
\hline $\begin{array}{c}\text { JUL } 1976 \\
21 \ldots \\
\text { sEP } 1996 \\
03 \ldots\end{array}$ & $\cdots$ & $<1$ & 13 & 5400 & $<1$ & $\begin{array}{l}<10 \\
250\end{array}$ & $<0.5$ & $<1$ & 1 & $<1.0$ \\
\hline DATE & $\begin{array}{l}\text { SELE- } \\
\text { NIUM, } \\
\text { DIS - } \\
\text { SOLVED } \\
\text { (UG/L } \\
\text { AS SE) }\end{array}$ & $\begin{array}{l}\text { ZINC, } \\
\text { DIS- } \\
\text { SOLVED } \\
\text { (UG/L } \\
\text { AS ZN) }\end{array}$ & $\begin{array}{c}\text { URANIUM } \\
\text { NATURAL } \\
\text { DIS- } \\
\text { SOLVED } \\
\text { (UG/L } \\
\text { AS U) }\end{array}$ & $\begin{array}{c}\text { RADIUM } \\
226, \\
\text { DIS- } \\
\text { SOLVED, } \\
\text { RADON } \\
\text { METHOD } \\
\text { (PCI/L) }\end{array}$ & $\begin{array}{l}\text { GROSS } \\
\text { ALPHA, } \\
\text { DIS - } \\
\text { SOLVED } \\
\text { (UG/L } \\
\text { AS } \\
\text { U-NAT) }\end{array}$ & $\begin{array}{l}\text { GROSS } \\
\text { BETA, } \\
\text { DIS - } \\
\text { SOLVED } \\
(P C I / L \\
\text { AS SR/ } \\
\text { Y } 90)\end{array}$ & $\begin{array}{c}\text { GROSS } \\
\text { BETA, } \\
\text { DIS- } \\
\text { SOLVED } \\
\text { (PCI/L } \\
\text { AS } \\
\text { CS-137) }\end{array}$ & $\begin{array}{l}\text { POTAS- } \\
\text { SIUM } 40 \\
\text { TOTAL } \\
\text { (PCI/L) }\end{array}$ & $\begin{array}{l}\text { TRITIUM } \\
\text { TOTAL } \\
\text { (PCI/L) }\end{array}$ & $\begin{array}{c}\text { TRITIUM } \\
2 \text { SIGMA } \\
\text { WATER, } \\
\text { WHOLE, } \\
\text { TOTAL } \\
\text { (PCI/L) }\end{array}$ \\
\hline $\begin{array}{l}\text { JUL } 1976 \\
21 \ldots \\
\text { SEP } 1996\end{array}$ & 4 & 30 & $\cdots$ & $\cdots$ & 3.6 & $<12$ & 4.3 & 1.6 & - & $\cdots$ \\
\hline $03 \ldots$ & $<1$ & 32 & $<1.0$ & $\cdots$ & $\cdots$ & $\cdots$ & $\cdots$ & $\cdots$ & 86 & 5.8 \\
\hline
\end{tabular}






